WIDER Working Paper 2020/166

Vulnerable employment of Egyptian, Jordanian, and Tunisian youth

Trends and determinants

Shireen AlAzzawi ${ }^{1}$ and Vladimir Hlasny ${ }^{2}$

December 2020 
Abstract: Youths in the Middle East and North Africa face the highest unemployment rates in the world. Those who are employed are pushed to accept informal sector jobs that are insecure, unsafe, and lack non-wage benefits. Precarious employment is pervasive among lower socioeconomic groups, leading to the perpetuation of misery across generations. Understanding employment outcomes therefore requires a broad focus encompassing the access to decent work, the evolution in this access over time, and the initial conditions. We analyse the static nature of vulnerable employment - especially youth unemployment and informality-and workers' transitions to decent work using multinomial logistic regressions and recent Labour Market Panel Surveys for Egypt, Jordan, and Tunisia. We find growing trends of vulnerable employment, particularly for youth cohorts. Especially in Egypt and Tunisia, children of poorer and lesseducated parents start out in vulnerable jobs and are unlikely to ever attain formal employment. Wealth effects follow them throughout their careers.

Key words: vulnerable employment, informality, youth unemployment, Middle East and North Africa, multinomial logistic regressions

JEL classification: J21, J46, J62, N35

Tables and figures: at the end of the paper

\footnotetext{
${ }^{1}$ Economics Department, Leavey School of Business, Santa Clara University, Santa Clara, CA, USA, corresponding author: salazzawi@scu.edu; ${ }^{2}$ Economics Department, Ewha Womans University, Seoul, Korea

This study has been prepared within the UNU-WIDER project Transforming informal work and livelihoods.

Copyright (C) UNU-WIDER 2020

Information and requests: publications@wider.unu.edu

ISSN 1798-7237 ISBN 978-92-9256-923-5

https://doi.org/10.35188/UNU-WIDER/2020/923-5

Typescript prepared by Lesley Ellen.
}

United Nations University World Institute for Development Economics Research provides economic analysis and policy advice with the aim of promoting sustainable and equitable development. The Institute began operations in 1985 in Helsinki, Finland, as the first research and training centre of the United Nations University. Today it is a unique blend of think tank, research institute, and UN agency — providing a range of services from policy advice to governments as well as freely available original research.

The Institute is funded through income from an endowment fund with additional contributions to its work programme from Finland, Sweden, and the United Kingdom as well as earmarked contributions for specific projects from a variety of donors.

Katajanokanlaituri 6 B, 00160 Helsinki, Finland

The views expressed in this paper are those of the author(s), and do not necessarily reflect the views of the Institute or the United Nations University, nor the programme/project donors. 
Youths in the Middle East and North Africa (MENA) face notoriously precarious employment prospects. Youth unemployment there is the highest in the world, at 23 per cent in Arab states and 30 per cent in Northern Africa in 2019. ${ }^{1}$ Youth unemployment in the Arab states was also the fastest growing in the world, increasing from 19.5 to 23 per cent between 2012 and 2020. ${ }^{2}$ Unemployment among young women in the region is more than twice that of young men, reaching 42 per cent, and has been growing at a much faster rate than that of young men (ILO 2020b).

While youth unemployment is a major problem in the region, a more alarming issue is that even those who are employed tend to work in vulnerable jobs that are informal, lacking job security and stability, paid leave, social and health insurance, and safety (WEF 2012). The share of youth in informal employment is as high as 85 per cent in Arab states ( 87.5 per cent in Northern Africa), far higher than that for adults (61 per cent) (ILO 2020a). Arab states have the highest youth-adult gap in the world in terms of informal employment, which reflects the worsening labour market conditions available to youths compared to older cohorts. Such vulnerabilities are often closely associated with, and reinforce, multiple dimensions of social and economic deprivation, as well as entrenched inequality of opportunity and income, and may persist across generations.

There are a number of well-known structural faults in the MENA region's labour markets that stem primarily from the strong state of duality between 'good' formal jobs, in both the public and private sectors, and 'bad' informal jobs. This duality is a direct result of the state-led industrialization model that existed in the 1950s through the 1970s in most of these economies. This contract started to fray and disappear by the 1980s, following exchange rate and budget crises that forced most of these economies to move towards neoliberal economic development. The availability of formal public-sector jobs gradually declined over the next several decades without a parallel increase in formal private-sector jobs, leaving new labour market entrants at a considerable disadvantage compared to older cohorts (Assaad 2014). In Egypt, Jordan, and Tunisia, for example, job creation and access to formal jobs have all deteriorated over the last several decades, while the share of irregular wage work has increased (Assaad and Krafft 2015; Assaad and Salemi 2019; Shahen et al. 2020).

Restrictive employment contract laws and high ratios of formal minimum wages to mean wages in some MENA countries push down labour demand and are harmful to employment (Agénor et al. 2004). At the same time, the large pool of unemployed workers aspiring to formal jobs empowers large corporate employers to exert power over their hiring, restraining employment. Recent studies for Egypt and Jordan have concluded that the type of higher education, a measure of human capital and skill, has a lower effect on the employers' choice of the limited number of hires from large applicant pools than circumstances such as background and social class (Assaad et al. 2018; Krafft and Assaad 2016). The aspiration of attaining a public-sector job discourages young MENA workers of higher socio-economic standing from considering lower-quality jobs (Assaad et al. 2010; Egel and Salehi-Isfahani 2010). By contrast, those without the advantage of connections must make do with informal and irregular private-sector jobs, or are forced to migrate to sustain their livelihoods (Binzel 2011; Hlasny and AlAzzawi 2018).

\footnotetext{
${ }^{1}$ The ILO defines 'Arab states' as consisting of the Arab countries in Asia and reports separate statistics for North African Arab countries.

${ }^{2}$ Youth unemployment in Northern Africa stayed almost the same between 2012 and 2020 (ILO 2020a).
} 
International development agencies, such as the World Bank, International Labour Organization, and United Nations Development Programme, have long recognized the value of accounting for work status within employment. When most jobs available to a particular group are irregular jobs, members of the group face a higher level of instability and risk in various aspects of their lives. It is therefore crucial to study the prevalence of such vulnerable jobs and their evolution over time.

In this paper, we contribute to the literature by examining the prevalence, incidence, and evolution of vulnerable employment in three MENA countries-Egypt (1998, 2006, 2012, 2018), Jordan (2010-16), and Tunisia (2014)—during periods of far-reaching economic and social change. ${ }^{3} \mathrm{We}$ utilize panel labour market data spanning 20 years in Egypt (from the Egypt Labour Market Panel Survey (ELMPS) for the years 1998, 2006, 2012, and 2018), six years in Jordan (from the Jordan Labour Market Panel Surveys (JLMPS) for 2010 and 2016), and retrospective labour market data for Tunisia (from the Tunisian Labour Market Panel Survey (TLMPS) for 2014) (OAMDI 2019).

In Egypt, the period under study was initially characterized by a strong push toward economic reform, trade opening, and privatization of publicly owned firms, followed by the 2008 economic crisis and a surge of popular discontent leading to the 2011 uprising and the 2011-14 political changes. The 2018 survey followed a series of significant currency devaluations in January 2013, March 2016, and notably November 2016, which hit the most vulnerable households particularly hard (AlAzzawi and Hlasny 2019a). In Jordan, the period under study started with widespread discontent due to worsening living conditions and spans the post-Arab Spring period and civil war in Syria when Jordan absorbed a large fraction of refugees, representing a sizeable shock to its labour market. In Tunisia, the period under study is in the immediate aftermath of the Jasmine revolution in the winter of 2010-11, at a time when the political situation had largely stabilized and the economy was steadily growing, raising the hope that youth employment prospects would improve (Stampini and Verdier-Chouchane 2011).

These data allow both static and dynamic analysis of workers' vulnerability at multiple points in their careers and enable us to differentiate between cohorts by age and gender. We are able to follow the same individuals over time, examining the dynamics of starting out in a vulnerable job and the prospects of eventually exiting into a decent job.

The rest of the paper is organized as follows. We first review relevant literature, data sources, and concept definitions in Sections 2 and 3. Section 4 describes the empirical approaches taken to isolate the driving factors of individuals' employment vulnerability and employment mobility, directly followed by the presentation of our findings. Section 5 reiterates the key conclusions and policy implications.

\section{Existing evidence}

The unemployment rate among MENA region youths is the highest and fastest growing relative to other world regions (Pieters 2013). Kabbani and Kothari (2005) confirmed that MENA region youths faced poor employment prospects, and that societal and enterprise social norms and childbearing breaks from the labour market contributed to the particularly precarious conditions

\footnotetext{
${ }^{3}$ This paper is an extension of our previous Economic Research Forum working paper (AlAzzawi and Hlasny 2018) by extending the analysis to an additional country (Tunisia) and adding results for the most recent data for Egypt (2018). In addition, it utilizes different definitions of youth and non-youth, and extends the static and dynamic analysis in several dimensions.
} 
for women. More recent research has relied on survey microdata to assess the outcomes of various social groups. Majbouri (2017) contrasted mobility in expenditures per capita in Egypt and Jordan and found mobility in Egypt to be low in absolute terms as well as compared to Jordan.

Assaad and Krafft (2015) used ELMPS 1998-2012 data to assess labour market conditions for workers of all ages. They identified large differences in working conditions, job stability, and risk of falling into poverty across workers of different employment types. Irregular workers were among the most vulnerable. Assaad and Krafft (2014) analysed youth workers' transitions from school to the labour market. Workers' employment prospects were found to be constrained by non-meritocratic recruiting practices by employers and a skills mismatch. Women's personal circumstances, such as family resources and childbearing plans, also affected their labour market achievements.

Public-sector jobs have diminished in recent years as the main employment type in Egypt and Tunisia, signalling the governments' efforts to reform and rewrite the social contract in light of economic challenges (El-Haddad 2020). At the same time, private-sector positions have become less likely to confer benefits and contracts (Amer 2012, 2015; Assaad 2012). The prospect of public-sector employment is particularly low among Egyptian youths, as the legal age for hiring in the public sector has increased and employers have been explicitly encouraged to hire older workers. The role of connections in securing public-sector jobs in Egypt has also grown since the 1990s for both men and women (Barsoum and Abdalla 2020).

In Jordan, young workers are highly immobile and unable to transition from informal to formal jobs, although they can move between formal private- and public-sector jobs. Jordanian women are particularly vulnerable because of the diminishing public-sector employment, lack of accommodation for their needs in private-sector jobs, and sluggish reform of labour laws (Assaad et al. 2014; Mryyan 2012). The share of youths not in employment, education, or training is high compared to developing countries in other world regions for both sexes but particularly for females (Pieters 2013). Meanwhile, vulnerability in employment has various socio-economic repercussions for the MENA region, including for youths' economic wellbeing, marriage prospects, education, mental health, and the prevalence of conflict and violence (Ehab 2019; Fehling et al. 2016).

Our study contributes by examining the drivers of vulnerable employment among young workers, and their prospects for job mobility. We assess the impact of workers' circumstances and labour market experience on their wage earnings, their prospect of attaining a decent first job, and their prospect of attaining better jobs in the following years. Multiple waves of high-quality panel surveys for Egypt (four waves) and Jordan (two waves), and one wave for Tunisia are used to gauge workers' circumstances, follow the outcomes of workers over time, and link the outcomes of fathers to those of their offspring. To our knowledge, this is the only study that examines the dynamics of vulnerable employment among MENA youths.

The findings from our vulnerability and mobility analysis can inform us about how hard it is to escape a vulnerable position as measured by employment status, work conditions, and earnings, or to advance to a 'decent' job when workers start out in a 'poor quality' job. Our findings also underline the importance of initial family circumstances in determining lifetime opportunities and point to the strong persistence of intergenerational misery. Our findings can help guide policy recommendations regarding the targeting of employment vulnerability using specific policy tools. 
Our data are from the 1998, 2006, 2012, and 2018 waves of the ELMPS, the 2010 and 2016 waves of the JLMPS, and the 2014 TLMPS. These high-quality representative labour market surveys were conducted, harmonized, and made available by the Economic Research Forum (ERF) (OAMDI 2019). These data are ideal for our analysis as they cover workers' labour earnings, occupation, education, household assets, various demographics, and linked information about their fathers.

\subsection{Employment vulnerability}

Youth unemployment is high in the MENA overall but, at the same time, only those who receive support from family or the government can afford to remain unemployed. The first task of this study is to identify measures that capture the monetary and non-monetary aspects of workers' vulnerability in the labour market. Using the panel dimension of our surveys, we compare youth and non-youth workers in the initial period, and how their outcomes evolved in later years.

We classify workers as vulnerably employed if they engage in unpaid family work, self-employment (without employing others), irregular wage work, or informal private-sector work. These workers share undesirable working conditions including a lack of contracts, lack of benefits, low job security, and a lack of any form of social protection from shocks. ${ }^{4}$

Our analysis distinguishes between youth (aged 15-29) ${ }^{5}$ and non-youth workers (aged 30-59) and follows the respective groups across ranges of years. The 1998 cohort of Egyptian workers are followed over eight years, to 2006 (when the youths were 23-37 years of age); after another six years, to 2012 (when they were 29-43); and after another six years, to 2018 (when they were 3549). We therefore follow the '1998 youths' over an extensive part of their careers. We follow the '2006 Egyptian youths' across six years, to 2012, when they were 21-35, and to 2018, when they were 27-41. The '2012 Egyptian youths' are followed to 2018, when they were 21-35. We also follow the '2010 Jordanian youths' over the next six years, to 2016, when they were 21-35. The comparison group encompasses those aged 30-59 in each survey wave, who are followed across six years in Jordan, and up to 20 years in Egypt.

Vulnerable employment increased steadily in Egypt over time, from 16.5 per cent among all age groups in 1998 to 22.0 per cent in 2006, 23.8 per cent in 2012, and 27.8 per cent in 2018. In Jordan, by contrast, employment vulnerability fell from 12.6 per cent in 2010 to 8.6 per cent in 2016 . Finally, the Tunisian experience has been somewhere in-between, with 17.9 per cent of the workforce in vulnerable employment.

Vulnerable employment among youths was especially high in most of the years studied, particularly by the usual employment definition. ${ }^{6}$ Youths who started out in vulnerable employment also had

\footnotetext{
${ }^{4}$ The World Bank (2020) defines the vulnerably employed group as the sum total of unpaid family workers and the self-employed. This is a lower bound of our definition. Danquah et al. (2019), addressing informal employment, included all irregular, unpaid, and self-employment, notably excluding self-employment in registered businesses. As we acknowledge, however, business registration information is not available in our datasets. Moreover, the bulk of self-employment in the MENA region is deemed to be precarious, so this study considers all the self-employed (without employing others) to be vulnerable.

${ }^{5}$ We extend the age of youths to encompass workers who were 15-29 instead of the traditional 15-24. Many youths are students or military draftees till their early twenties. Restricting the age to below 24 would disregard the working status of these youths.

${ }^{6}$ 'Usual employment' refers to employment in a three-month reference period; 'current employment' refers to a oneweek span.
} 
a particularly low likelihood of transitioning to decent work later. Youths with vulnerable employment in 1998 were more than twice as likely as non-youths to keep their vulnerable status in 2006 (27.3 vs. 13.9 per cent), in 2012 (28.0 vs. 13.9 per cent), and in 2018 (28.4 vs. 14.2 per cent) (Panels 2-4 of Appendix Table A1a). Similarly, during 2006-18, while only 18.6-19.0 per cent of older workers who started out vulnerably employed stayed so, the likelihood of youth workers remaining vulnerable in 2012 was 29.7-30.3 per cent, and 31.1 per cent in 2018, compared to 18.9 per cent for non-youths (Table A1b). While 22.9 per cent of non-youths with vulnerable employment in 2012 stayed vulnerable in 2018, there was a 30.1 per cent likelihood of vulnerably employed youths remaining vulnerable in 2018 (Table A1c).

For Jordan, we found minor differences between youths and non-youths and over time. Limiting our analysis to Jordanian nationals, we saw that youths were higher educated than non-youths. Nevertheless, their unemployment rate was three times as high as that of non-youths (Tables A1de). The unemployed share also rose among youths over the 2010-16 period. The share of vulnerable employment was similar among youths and non-youths, but the share of those employed dropped dramatically among youths over time, from 47.7 per cent in 2010 to 37.1 per cent in 2016. Youths were thus less likely to accept vulnerable jobs and tended to remain unemployed or become inactive if decent jobs were unavailable. Nevertheless, we still found that youth workers were less likely to transition out of vulnerability. While 8.5-9.5 per cent of nonyouth workers who were initially in vulnerable positions in 2010 remained so in 2016, the share of youth workers who stayed vulnerable in 2016 was $9.5-10.8$ per cent.

In Tunisia, as in Jordan, youths were clearly better educated than non-youths, but they were less likely to be employed, and their unemployment rate was 14.8 per cent compared to 2 per cent for non-youths (Table A1f). The share of vulnerable employment was similar for both age groups suggesting that, as in Jordan, youths were less predisposed to taking vulnerable employment, and kept searching for better jobs.

\section{$4 \quad$ Main analysis and results}

Given the general trends in employment between the two age groups and across the three countries, the following sections appraise workers' employment status and mobility in detail and estimate the bearing of workers' circumstances on these outcomes. The corresponding analytical approaches are briefly introduced in each section, followed directly by a discussion of their results.

\subsection{Static analysis of employment status and vulnerability}

Our first analysis concerns workers' current employment sector, distinguishing youth versus older cohorts, and males versus females. This analysis encompasses those who were unemployed and those out of the labour force as these statuses are particularly prevalent among women (see Figures A1a-d for Egyptian youth in 1998-2018, A2a-b for Jordan, A2c for Tunisia). In Egypt, as of 1998, data frequencies reveal that more than 40 per cent of non-youth males were employed in the public sector, approximately 15 per cent were employers, and 10 per cent were in the formal private sector. A relative minority of non-youths, under 25 per cent, were vulnerably employed. By contrast, youth workers were predominantly employed in the informal private sector, followed by those doing unpaid family work and irregular wage work. Youth workers had a low prospect of attaining formal sector jobs. Unemployment rates among male youths were also higher-15 per cent for male youth workers compared to less than 5 per cent for those who were older. 
Egyptian women of any age had bleaker prospects still. The majority were out of the labour force. Older females (aged 30 to 59) were either in formal public-sector jobs or were inactive. Female youths had an even lower prospect of obtaining decent public-sector employment and therefore disproportionally remained out of the labour force. The female unemployment rate was higher, suggesting that the young women who might still be unmarried were likely to be job hunting but were only interested in the desirable public-sector positions that were becoming difficult to find.

The Egyptian surveys show that, during 2006-18, vulnerable employment became more prevalent among male youths. In 2006, over a quarter of them accepted informal private-sector jobs, while an additional 30 per cent ended up in other vulnerable types of jobs including unpaid family work, self-employment, and irregular wage work. Under 20 per cent of young men had a formal job as of 2006. Non-youth workers also faced deteriorating labour market conditions, as their access to formal public- and private-sector employment fell somewhat compared to 1998.

In 2012, only about 30 per cent of non-youths had formal public-sector jobs, while the share for youths had fallen to under 10 per cent. By 2018, the situation had continued to deteriorate, with the informal private sector now absorbing the majority of the youths and, together with the selfemployed, unpaid family workers, and irregular wage workers, accounted for over 55 per cent of youth employment. Among non-youth workers, public- and private-sector formal jobs jointly constituted only about 35 per cent of employment, while informal, irregular wage work, selfemployment, and unpaid family work accounted for 47 per cent of their employment, for the first time exceeding that of formal employment for non-youths.

A slightly better employment picture emerges in Jordan (Figures A2a-b). In the 2010 survey, approximately 50 per cent of non-youth men held formal jobs, few held irregular wage work, and approximately 25 per cent were self-employed, unpaid family workers, or informal private-sector workers. Male youths in Jordan fared better than Egyptian youths and even somewhat better than Jordanian non-youths. As in Egypt, most Jordanian women were out of the labour force or were formally employed.

In 2016, a region-wide crisis bore down on Jordanian workers, and 2.5 to 3 times more men exited the labour force compared to 2010. The unemployment rate among the Jordanian youth surged. The main employment type for both age groups was still formal employment, but fewer informal private-sector jobs were available to youths, evidently displaced by migrant workers and refugees. Most women remained out of the labour force, as in 2010. These findings corroborate evidence in prior studies that Jordanian male youths lack access to decent jobs and that the opportunities among females are poorer still (Amer 2012; Assaad 2012; Assaad et al. 2014; Mryyan 2012).

In Tunisia (Figure A2c), as of 2014, youths were substantially more likely to be unemployed than to be informally/irregularly employed, compared to both Egypt and Jordan: 28 per cent were unemployed and 18 per cent were out of the labour force, while only 20 per cent held formal private- or public-sector jobs. Among non-youth males, 40 per cent held formal jobs. The share of informal employment fell across workers' ages (as noted by El-Mekkaoui and Chaker 2020), but vulnerable employment taken together was similar for youths and non-youths. This is because a notable number of workers shifted from informal employment in their youth $(10$ per cent of youths, 17 per cent of non-youths) to self-employment in later years (15 per cent of youths, 10 per cent of non-youths). Females in Tunisia were largely discouraged from engaging in the labour market - 60 per cent of youths and 80 per cent of non-youths were out of the labour force. Only 15 per cent of women of all ages were able to find formal employment, while another 10 per cent accepted vulnerable jobs. While 20 per cent of female youths continued searching for work, fewer than 5 per cent of older females were doing so. 
In Table $1 \mathrm{a}$, we present the mean monthly earnings of workers in each employment status for youths and non-youths. Clearly, vulnerable employment categories are also disadvantaged in terms of earnings and there is a large gap between youths and non-youths in every employment status.

\subsection{Dynamic analysis of employment outcomes}

Next, cross-tabulations between two sets of outcomes allow us to gauge workers' performance as a function of their pre-existing circumstances. Workers' current employment status is linked to their past employment status (Figure 1), as well as to their household wealth (Figure 2) and parents' education (Figure 3).

Figure 1 reports the employment transitions for 1998 Egyptian male youths in the year 2006 (Figure 1i), 2006 male youths in 2012 (Figure 1ii), and 2012 male youths in 2018 (Figure 1iii). Figure 1iv shows this for 2010 Jordanian male youths in $2016 .^{7}$ The results for Egypt (Figures 1iiii) show very weak intertemporal mobility to formal public- or private-sector jobs. Between 56 and 68 per cent of those in vulnerable employment in 1998 remained so by 2006. At the same time, 66-88 per cent of those who started in formal jobs in 1998 had kept them in 2006. With the benefit of hindsight, young graduates in 1998 who aspired to eventually find decent work would have been advised to hold out in their search of formal jobs- that is, if they had the luxury of choice. By remaining unemployed or out of the labour force, they had a 19-29 per cent probability of finding formal jobs by 2006, compared to an 18-23 per cent probability if they had accepted informal work in 1998.

Between 2006 and 2012, the prospect of transitioning from an informal job to a formal job was similarly slim (10-21 per cent) and even lower than among the unemployed or economically inactive workers (19-31 per cent). At the same time, the prospect of formal-job workers keeping their status was high (59-82 per cent). Between 2012 and 2018, the situation deteriorated even further, with over 75 per cent of those who started out in 2012 in a vulnerable job unable to exit it by 2018 and, even more alarming, over 40 per cent ( 65 per cent) of those who had formal private jobs (were employers) in 2012 had moved to vulnerable jobs by 2018. The prospect of transitioning from informal to formal jobs was somewhat higher during 1998-2006 than during 2006-12. It declined once again during 2006-18.

Figure 1iv reports the transitions for Jordanian male youths during 2010-16. These youths were substantially more likely to move to formal positions during 2010-16 than Egyptian youths across all years. Fewer than 40 per cent of Jordanians started out in vulnerable jobs, while more than 60 per cent of Egyptians did so across all the years considered. Many Jordanians, however, chose unemployment or an inactive status in 2016 rather than accepting vulnerable positions. This reflected the growing tightness and instability in labour markets as a result of competition from migrant workers and refugees. Even though Egyptian youths were worse off in terms of being stuck in vulnerable jobs, Jordanians were forced out of the labour force entirely instead of holding on to precarious employment. At the same time, almost 70 per cent of formally employed workers in 2010 kept their formal status in 2016.

Only one survey wave is available for Tunisia (Figure 1v), but this survey contains retrospective questions regarding workers' employment and student status in 2011. Tunisian youths were as unlikely to move to formal jobs during 2011-14 as Egyptians during 2006-12. Of the 46 per cent of Tunisian young men who started in vulnerable jobs over this period, only 15 per cent moved

\footnotetext{
${ }^{7}$ Appendix Figure A3 shows longer-term transitions for Egyptian youths from when they were in employment in 1998 to 2012 and 2018, and for those who were in employment in 2006 to 2018.
} 
on to formal private- or public-sector jobs, while 62 per cent remained in vulnerable positions, and 23 per cent became unemployed or exited the labour force. At the same time, of the 17 per cent of formally employed male youths in 2011, 76 per cent kept their formal status in 2014.

\subsection{Cross vulnerabilities: parents' wealth and education v. job outcomes}

We next evaluate the association between household wealth or parents' education, on the one hand, and workers' current employment status, on the other. Following a growing body of literature, we use principal component analysis to impute households' wealth as an alternative indicator of workers' circumstances and vulnerability (AlAzzawi and Hlasny 2019b; Hlasny and AlAzzawi 2019).

Figures 2i-2vii report youth employment type by their families' wealth quintile. Egyptian youths from lower wealth-quintile families are shown to have been more likely to end up with vulnerable employment, particularly irregular wage and informal work (Figures 2i-iv). Formal employment was most prevalent among the wealthiest quintile. Interestingly, there were more unemployed and inactive male youths in the middle quintile in 1998 and 2006 compared to 2012, when middlewealth youths were more prone to accept informal and particularly irregular wage work. Finally, between 2012 and 2018 more of the youths in the lower-wealth quintiles were employed in informal private jobs than irregular wage work, compared to previous years.

In Jordan, formal jobs were slightly more evenly distributed across wealth quintiles in 2010 (Figures $2 \mathrm{v}$-vi). The highest-quintile group had only a minor advantage in its propensity for attaining formal public jobs, but a large advantage in attaining formal private positions. As many as one-third of youth in the second and third quintiles were employed in the public sector, in contrast to the poor employment outcomes of non-privileged Egyptian youths. Employment vulnerability also had similar prevalence across all quintiles of wealth in 2010, with the bulk of that vulnerability being in informal private employment (self-employment, unpaid family work, and irregular wage work were similarly rare across all wealth quintiles).

By 2016, employment among Jordanian youths shrank across all quintiles. The share of unemployed and economically inactive did not appear to follow any simple pattern against wealth quintiles: the outcomes were almost equally prevalent across all quintiles. Both the highest and the lowest quintiles had very similar shares of unemployed and inactive male youths. Youths in the fourth quintiles had the best employment rates in 2016 and better employment in formal positions than other quintiles.

In Tunisia (Figure 2vii), the share of young workers who were either unemployed or inactive was much higher for the lower quintiles (and compared to the 1998-2018 Egypt and 2010 Jordan cohorts). The prevalence of formal jobs was only significantly different for the top wealth quintile, which again points to a high degree of inequality of access to good jobs.

Next, we review the relationship between fathers' education and children's employment outcomes. In Egypt (Figures 3i-iv), the higher the educational attainment of the father, the smaller the prevalence of vulnerable employment and the greater the prevalence of formal employment among their offspring. This pattern had strengthened even further by 2018. It is worth noting that, in 2018, children of post-graduate fathers were more likely to stay out of the labour force, presumably unless they could find a formal sector job.

In Jordan (Figures 3v-vi), a more equal distribution of good positions is found among all youths regardless of their fathers' education. The finding of a larger share of youths being out of the labour force was the same, to a large extent, regardless of father's education. In Tunisia (Figure 
3vii), in contrast to both Egypt and Jordan, children of the least-educated fathers were the ones most likely to be unemployed or to stay out of the labour force, while children of university graduates almost exclusively worked in formal jobs, in both the public and private sectors.

\subsection{Persistence of cross vulnerabilities}

An important dimension of labour market panel surveys is their ability to track the same workers across the years. We can follow workers' employment type-and the persistence of employment vulnerability — across the years, given their initial wealth. Assessing the 2006 employment status of male workers who were young in 1998 against their family wealth in 1998 (Figure A4), we see a downward trend in the persistence of vulnerability by quintile. Youths in the lowest wealth quintile in 1998 were likely to remain vulnerable in 2006, and the likelihood of remaining vulnerable in 2006 declined with a rising wealth quintile back in 1998. The persistence of vulnerable employment further rises when we track 1998 youths to the year 2012 (Figure A4ii). Youths in the lowest quintile in 1998 were the most likely to remain vulnerably employed 14 years later, while those in higher quintiles were more likely to hold formal employment. The same trends prevailed 20 years later in 2018: individuals whose families were in the bottom wealth quintiles in 1998 were the most likely to be vulnerably employed in 2018 and the least likely to have a formal job whether public or private.

Workers who were youths in 2006 experienced greater inequalities. More than 60 per cent of 2006 youths in the lowest quintile in 2006 were vulnerably employed by 2012 (Figure A4iii), while only a third of those from the highest quintile remained vulnerably employed that year. An even more pronounced trend along the same direction persisted for those 2006 youths all the way to 2018 (Figure A4v). For those who were youths in 2012, there is once again a clear negative relation: the higher the wealth quintile in 2012 the higher the prospect of landing formal employment and the lower the prospect of vulnerability in 2018 (Figure A4vi). Over 70 per cent of 2012 youths whose families were in the bottom quintile ended up in vulnerable jobs in 2018.

For Jordan, we examine how family wealth affected the 2010 youths in their propensity for employment vulnerability in 2016 (Figure A4vii). Despite the lower prevalence of vulnerable employment in Jordan compared to Egypt, higher wealth was still linked to a lower probability of vulnerable employment in 2016. Unemployment and economic inactivity were the most prominent year-2016 outcomes among Jordanian youths. Nevertheless, higher wealth in 2010 was still associated with a slightly lower risk of unemployment and inactivity. Formal employment in 2016 was also most prevalent among 2010 youths from the highest-quintile families in 2010. Lastly, while we cannot cross-examine the employment outcomes of Tunisian workers in 2014 and their household wealth in prior years, a similar analysis of household wealth in 2014 is reported in Figure 2vii.

Next, we examine workers' employment status by father's education (Figures A5i-vii in the Appendix). In Egypt, having a father with less than intermediate education is strongly associated with vulnerable employment in the subsequent six to eight years, and even 20 years later for 1998 and 2006 youths. By contrast, having a highly educated father is associated with having a formal job even two decades later. The relationship became stronger over time such that 2012 youths with a father with less than intermediate education were almost four times more likely to end up in a vulnerable job than in a formal job. For the Jordan 2016 youths (Figure A5vii), the association is generally not as high as in Egypt. In Tunisia, again, we cannot take advantage of the panel dimension, but we report the association between workers' employment status and their fathers' education (as reported in the same survey wave) in Figure 3vii. 


\subsection{Earnings vulnerability}

For another dimension of vulnerability, we assess the labour income vulnerability of Egyptian and Jordanian youths. We use current labour market earnings for regular wage workers to evaluate the prevalence of low labour earnings and earnings mobility. This analysis cannot be performed for Tunisia as only one point in time is available.

For Egypt and Jordan, we use two benchmarks to identify low earnings: a relative one based on belonging to the lowest earnings quintile, and an absolute one based on comparing labour earnings to a government-set low earnings line (LEL). The LELs are taken from official poverty lines (PL) obtained from CAPMAS (2018), Jordanian DOS (2010), and World Bank (2016). To compute an individual-level monthly LEL, the annual PL/capita is divided by 12 and multiplied by the household-level dependency ratio as each worker typically supports more than one family member.

Table 1 shows vulnerability in labour earnings according to both the relative and absolute benchmarks, distinguishing young and older workers. According to the LELs, across all years in Egypt, youths are 1.5 to 2.5 times more likely than non-youths to have labour earnings among the lowest quintile or to be low earners.

In Jordan in 2010, youths were also twice as likely to be in the lowest quintile or low earners relative to the LEL. By 2016 this had changed, however, and there was no significant difference between youths and non-youths. For both categories, there was a one in four chance of being in the bottom quintile and about 3 per cent were earning below the LEL. In Tunisia, youths were also at a significant relative disadvantage compared to non-youths, with 1.5 times as many in the bottom quintile as non-youths. For both categories, about 4 per cent were earning below the LEL.

\subsection{The effects of workers' circumstances on employment outcomes}

To investigate the standalone role of workers' various circumstances, we estimate multinomial logistic regressions of workers' employment status on the conditions in their youth, 6-20 years prior (Assaad et al. 2014; Assaad and Krafft 2014). The contribution of this study is to analyse the detailed occupational distribution among youths and non-youths separately using longitudinal data in pooled surveys. We thus derive the changes in labour market prospects for youths and nonyouths over time, mitigate the potential endogeneity of workers' circumstances by using their backgrounds from previous survey waves, and mitigate heteroskedasticity in the estimations due to latent heterogeneity across workers.

Multinomial logit regressions are used to fit the probability that an individual will attain a specific value of a dependent variable-here employment status-compared to the probability of a baseline value-remaining economically inactive. This baseline was selected as a natural state among fresh graduates contemplating whether to begin job hunting and can be thought of as the least-preferred state, which is helpful for interpreting regression parameters. The model takes the values of regressors, estimates outcome-specific parameters on those regressors using maximum likelihood, and computes the probabilities of all the alternative outcomes. The outcome with the greatest probability of occurring is set as the estimated outcome.

Tables $2-4$ report the main regression specifications estimated on pooled surveys for each country, separately for youth and non-youth workers. (Table A1 reports the regressions for the combined sample of youth and non-youth workers.) The parameters in Tables 2-4 exponentiated and lowered by 1 -are the estimated changes in the probability of each outcome relative to the probability of remaining inactive resulting from a unit jump in the corresponding regressor. Positive parameters indicate a rise in the probability of an outcome relative to the baseline, and 
negative parameters indicate a fall. In what follows, we omit mentioning that the probabilities are relative to the baseline option.

Table 2 shows the estimates for the pooled 2006-18 ELMPSs, where workers' employment outcomes in 2006-18 are linked to their circumstances in 1998, 2006, or 2012. As expected, workers' employment prospects are associated positively with their age, albeit with a slowly diminishing rate. Female workers have significantly lower employment prospects than men in all types of jobs, and even have a lower probability of being unemployed relative to their high risk of being out of the labour force.

Being literate and having a higher educational attainment increases the prospect of attaining formal employment in the public or private sector but has a surprisingly modest effect on other types of employment. Above-intermediate education has the strongest effect across most employment types. Formal employment is the only occupation status where higher education offers systematically positive and significant (marginal) returns among youth as well as non-youth workers, so that secondary and tertiary school graduates have the highest odds of being employed there. Interestingly, the secondary- and tertiary-educated workers also have a high risk of being unemployed, suggesting that these workers may be rejecting inferior opportunities in search of formal employment. Among female workers, education typically offers higher returns in terms of their prospects of being economically active than among men, because most education-gender interaction terms-except for the model of unpaid family work but including the model of unemployment - are positive. The effect is strongest for the prospects of formal employment and unemployment and at the above-intermediate and tertiary education level. As, for men, this suggests that higher-educated women join the labour force but shun inferior job opportunities in search of formal employment.

Several results stand out related to workers' family backgrounds. Household wealth has a negative effect on workers' employment prospects, except for the prospect of becoming an employer, where it has no effect. Interestingly, the wealth effect is as high among non-youth workers as among youths. Family wealth thus has lifelong implications for workers' employment. Fathers' education and employment status, by contrast, play a greater role in the employment prospects of youth workers. Fathers' higher education is associated with a lower probability of informal employment and self-employment among their offspring, especially among youths. Fathers' employment status has a strong effect on children's employment prospects, with the interesting finding that fathers who are employers are more likely to have children who are self-employed or unpaid family workers, or who become employers themselves. These children are significantly less likely to hold formal or informal paid work, or to be searching for work.

There are clear regional disparities in employment prospects, with workers from urban lower and urban upper governorates having better prospects, especially among non-youth workers. Workers from rural areas are more likely to become self-employed or unpaid family workers, or to serve as employers, but these results are insignificant when country regions are controlled for. Finally, there is strong evidence that employment prospects for formal employment, self-employment, and becoming employers deteriorated between 2006 and 2012. As the odds of becoming informal/irregular workers significantly increased, some youth workers gave up on their job search and remained out of the labour force, while non-youth workers joined the ranks of the unemployed.

Table 3 reports the same regressions as those estimated on the 2010-16 surveys for Jordan. The workers' employment outcomes are taken from the 2016 wave, while their circumstances and youth status are taken from the 2010 wave. As in Egypt, workers' employment prospects are strongly and positively associated with their age, particularly their likelihood of becoming 
employers of others. This effect of age diminishes only very slowly. Women are again substantially less likely to hold any type of employment, but the male-female gaps in the employment likelihoods are much lower in Jordan than in Egypt.

Education confers a systematically positive benefit in terms of the likelihood of decent employment, which is very significant for formal employment and for the prospect of becoming an employer. In contrast to Egypt, in Jordan we find that even primary and secondary education has a clear positive impact on youth workers' odds of labour market participation. Higher education levels are associated only with a higher likelihood of formal employment. Those with less than intermediate education have a comparable likelihood of labour market participation as college graduates. The benefit of advanced education comes from a significantly improved prospect of formal employment. Among women, university education appears to have a stronger effect on their employment prospects, particularly on formal employment and on the likelihood of searching for work. Some parameters on the gender-education interaction terms and on household-head gender are large, suggesting that collinearity among covariates or a few influential observations, particularly when pursued by many explanatory variables, may be causing problems. This occurs particularly in models of the prospects of becoming an employer or self-employed, where the sample of women is relatively small. The absolute sizes of the relevant parameters must therefore be viewed with caution.

Among household circumstances, household wealth has a negative effect on workers' employment prospects, except for becoming an employer, where it has a strong positive effect. The wealth effect on the odds of attaining formal or informal employment, or of searching for jobs, is negative in Jordan. Like in Egypt, the wealth effect appears to be as strong or even stronger among nonyouth workers, suggesting that initial family wealth is relevant throughout workers' careers. Fathers' education, on the other hand, has a weak effect on employment prospects, without any consistent patterns. Fathers' employment type also has a weak effect on the likelihood of their offspring's employment status, even though there is some evidence of intergenerational transmission of employment status. Fathers' employment type has the greatest impact on the likelihood of similar employment types among their offspring. Children of economically inactive fathers have weak odds of working or searching for jobs. Fathers who are self-employed or employers are particularly likely to have children who are self-employed/unpaid or employers, and less likely to have children working in the formal sector or being unemployed.

Like in Egypt, we find a great regional disparity in employment prospects between the Central region (baseline) and the North and South regions, and between urban and rural areas. Workers in the North and South regions have significantly higher odds of landing formal jobs, and of searching for work, and have lower odds of being self-employed or having an informal job. In rural areas, workers are substantially less likely to be self-employed or an employer, have an informal job, or be searching for a job. Urban workers appear to have higher odds of being unemployed. The availability of decent jobs relative to the pool of applicants aspiring to get them is lower in urban areas. This may be the effect of an influx of refugees on the availability of informal and other unskilled jobs.

Lastly, Table 4 reports on the same regressions as those estimated on the 2014 survey for Tunisia. Because only one survey wave is available, all covariates are taken from the same year, with the exception of youth status (taken from six years prior, i.e. 2008), residence (urban/rural and region of birthplace), and fathers' characteristics when the worker was aged 15 . We again find a strong positive but diminishing effect of age on employment (as well as unemployment) prospects, and a strong negative effect of being female. Workers' higher education is strongly and positively associated with formal employment. Interestingly, among youth workers, higher education is associated negatively with becoming self-employed or an employer, and positively with 
unemployment, while among non-youth workers the opposite is the case. Among youths, women's return to education in terms of the odds of formal employment is lower than among men, while it is higher among older workers. On the other hand, higher-educated young women are less likely to remain unemployed than their male counterparts, while the opposite is true among highereducated older women.

Household wealth increases the prospect of becoming an employer and lowers the risk of irregular employment and unemployment. Like in Egypt and Jordan, the wealth effect is highly persistent across youth and non-youth ages. Fathers' education is negatively correlated with the risk of unemployment, but little can be said about its effect on other employment statuses because the parameters appear to be implausibly high. Data problems, including a small sample of highly educated fathers or incidental collinearity with other covariates, are likely at play. Like in Egypt and Jordan, fathers' self-employment or status as an employer has a strong positive effect on their offspring's own self-employment or employer status. Finally, workers from rural areas are more likely to be self-employed or unpaid family workers, and less likely to remain unemployed.

Figure 4 (and Figures A6-A8) plots the smoothed probabilities of all employment statuses by age, level of education, or wealth index score. This figure shows that in Egypt the prospect of informal employment falls with workers' ages, and the prospect of formal employment continuously rises. In Jordan and Tunisia, by contrast, the likelihood of formal employment peaks around age 40 and falls thereafter, and that of informal employment stagnates throughout workers' lives.

In addition to the baseline models in Tables 2-4, estimations were conducted as robustness checks of the sample composition and of the dynamics in workers' employment trends. To address the question of job transition from vulnerable employment, we restricted the samples in Tables 2-4 to those who were vulnerable in the prior period (previous survey wave in Egypt and Jordan, first previous employment status in Tunisia). The results show that the risk factors for transition out of vulnerability to various employment sectors are somewhat different to those for the general population of workers (regression results available on request; predicted lines shown in Figure 5). Parameter sizes change systematically from their levels in Tables 2-4 because of the sample restriction but are generally less significant because of the smaller sample sizes. We find that higher education is more strongly associated with upward mobility, while higher household wealth, rural residence, and having a female household head are all associated negatively with upward mobility. These parameters are not too far apart from those in Tables $2-4$, because the restriction does not affect a large share of male workers who started their youth lives in informal, irregular, or selfemployment. Those starting in formal jobs or as employers can be seen as outliers who do not affect the predicted parameters too much.

Comparing Figures 4 and 5, the two critical differences are that among vulnerably employed men the odds of formal employment are significantly lower than in the general sample of all men, and the odds of informal/irregular employment are significantly higher. Among all men, we have seen that the odds of formal employment rise sharply with age, and begin to dominate all other employment statuses by the ages of 28-39 in Egypt and by the ages of 22-26 in Jordan and Tunisia. By contrast, among men initially employed in vulnerable occupations, the odds of formal employment are much flatter and never dominate the odds of informal employment. In Egypt, they are half as high or lower than the odds of informal employment across all ages. In Tunisia, they are half as high until the age of 42 , and then gradually approach the odds of informal employment by the age of 56. In Jordan, the odds of formal employment are nearly as high as the 
odds of informal employment until the age of 36 and fall to two-thirds of the odds of informality for higher-age workers. ${ }^{8}$

\section{$5 \quad$ Conclusions and policy implications}

We studied youth vulnerabilities in Egypt, Jordan, and Tunisia in terms of employment statuses and the set of protections afforded to workers. We relied on panel data to analyse the outcomes of youths in 1998, 2006, 2012, and all the way to 2018 in Egypt. For Jordan, we tracked individuals between 2010 and 2016. We only had data for 2014 for Tunisia but were still able to examine vulnerability statically and over a span of three years, as well as cross vulnerabilities using workers' birthplace, father's education and employment, and household wealth.

We found that youths in all three countries were disadvantaged in terms of their employment status, with most youths landing vulnerable positions including self-employment, unpaid family work, irregular wage work, or informal private-sector work. Youth employment is likely to be associated with lower pay and this likelihood increases across the years, particularly in Egypt. In Jordan in 2016, a notable change was that larger groups of youths were either unemployed or out of the labour force rather than in vulnerable jobs. This was not the case in 2010 and could be a reflection of changing market conditions as a result of the regional crisis and a resulting surge in migrant workers.

Dynamic analysis confirms that youths who started out in vulnerable positions had a hard time transitioning to decent jobs later. Some even moved 'down' to informal jobs, particularly those who were employers in 2012 and 2006. Parents' wealth and education affected workers' lifetime employment statuses. Lower wealth and having less-educated fathers were very strong determinants of vulnerable employment. There was a clear and stark reduction in this negative association at higher levels of wealth and for more-educated fathers. More importantly, these associations between family circumstances and employment outcomes persisted even years later20 years in the case of Egypt. Similar patterns persisted for Jordan and Tunisia in terms of family wealth. Fathers' education had a different impact in Tunisia, with children of the least-educated fathers more likely to be unemployed or to remain inactive, while children of university graduates were almost exclusively in formal jobs.

Multinomial logit regressions confirm that youth workers were less likely to obtain good jobs than older workers. Comparing the regression results for Egypt, Jordan, and Tunisia, we found many consistencies in the demographic distribution across different types of jobs. College graduates in all three countries had a high probability of remaining unemployed, perhaps hoping to land formal private or public employment. While workers could rely on consistent returns to education through prospects for better employment, substantial differences in the returns existed between males and females, and females remained most likely to be out of the labour force. Family wealth helped to explain workers' career-long job mobility, while parental education and employment mattered mostly in workers' youth.

These results suggest that even among wage jobs, work may be informal, low-security, and lowpay. It is crucial not to limit attention to unemployment and self-employment rates as youth

\footnotetext{
8 The models for Egypt were estimated with random effects, and even with fixed effects, to limit the effects of unobserved heterogeneity across workers. As an alternative to the models restricted to initially vulnerably employed workers (Figure 5), dynamic models were considered using prior labour market experience as a factor influencing current job. These models suffer from potential endogeneity of the prior labour market experience.
} 
employment indicators. If the objective of youth programmes is to secure decent work for young people, then productivity, compensation, social protection, occupational safety, health, and job security need to be reviewed.

Our results inform policy makers about the vital support systems needed for vulnerable workers, especially youths, the poor, and those with less-educated parents. They provide insights into the challenges young people face and the inefficiencies in matching formal jobs with talent, as family wealth and socio-economic background still dominate individual skills and effort. We hope these results can be used to create a better framework for aligning skill supply with demand and to create more acceptable working conditions in the informal and formal sectors to facilitate worker mobility and greater economic efficiency.

\section{References}

Agénor, P.-R., H.T. Jensen, M. Nabli, and T. Yousef (2004). 'Labor Market Reforms, Growth, and Unemployment in Labor-exporting Countries in the Middle East and North Africa'. Social Protection Working Paper 3328. Washington, DC: World Bank. https://doi.org/10.1596/1813-9450-3328

AlAzzawi, S., and V. Hlasny (2018). 'Youth Vulnerability in Egypt and Jordan'. ERF Working Paper 1275. Cairo: Economic Research Forum.

AlAzzawi, S., and V. Hlasny (2019a). 'Disparities in the Cost of Living Changes After a Large-scale Devaluation: The Case of Egypt 2016'. Topics in Middle Eastern and African Economies, 21(2): 1-32.

AlAzzawi, S., and V. Hlasny (2019b). 'Household Asset Wealth and Female Labor Supply in MENA'. Quarterly Review of Economics and Finance, 73: 3-13. https://doi.org/10.1016/j.qref.2019.08.002

Amer, M. (2012). 'The School-to-Work Transition of Jordanian Youth'. ERF Working Paper 686. Cairo: Economic Research Forum.

Amer, M. (2015). 'Patterns of Labor Market Insertion in Egypt, 1998-2012'. In R. Assaad and C. Krafft (eds), The Egyptian Labor Market in an Era of Revolution. Oxford: Oxford University Press. https://doi.org/10.1093/acprof:oso/9780198737254.003.0004

Assaad, R. (2012). 'The Structure and Evolution of Employment in Jordan'. ERF Working Paper 674. Cairo: Economic Research Forum.

Assaad, R. (2014). 'Making Sense of Arab Labor Markets: The Enduring Legacy of Dualism'. IZA Journal of Labor and Development, 3(1): 1-25. https:/ / doi.org/10.1186/2193-9020-3-6

Assaad, R., C. Binzel, and M. Gadallah (2010). 'Transitions to Employment and Marriage Among Young Men in Egypt'. Middle East Development Journal, 2(1): 39-88. https://doi.org/10.1142/S1793812010000162

Assaad, R., R. Hendy, and S. Yassin (2014). 'Gender and the Jordanian Labor Market'. In R. Assaad (ed.), The Jordanian Labour Market in the New Millennium. Oxford: Oxford University Press. https://doi.org/10.1093/acprof:oso/9780198702054.001.0001

Assaad, R., and C. Krafft (2014). 'Youth Transitions in Egypt: School, Work, and Family Formation in an Era of Changing Opportunities'. Silatech Working Paper 14-1. Doha: Silatech.

Assaad, R., and C. Krafft (2015). 'The Structure and Evolution of Employment in Egypt: 1998-2012'. In R. Assaad and C. Krafft (eds.), The Egyptian Labor Market in an Era of Revolution. Oxford: Oxford University Press. https://doi.org/10.1093/acprof:oso/9780198737254.001.0001

Assaad, R., C. Krafft, and D. Salehi-Isfahani (2018). 'Does the Type of Higher Education Affect Labor Market Outcomes? Evidence from Egypt and Jordan'. Higher Education, 75(6): 945-95.

https://doi.org/10.1007/s10734-017-0179-0 
Assaad, R., C. Krafft, and C. Salemi (2019). 'Socioeconomic Status and the Changing Nature of the Schoolto-Work Transition in Egypt, Jordan, and Tunisia', ERF Working Paper 1287. Cairo: Economic Research Forum.

Barsoum, G., and D. Abdalla (2020). 'Still the Employer of Choice: Evolution of Public Sector Employment in Egypt'. ERF Working Paper 1386. Cairo: Economic Research Forum.

Binzel, C. (2011). 'Decline in Social Mobility: Unfulfilled Aspirations Among Egypt's Educated Youth'. IZA Discussion Paper 6139. Bonn: IZA.

CAPMAS (Central Agency for Public Mobilization and Statistics) (2018). Egypt in Figures. Cairo: CAPMAS.

Danquah, M., S. Schotte, and K. Sen (2019). 'Informal Work in Sub-Saharan Africa: Dead End or Stepping Stones?'. WIDER Working Paper 2019/107. Helsinki: UNU-WIDER. https://doi.org/10.35188/UNU-WIDER/2019/743-9

DOS (Jordanian Department of Statistics) (2010). Poverty Status in Jordan. Amman: DOS.

Egel, D., and D. Salehi-Isfahani (2010). 'Youth Transitions to Employment and Marriage in Iran: Evidence from the School to Work Transition Survey'. Middle East Development Journal, 2(1): 89-120. https://doi.org/10.1142/S1793812010000198

Ehab, M. (2019). 'Employment Transitions of Youth and Health Implications in Egypt'. ERF Working Paper 1355. Cairo: Economic Research Forum.

El-Haddad, A. (2020). 'Redefining the Social Contract in the Wake of the Arab Spring: The Experiences of Egypt, Morocco and Tunisia'. World Development, 127(104774). https://doi.org/10.1016/j.worlddev.2019.104774

El-Mekkaoui, N., and Z. Chaker (2020). 'Informal Labor and the Expansion of Social Security Programs: Evidence from Jordan and Tunisia'. ERF Annual Conference paper 235. Cairo: Economic Research Forum.

Fehling M., Z.M. Jarrah, M.E. Tiernan, S. Albezreh, M.J. VanRooyen, A. Alhokair, and B.D. Nelson (2016). Youth in Crisis in the Middle East and North Africa: A Systematic Literature Review and Focused Landscape Analysis'. Eastern Mediterranean Health Journal, 21(12): 916-30. https://doi.org/10.26719/2015.21.12.916

Hlasny, V., and S. AlAzzawi (2018). 'Return Migration and Socioeconomic Mobility in MENA: Evidence from Labor Market Panel Surveys’. WIDER Working Paper 2018/35. Helsinki: UNU-WIDER. https://doi.org/10.35188/UNU-WIDER/2018/477-3

Hlasny, V., and S. AlAzzawi (2019). 'Asset Inequality in MENA: The Missing Dimension?'. Quarterly Review of Economic and Finance, 73: 44-55. https:// doi.org/10.1016/j.qref.2018.07.010

ILO (International Labour Organization) (2020a). 'Global Employment Trends for Youth 2020: Africa'. Available at: https://www.ilo.org/wcmsp5/groups/public/---dgreports/--dcomm/documents/briefingnote/wcms_737670.pdf (accessed 25 November 2020).

ILO (International Labour Organization) (2020b). 'Global Employment Trends for Youth 2020: Arab States'. Available at: https://www.ilo.org/wcmsp5/groups/public/---dgreports/--dcomm/documents/briefingnote/wcms_737672.pdf (accessed 25 November 2020).

Kabbani, N., and E. Kothari (2005). 'Youth Employment in the MENA Region: A Situational Assessment'. Social Protection Discussion Paper 534. Washington, DC: World Bank.

Krafft, C., and R. Assaad (2016). 'Inequality of Opportunity in the Labor Market for Higher Education Graduates in Egypt and Jordan'. In I. Diwan and A. Galal (eds), The Middle East Economies in Times of Transition. International Economic Association Series. London: Palgrave Macmillan. https://doi.org/10.1007/978-1-137-52977-0_6

Majbouri, M. (2017). 'Income Mobility and the Arab Spring: The Case of Egypt and Jordan'. Applied Economics Letters, 24(15): 1070-74. https://doi.org/10.1080/13504851.2016.1254332 
Mryyan, N. (2012). 'Demographics, Labor Force Participation and Unemployment in Jordan'. ERF Working Paper 670. Cairo: Economic Research Forum.

OAMDI (Open Access Micro Data Initiative) (2019). 'Labor Market Panel Surveys (LMPS), Version 2.0 of Licensed Data Files; ELMPS 1998, 2006, 2012, 2018 panel v.2.0; JLMPS 2010, 2016 panel v.1.1; TLMPS 2014 v.2.0. Cairo: Economic Research Forum. Available at: https://erf.org.eg/oamdi/ (accessed 27 November 2020).

Pieters, J. (2013). 'Youth Employment in Developing Countries'. Background Paper DCIEDUC/2012/310-255. Luxembourg: European Commission.

Shahen, M.E., K. Kotani, M. Kakinaka, and S. Managi (2020). 'Wage and Labor Mobility Between Public, Formal Private and Informal Private Sectors in a Developing Country'. Economic Analysis and Policy, 68: 101-13. https:// doi.org/10.1016/j.eap.2020.09.006

Stampini, M., and A. Verdier-Chouchane (2011) 'Labor Market Dynamics in Tunisia: The Issue of Youth Unemployment'. IZA Discussion Paper 5611. Bonn: IZA.

WEF (World Economic Forum) (2012). Addressing the 100 Million Youth Challenge: Perspectives on Youth Employment in the Arab World in 2012. Geneva: World Economic Forum.

Woolard, I., and S. Klasen (2005). 'Determinants of Income Mobility and Household Poverty Dynamics in South Africa'. Journal of Development Studies, 41(5): 865-97.

World Bank (2016). ‘Tunisia Poverty Assessment 2015’. World Bank Other Operational Studies 24410, Washington, DC: World Bank.

World Bank (2020). 'Metadata Glossary: Vulnerable Employment, World Bank Databank'. Available at: https://databank.worldbank.org/metadataglossary/world-developmentindicators/series/SL.EMP.VULN.ZS (accessed 27 November 2020). 


\section{Tables and figures}

Table 1a: Mean monthly earnings by employment status, in local currency

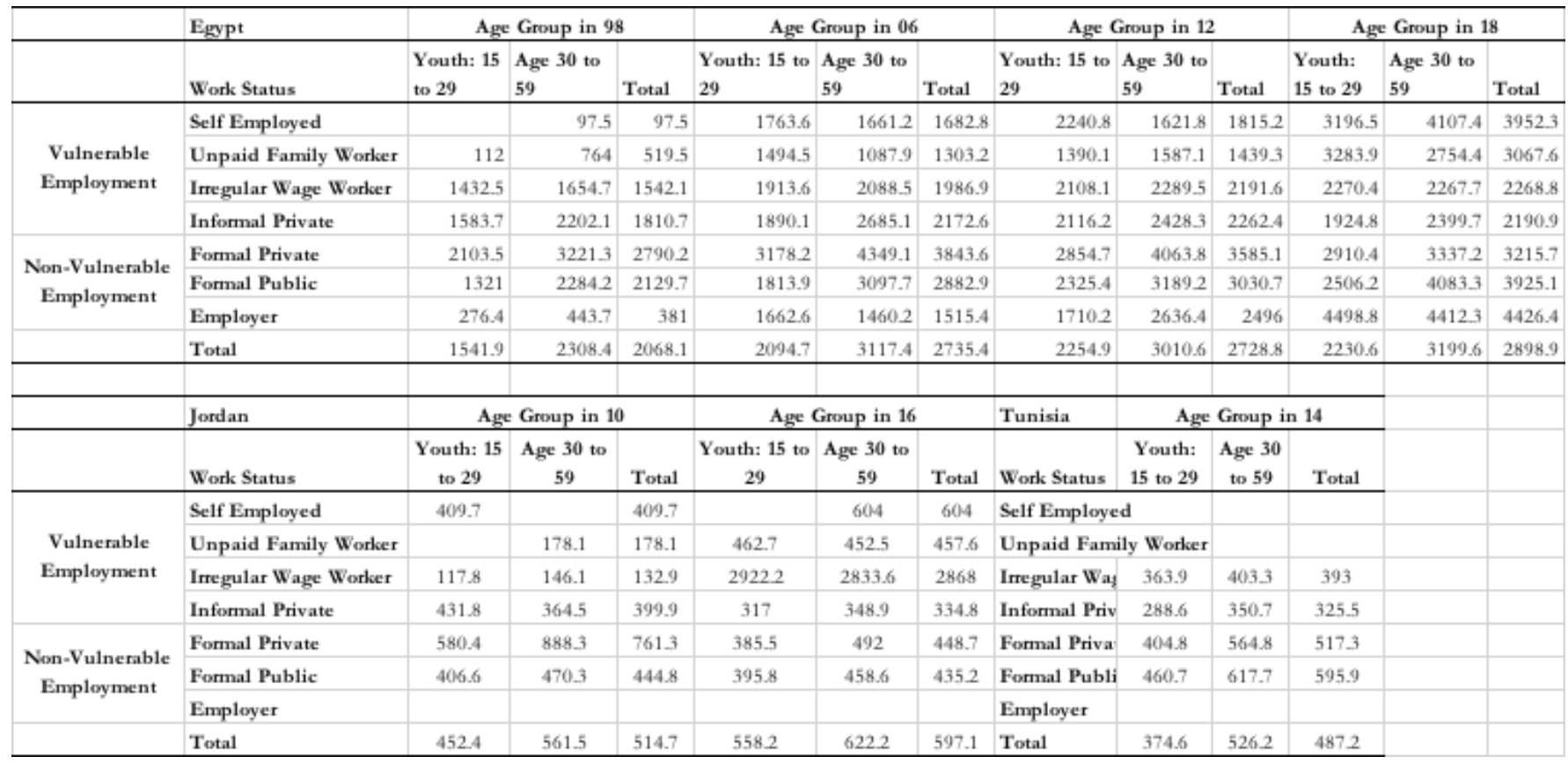

Note: monthly earnings are in 2018 EGP for Egypt for all years and in 2017 JDs for Jordan for all years.

Source: authors' calculations based on ELMPS 1998-2018, JLMPS 2010-16, TLMPS 2014 (OAMDI 2019).

Table 1b: Relative and absolute earnings vulnerability (\%)

Non-student youths: Non-youths: 15-29 30-59

All

Relative earnings vulnerability:

Country
Relative earnings vulnert
Lowest quintile

\begin{tabular}{lllll}
\hline EGYPT & 1998 Earnings & 29.73 & 13.61 & 19.23 \\
& 2006 Earnings & 34.87 & 13.13 & 21.28 \\
& 2012 Earnings & 26.70 & 16.30 & 19.89 \\
& 2018 Earnings & 28.22 & 16.87 & 20.15 \\
JORDAN & 2010 Earnings & 29.01 & 15.69 & 21.35 \\
& 2016 Earnings & 26.55 & 25.49 & 25.85 \\
TUNISIA & 2014 Earnings & 28.90 & 17.29 & 20.41
\end{tabular}

\begin{tabular}{llccc}
\hline \multicolumn{5}{c}{$\begin{array}{c}\text { Absolute earnings vulnerability: } \\
\text { Low earners compared to LEL }\end{array}$} \\
\hline EGYPT & 1998 Earnings & 18.11 & 6.90 & 10.71 \\
& 2006 Earnings & 14.38 & 5.33 & 8.69 \\
& 2012 Earnings & 9.30 & 5.72 & 6.93 \\
& 2018 Earnings & 10.14 & 8.11 & 8.65 \\
JORDAN & 2010 Earnings & 4.02 & 1.35 & 2.49 \\
TUNISIA & 2016 Earnings & 2.36 & 2.91 & 2.73 \\
& 2014 Earnings & 4.82 & 3.90 & 4.15
\end{tabular}

Source: authors' calculations based on ELMPS 1998-2018, JLMPS 2010-16, TLMPS 2014 (OAMDI 2019). 
Table 2: Multinomial logit regressions on pooled ELMPS 2006-18 data, youth v. non-youth

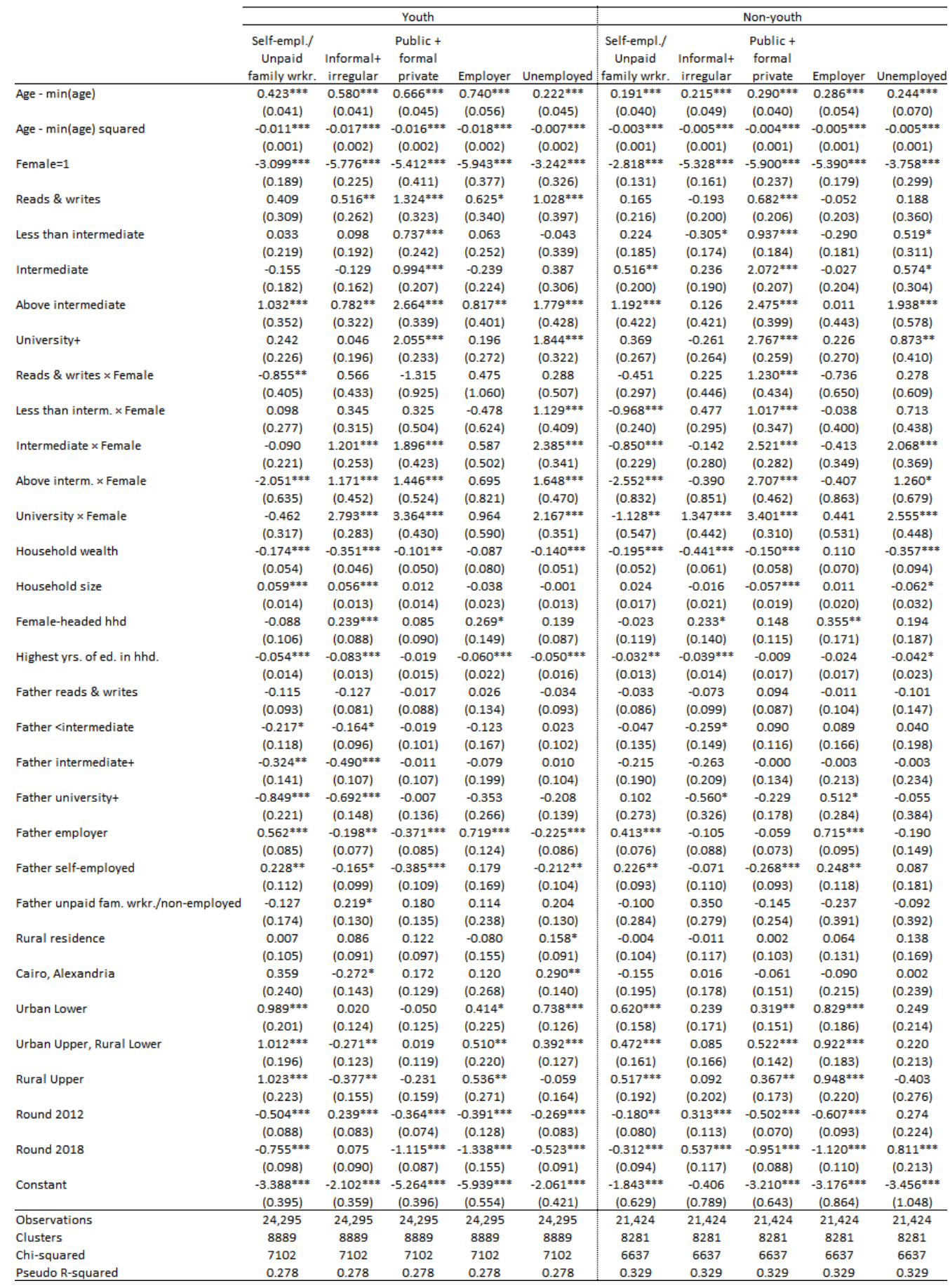

Note: samples weighted using individual-level weights. Standard errors clustered at household level are in parentheses, ${ }^{\star \star \star} p<0.01,{ }^{\star \star} p<0.05,{ }^{*} p<0.1$. Workers' status as 'youth' and all household-level variables are lagged by one survey wave to estimate the effect of workers' circumstances in their youth on their subsequent outcomes.

Source: authors' calculations based on ELMPS 1998-2018 (OAMDI 2019). 
Table 3: Multinomial logit regressions on JLMPS16, separating youth and non-youth

\begin{tabular}{|c|c|c|c|c|c|c|c|c|c|c|}
\hline & \multicolumn{5}{|c|}{ Youth } & \multicolumn{5}{|c|}{ Non-youth } \\
\hline & $\begin{array}{l}\text { Self-empl./ } \\
\text { Unpaid } \\
\text { family wrkr. }\end{array}$ & $\begin{array}{c}\text { Informalt+ } \\
\text { irregular }\end{array}$ & $\begin{array}{l}\text { Public + } \\
\text { formal } \\
\text { private }\end{array}$ & Employer & Unemployed & $\begin{array}{l}\text { Self-empl./ } \\
\text { Unpaid } \\
\text { family wrkr. }\end{array}$ & $\begin{array}{c}\text { Informal+ } \\
\text { irregular }\end{array}$ & $\begin{array}{l}\text { Public + } \\
\text { formal } \\
\text { private }\end{array}$ & Employer & Unemployed \\
\hline Age - min(age) & $\begin{array}{l}0.999^{* *} \\
(0.416)\end{array}$ & $\begin{array}{c}0.550^{* * *} \\
(0.148)\end{array}$ & $\begin{array}{c}0.887^{* * *} \\
(0.267)\end{array}$ & $\begin{array}{c}0.919^{* * *} \\
(0.301)\end{array}$ & $\begin{array}{c}1.109^{* * *} \\
(0.236)\end{array}$ & $\begin{array}{c}0.699^{* * *} \\
(0.247)\end{array}$ & $\begin{array}{l}0.446^{* *} \\
(0.209)\end{array}$ & $\begin{array}{c}0.641^{* * *} \\
(0.136)\end{array}$ & $\begin{array}{c}0.997^{* * * *} \\
(0.361)\end{array}$ & $\begin{array}{c}0.210 \\
(0.132)\end{array}$ \\
\hline Age - min(age) squared & $\begin{array}{l}-0.014^{*} \\
(0.007)\end{array}$ & $\begin{array}{c}-0.007^{* * *} \\
(0.002)\end{array}$ & $\begin{array}{c}-0.013^{* * *} \\
(0.005)\end{array}$ & $\begin{array}{c}-0.011^{* *} \\
(0.005)\end{array}$ & $\begin{array}{c}-0.020^{* * *} \\
(0.004)\end{array}$ & $\begin{array}{c}-0.008^{* * *} \\
(0.003)\end{array}$ & $\begin{array}{c}-0.005^{* *} \\
(0.002)\end{array}$ & $\begin{array}{c}-0.008^{* * *} \\
(0.001)\end{array}$ & $\begin{array}{c}-0.011^{* * * *} \\
(0.004)\end{array}$ & $\begin{array}{c}-0.003^{* *} \\
(0.002)\end{array}$ \\
\hline Female $=1$ & $\begin{array}{c}-4.711^{* * * *} \\
(0.504)\end{array}$ & $\begin{array}{c}-3.876^{* * *} \\
(0.319)\end{array}$ & $\begin{array}{c}-4.270^{* * * *} \\
(0.211)\end{array}$ & $\begin{array}{c}-6.412^{* * *} \\
(1.060)\end{array}$ & $\begin{array}{c}-1.920^{* * *} \\
(0.199)\end{array}$ & $\begin{array}{c}-4.616^{* * *} \\
(0.388)\end{array}$ & $\begin{array}{c}-3.606^{* * *} \\
(0.346)\end{array}$ & $\begin{array}{c}-3.271^{* * *} \\
(0.172)\end{array}$ & $\begin{array}{c}-5.650^{* * * *} \\
(0.737)\end{array}$ & $\begin{array}{c}-2.351^{* * *} \\
(0.236)\end{array}$ \\
\hline Reads \& writes & $\begin{array}{l}1.420^{* *} \\
(0.642)\end{array}$ & $\begin{array}{c}0.498 \\
(0.499)\end{array}$ & $\begin{array}{c}1.352^{* * *} \\
(0.474)\end{array}$ & $\begin{array}{c}1.629 \\
(1.097)\end{array}$ & $\begin{array}{l}-0.041 \\
(0.432)\end{array}$ & $\begin{array}{c}0.210 \\
(0.504)\end{array}$ & $\begin{array}{l}-0.689 \\
(0.552)\end{array}$ & $\begin{array}{c}0.361 \\
(0.412)\end{array}$ & $\begin{array}{l}-0.282 \\
(0.755)\end{array}$ & $\begin{array}{l}-0.967^{*} \\
(0.510)\end{array}$ \\
\hline Less than intermediate & $\begin{array}{l}1.298^{* *} \\
(0.646)\end{array}$ & $\begin{array}{c}0.790 \\
(0.497)\end{array}$ & $\begin{array}{c}2.144^{* * *} \\
(0.446)\end{array}$ & $\begin{array}{c}0.790 \\
(1.112)\end{array}$ & $\begin{array}{c}0.200 \\
(0.398)\end{array}$ & $\begin{array}{l}-0.158 \\
(0.529)\end{array}$ & $\begin{array}{l}-0.099 \\
(0.539)\end{array}$ & $\begin{array}{l}0.738^{*} \\
(0.404)\end{array}$ & $\begin{array}{l}-0.710 \\
(0.776)\end{array}$ & $\begin{array}{l}-0.845^{*} \\
(0.491)\end{array}$ \\
\hline Secondary edu. & $\begin{array}{c}0.485 \\
(0.749)\end{array}$ & $\begin{array}{c}0.785 \\
(0.532)\end{array}$ & $\begin{array}{c}2.177^{* * *} \\
(0.461)\end{array}$ & $\begin{array}{c}0.819 \\
(1.150)\end{array}$ & $\begin{array}{c}0.373 \\
(0.407)\end{array}$ & $\begin{array}{l}-0.029 \\
(0.563)\end{array}$ & $\begin{array}{l}-0.795 \\
(0.604)\end{array}$ & $\begin{array}{c}1.386^{* * *} \\
(0.416)\end{array}$ & $\begin{array}{l}-0.737 \\
(0.797)\end{array}$ & $\begin{array}{l}-0.589 \\
(0.519)\end{array}$ \\
\hline University+ & $\begin{array}{c}0.229 \\
(0.760)\end{array}$ & $\begin{array}{l}-0.437 \\
(0.629)\end{array}$ & $\begin{array}{c}1.944^{* * *} \\
(0.515)\end{array}$ & $\begin{array}{l}-1.223 \\
(1.311)\end{array}$ & $\begin{array}{c}0.319 \\
(0.468)\end{array}$ & $\begin{array}{c}0.537 \\
(0.731)\end{array}$ & $\begin{array}{l}-1.088 \\
(0.783)\end{array}$ & $\begin{array}{c}2.410^{* * *} \\
(0.498)\end{array}$ & $\begin{array}{l}-0.836 \\
(0.935)\end{array}$ & $\begin{array}{l}-0.430 \\
(0.734)\end{array}$ \\
\hline University $\times$ Female & $\begin{array}{l}2.172^{* *} \\
(1.030)\end{array}$ & $\begin{array}{c}2.183^{* * *} \\
(0.603)\end{array}$ & $\begin{array}{c}3.112^{* * *} \\
(0.313)\end{array}$ & $\begin{array}{c}-14.244^{* * *} \\
(1.236)\end{array}$ & $\begin{array}{c}1.715^{* * *} \\
(0.343)\end{array}$ & $\begin{array}{c}-19.500^{* * *} \\
(0.604)\end{array}$ & $\begin{array}{c}1.825 \\
(1.285)\end{array}$ & $\begin{array}{c}1.336^{* * *} \\
(0.355)\end{array}$ & $\begin{array}{c}1.880 \\
(1.404)\end{array}$ & $\begin{array}{l}1.445^{* *} \\
(0.647)\end{array}$ \\
\hline Household wealth & $\begin{array}{c}0.015 \\
(0.201)\end{array}$ & $\begin{array}{l}-0.114 \\
(0.134)\end{array}$ & $\begin{array}{l}-0.038 \\
(0.096)\end{array}$ & $\begin{array}{l}0.568^{* *} \\
(0.279)\end{array}$ & $\begin{array}{l}-0.122 \\
(0.102)\end{array}$ & $\begin{array}{l}0.283^{*} \\
(0.156)\end{array}$ & $\begin{array}{l}-0.104 \\
(0.172)\end{array}$ & $\begin{array}{c}-0.206^{* *} \\
(0.099)\end{array}$ & $\begin{array}{c}0.784^{* * *} \\
(0.280)\end{array}$ & $\begin{array}{l}-0.309^{*} \\
(0.175)\end{array}$ \\
\hline Household size & $\begin{array}{c}0.028 \\
(0.063)\end{array}$ & $\begin{array}{l}-0.010 \\
(0.043)\end{array}$ & $\begin{array}{l}0.056^{* *} \\
(0.027)\end{array}$ & $\begin{array}{l}0.132^{*} \\
(0.067)\end{array}$ & $\begin{array}{l}0.071^{* *} \\
(0.031)\end{array}$ & $\begin{array}{l}-0.089 \\
(0.054)\end{array}$ & $\begin{array}{c}0.036 \\
(0.054)\end{array}$ & $\begin{array}{c}-0.110^{* * *} \\
(0.036)\end{array}$ & $\begin{array}{c}0.010 \\
(0.073)\end{array}$ & $\begin{array}{l}-0.026 \\
(0.056)\end{array}$ \\
\hline Female-headed hhd & $\begin{array}{l}-0.335 \\
(0.538)\end{array}$ & $\begin{array}{c}0.502 \\
(0.374)\end{array}$ & $\begin{array}{l}0.540^{*} \\
(0.285)\end{array}$ & $\begin{array}{c}1.125 \\
(0.800)\end{array}$ & $\begin{array}{l}0.626^{*} \\
(0.347)\end{array}$ & $\begin{array}{c}-20.387^{* * *} \\
(0.447)\end{array}$ & $\begin{array}{c}-20.766^{* * *} \\
(0.297)\end{array}$ & $\begin{array}{c}0.120 \\
(0.341)\end{array}$ & $\begin{array}{c}-19.632^{* * *} \\
(0.536)\end{array}$ & $\begin{array}{c}0.565 \\
(0.531)\end{array}$ \\
\hline Highest yrs. of ed. in hhd. & $\begin{array}{l}-0.060 \\
(0.072)\end{array}$ & $\begin{array}{c}-0.096^{* *} \\
(0.048)\end{array}$ & $\begin{array}{l}-0.003 \\
(0.035)\end{array}$ & $\begin{array}{l}-0.075 \\
(0.120)\end{array}$ & $\begin{array}{c}0.047 \\
(0.040)\end{array}$ & $\begin{array}{l}-0.076 \\
(0.050)\end{array}$ & $\begin{array}{c}0.015 \\
(0.051)\end{array}$ & $\begin{array}{l}0.084^{* *} \\
(0.035)\end{array}$ & $\begin{array}{l}-0.023 \\
(0.070)\end{array}$ & $\begin{array}{l}0.112^{* *} \\
(0.055)\end{array}$ \\
\hline Father reads \& writes & $\begin{array}{c}0.696 \\
(0.440)\end{array}$ & $\begin{array}{c}0.233 \\
(0.307)\end{array}$ & $\begin{array}{c}0.182 \\
(0.212)\end{array}$ & $\begin{array}{l}1.513^{*} \\
(0.870)\end{array}$ & $\begin{array}{c}0.092 \\
(0.218)\end{array}$ & $\begin{array}{c}0.007 \\
(0.252)\end{array}$ & $\begin{array}{c}0.147 \\
(0.250)\end{array}$ & $\begin{array}{c}0.170 \\
(0.150)\end{array}$ & $\begin{array}{c}0.354 \\
(0.315)\end{array}$ & $\begin{array}{c}0.041 \\
(0.242)\end{array}$ \\
\hline Father <intermediate & $\begin{array}{c}0.040 \\
(0.615)\end{array}$ & $\begin{array}{l}0.822^{* *} \\
(0.363)\end{array}$ & $\begin{array}{c}0.397 \\
(0.243)\end{array}$ & $\begin{array}{c}0.754 \\
(1.087)\end{array}$ & $\begin{array}{l}0.458^{*} \\
(0.240)\end{array}$ & $\begin{array}{c}0.217 \\
(1.328)\end{array}$ & $\begin{array}{c}1.348 \\
(1.029)\end{array}$ & $\begin{array}{c}0.567 \\
(0.752)\end{array}$ & $\begin{array}{c}-19.643^{* * *} \\
(0.862)\end{array}$ & $\begin{array}{c}0.734 \\
(0.802)\end{array}$ \\
\hline Father intermediate+ & $\begin{array}{c}0.547 \\
(0.530)\end{array}$ & $\begin{array}{c}0.499 \\
(0.345)\end{array}$ & $\begin{array}{c}0.327 \\
(0.237)\end{array}$ & $\begin{array}{l}2.098^{* *} \\
(0.946)\end{array}$ & $\begin{array}{c}0.128 \\
(0.241)\end{array}$ & $\begin{array}{l}0.725^{*} \\
(0.416)\end{array}$ & $\begin{array}{c}0.390 \\
(0.445)\end{array}$ & $\begin{array}{l}-0.323 \\
(0.271)\end{array}$ & $\begin{array}{c}0.625 \\
(0.699)\end{array}$ & $\begin{array}{c}0.212 \\
(0.396)\end{array}$ \\
\hline Father university+ & $\begin{array}{c}0.594 \\
(0.718)\end{array}$ & $\begin{array}{l}0.996^{* *} \\
(0.484)\end{array}$ & $\begin{array}{c}0.347 \\
(0.289)\end{array}$ & $\begin{array}{l}2.028^{*} \\
(1.140)\end{array}$ & $\begin{array}{c}0.361 \\
(0.310)\end{array}$ & $\begin{array}{l}1.188^{* *} \\
(0.519)\end{array}$ & $\begin{array}{c}0.022 \\
(0.756)\end{array}$ & $\begin{array}{l}-0.210 \\
(0.348)\end{array}$ & $\begin{array}{l}1.603^{* *} \\
(0.787)\end{array}$ & $\begin{array}{c}0.466 \\
(0.554)\end{array}$ \\
\hline Father employer & $\begin{array}{c}0.542 \\
(0.515)\end{array}$ & $\begin{array}{c}0.480 \\
(0.367)\end{array}$ & $\begin{array}{l}-0.007 \\
(0.284)\end{array}$ & $\begin{array}{l}1.495^{* *} \\
(0.663)\end{array}$ & $\begin{array}{l}-0.270 \\
(0.334)\end{array}$ & $\begin{array}{c}0.273 \\
(0.388)\end{array}$ & $\begin{array}{c}0.240 \\
(0.446)\end{array}$ & $\begin{array}{c}-0.569^{* *} \\
(0.246)\end{array}$ & $\begin{array}{c}0.487 \\
(0.588)\end{array}$ & $\begin{array}{c}0.164 \\
(0.437)\end{array}$ \\
\hline Father self-empl./unpaid fam. wrkr & $\begin{array}{l}0.856^{* *} \\
(0.349)\end{array}$ & $\begin{array}{c}0.230 \\
(0.246)\end{array}$ & $\begin{array}{l}-0.045 \\
(0.191)\end{array}$ & $\begin{array}{l}1.269^{* *} \\
(0.512)\end{array}$ & $\begin{array}{c}0.021 \\
(0.209)\end{array}$ & $\begin{array}{c}0.386 \\
(0.251)\end{array}$ & $\begin{array}{c}0.317 \\
(0.253)\end{array}$ & $\begin{array}{l}-0.256 \\
(0.165)\end{array}$ & $\begin{array}{l}0.809^{* *} \\
(0.316)\end{array}$ & $\begin{array}{c}-0.580^{* *} \\
(0.258)\end{array}$ \\
\hline employed & $\begin{array}{c}0.562 \\
(0.532)\end{array}$ & $\begin{array}{l}-0.447 \\
(0.502)\end{array}$ & $\begin{array}{l}-0.275 \\
(0.308)\end{array}$ & $\begin{array}{c}0.955 \\
(0.874)\end{array}$ & $\begin{array}{l}-0.421 \\
(0.390)\end{array}$ & $\begin{array}{l}-0.138 \\
(0.556)\end{array}$ & $\begin{array}{c}0.281 \\
(0.520)\end{array}$ & $\begin{array}{c}0.117 \\
(0.291)\end{array}$ & $\begin{array}{c}0.460 \\
(0.945)\end{array}$ & $\begin{array}{c}0.073 \\
(0.542)\end{array}$ \\
\hline Rural residence & $\begin{array}{l}-0.657^{*} \\
(0.356)\end{array}$ & $\begin{array}{c}-0.841^{* * *} \\
(0.236)\end{array}$ & $\begin{array}{c}0.200 \\
(0.132)\end{array}$ & $\begin{array}{l}-0.556 \\
(0.596)\end{array}$ & $\begin{array}{l}-0.002 \\
(0.150)\end{array}$ & $\begin{array}{l}-0.376^{*} \\
(0.225)\end{array}$ & $\begin{array}{c}-0.739^{* * *} \\
(0.249)\end{array}$ & $\begin{array}{l}-0.021 \\
(0.140)\end{array}$ & $\begin{array}{c}-1.180^{* * *} \\
(0.384)\end{array}$ & $\begin{array}{c}-0.531^{* *} \\
(0.239)\end{array}$ \\
\hline North region & $\begin{array}{c}-0.384 \\
(0.292)\end{array}$ & $\begin{array}{l}-0.254 \\
(0.211)\end{array}$ & $\begin{array}{c}0.472^{* * *} \\
(0.140)\end{array}$ & $\begin{array}{c}0.667 \\
(0.444)\end{array}$ & $\begin{array}{c}0.730^{* * *} \\
(0.165)\end{array}$ & $\begin{array}{c}0.208 \\
(0.213)\end{array}$ & $\begin{array}{c}-0.536^{* *} \\
(0.239)\end{array}$ & $\begin{array}{c}0.549^{* * *} \\
(0.142)\end{array}$ & $\begin{array}{c}0.878^{* * *} \\
(0.295)\end{array}$ & $\begin{array}{c}1.173^{* * *} \\
(0.260)\end{array}$ \\
\hline South region & $\begin{array}{l}-0.860^{*} \\
(0.510)\end{array}$ & $\begin{array}{l}-0.377 \\
(0.344)\end{array}$ & $\begin{array}{c}1.242^{* * *} \\
(0.209)\end{array}$ & $\begin{array}{l}1.841^{* *} \\
(0.807)\end{array}$ & $\begin{array}{c}1.698^{* * *} \\
(0.247)\end{array}$ & $\begin{array}{l}-0.617 \\
(0.417)\end{array}$ & $\begin{array}{c}-1.420^{* * *} \\
(0.397)\end{array}$ & $\begin{array}{l}0.413^{*} \\
(0.212)\end{array}$ & $\begin{array}{l}-0.601 \\
(0.471)\end{array}$ & $\begin{array}{c}1.077^{* * *} \\
(0.309)\end{array}$ \\
\hline Constant & $\begin{array}{c}-3.754^{* * *} \\
(1.127)\end{array}$ & $\begin{array}{l}-0.819 \\
(0.849)\end{array}$ & $\begin{array}{c}-2.787^{* * * *} \\
(0.725)\end{array}$ & $\begin{array}{c}-8.310^{* * *} \\
(1.796)\end{array}$ & $\begin{array}{l}-0.849 \\
(0.730)\end{array}$ & $\begin{array}{l}-3.707^{*} \\
(2.182)\end{array}$ & $\begin{array}{l}-2.549 \\
(1.678)\end{array}$ & $\begin{array}{c}-3.439^{* * *} \\
(1.147)\end{array}$ & $\begin{array}{c}-8.237^{* *} \\
(3.220)\end{array}$ & $\begin{array}{l}-2.253^{*} \\
(1.221)\end{array}$ \\
\hline Obser & 3,597 & 3,597 & 3,597 & 3,597 & 3,597 & 3,429 & 3,429 & 3,429 & 3,429 & 3,429 \\
\hline Chi-squared & 4896 & 4896 & 4896 & 4896 & 4896 & 33949 & 33949 & 33949 & 33949 & 33949 \\
\hline Pseudo R-squared & 0.241 & 0.241 & 0.241 & 0.241 & 0.241 & 0.287 & 0.287 & 0.287 & 0.287 & 0.287 \\
\hline
\end{tabular}

Note: samples weighted using individual-level weights. Standard errors robust to arbitrary heteroskedasticity are in parentheses, ${ }^{* * *} p<0.01,{ }^{* *} p<0.05,{ }^{*} p<0.1$. Workers' status as 'youth' and all household-level variables are lagged by one survey wave to estimate the effect of workers' circumstances in their youth on their subsequent outcomes.

Source: authors' calculations based on JLMPS 2010-16 (OAMDI 2019). 
Table 4: Multinomial logit regressions on TLMPS14, separating youth and non-youth

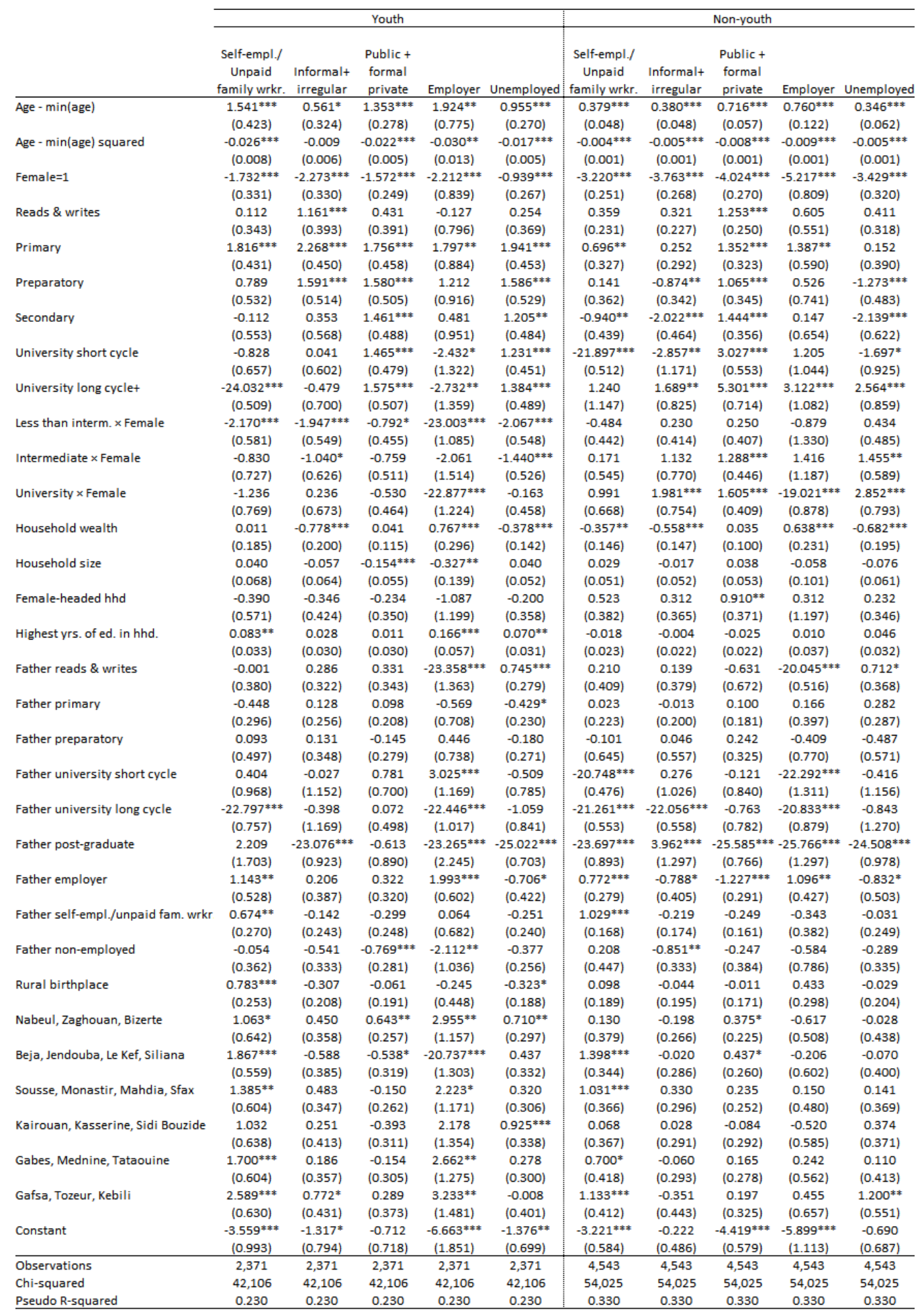

Note: samples weighted using individual-level weights. Standard errors robust to arbitrary heteroskedasticity are in parentheses, ${ }^{\star * \star} p<0.01,{ }^{\star *} p<0.05,{ }^{*} p<0.1$. Workers' status as 'youth' is lagged by six years (i.e. 'youth' are 21-35 years old in 2014) and region and rural/urban residence are from workers' birthplace to estimate the effect of workers' circumstances in their youth on their subsequent outcomes.

Source: authors' calculations based on TLMPS 2014 (OAMDI 2019). 
Figure 1: Employment sector transitions, male non-student youth
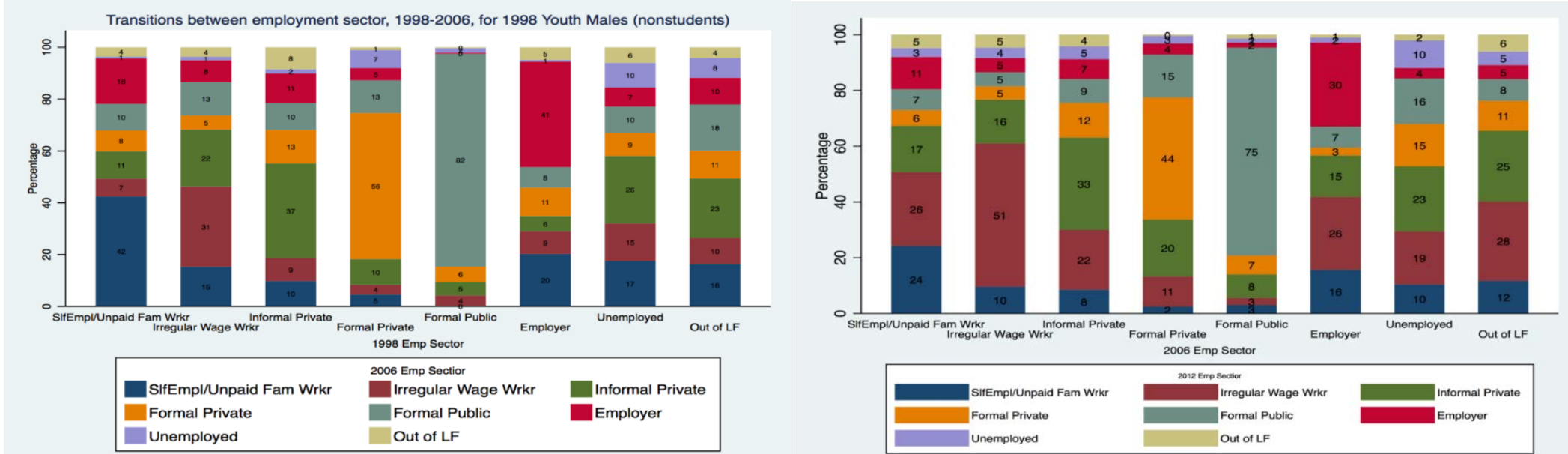

i. 1998-2006 Egypt

ii. 2006-12 Egypt
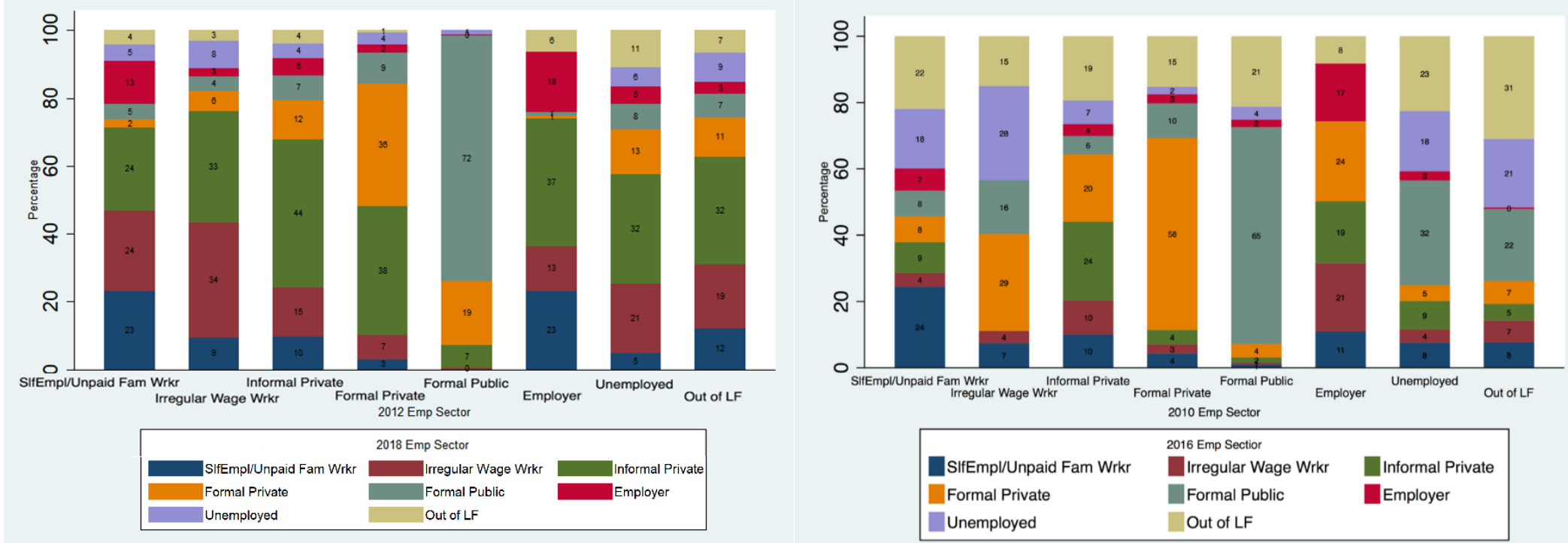

iv. 2010-16 Jordan 


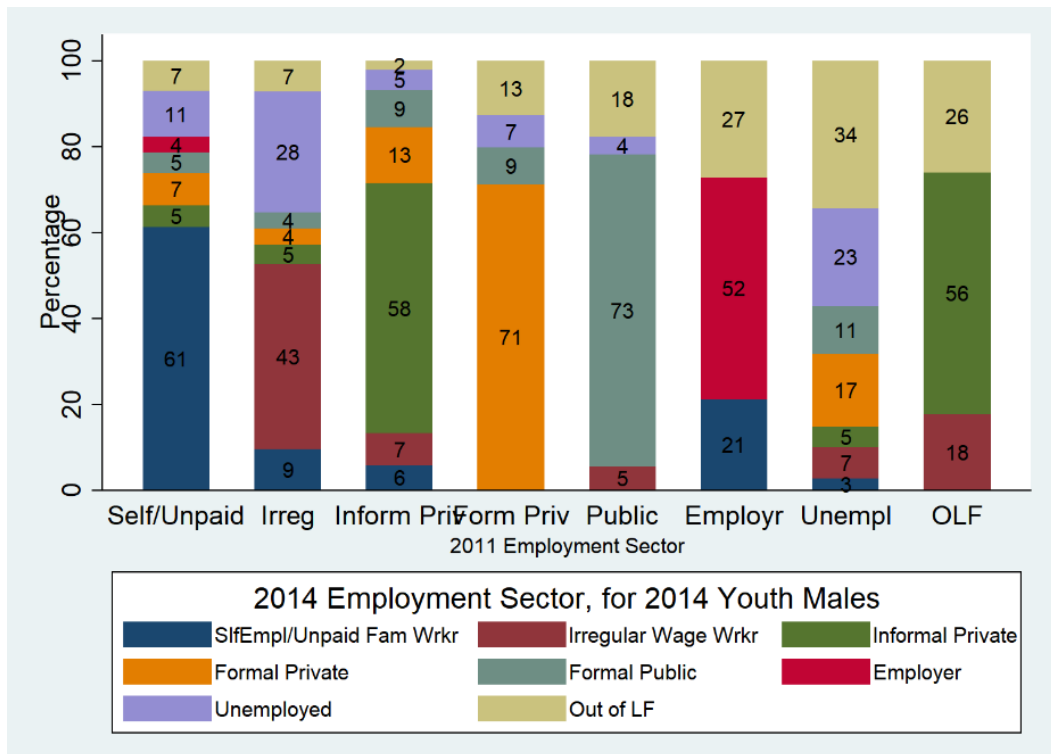

v. 2011-14 Tunisia

Source: authors' illustrations based on ELMPS 1998-2018, JLMPS 2010-2016, TLMPS 2014 (OAMDI 2019). 
Figure 2: Employment sector by household wealth quintiles, for youth males
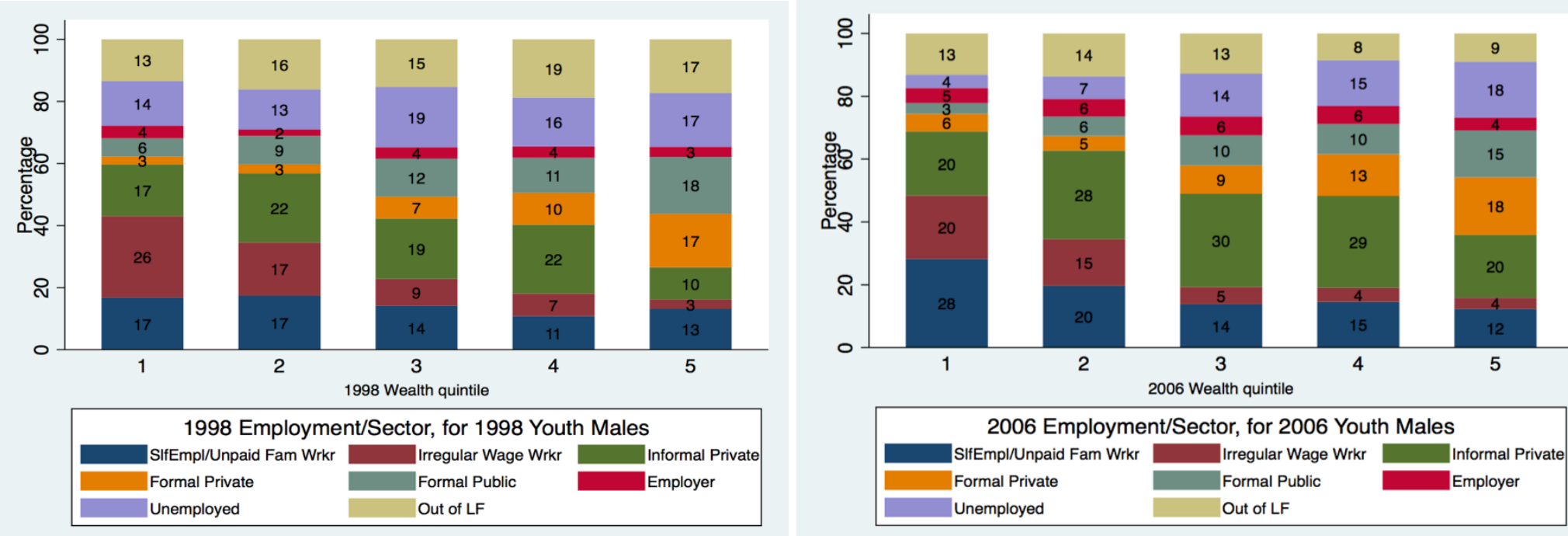

i. 1998 Egypt

ii. 2006 Egypt
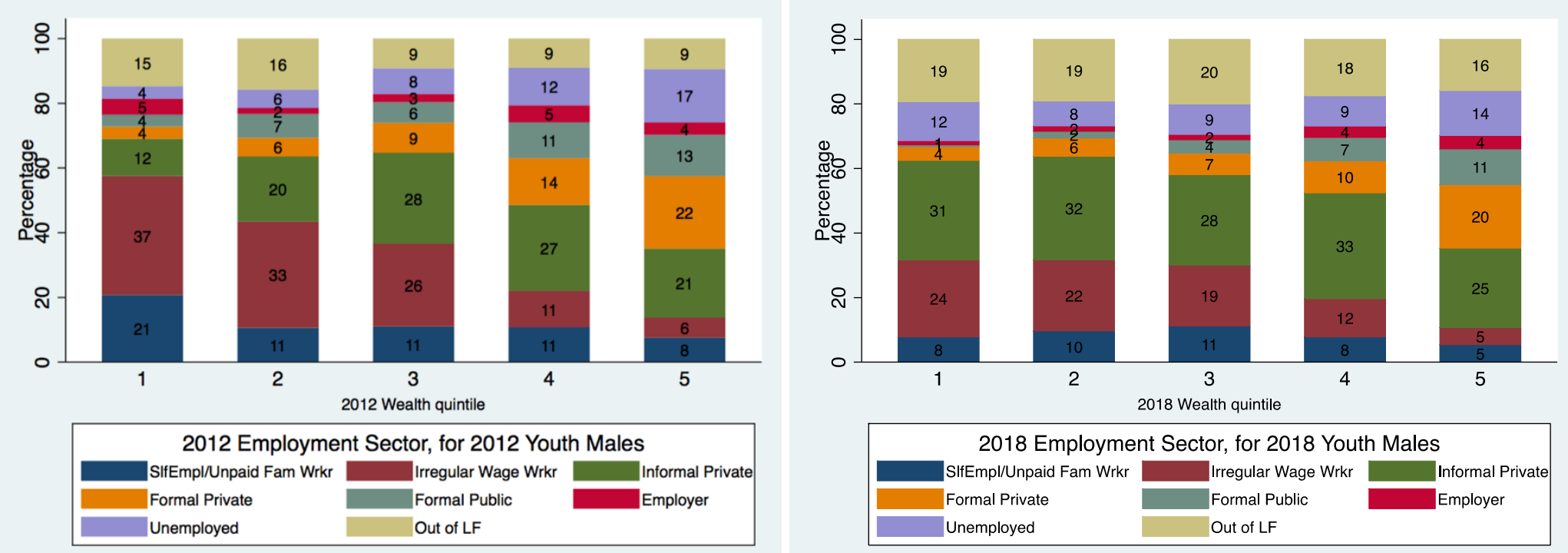

2018 Employment Sector, for 2018 Youth Males

\begin{tabular}{|l|l|l|}
\hline SlfEmp//Unpaid Fam Wrkr & Irregular Wage Wrkr & Informal Private \\
\hline Formal Private & Formal Public & Employer \\
\hline Unemployed & Out of LF & \\
\hline
\end{tabular}

iii. 2012 Egypt

iv. 2018 Egypt 


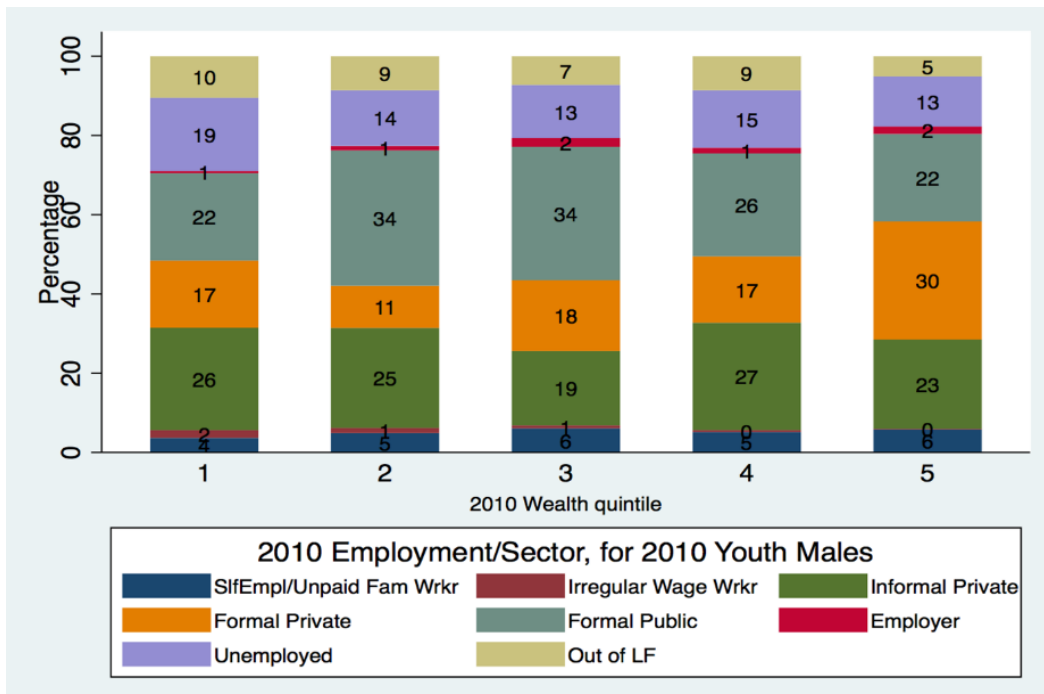

v. 2010 Jordan

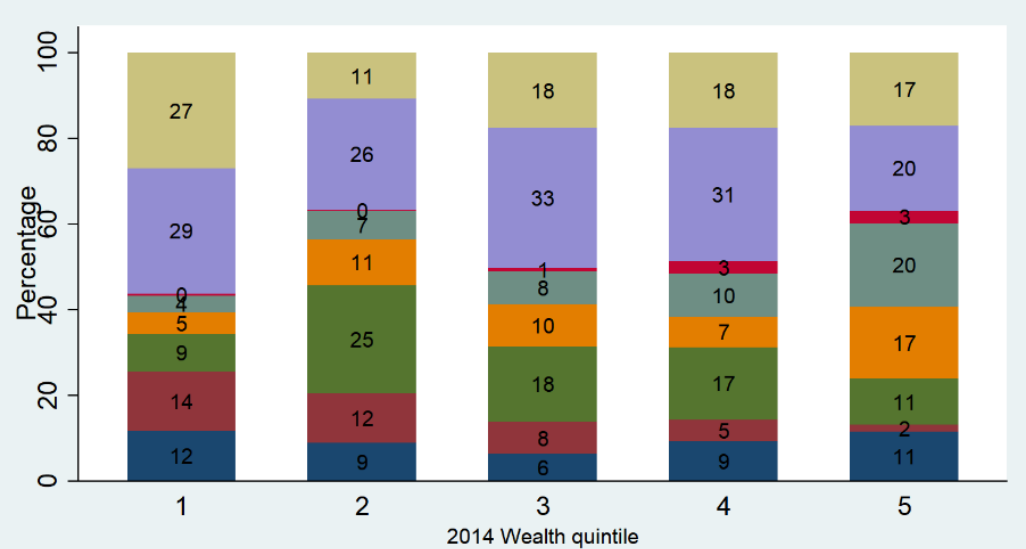

2014 Employment Sector, for 2014 Youth Males

\begin{tabular}{|l|l|l|}
\hline SIfEmpl/Unpaid Fam Wrkr & Irregular Wage Wrkr & Informal Private \\
\hline Formal Private & Formal Public & Employer \\
\hline Unemployed & Out of LF & \\
\hline
\end{tabular}

vii. 2014 Tunisia

Source: authors' illustrations based on ELMPS 1998-2018, JLMPS 2010-2016, TLMPS 2014 (OAMDI 2019).

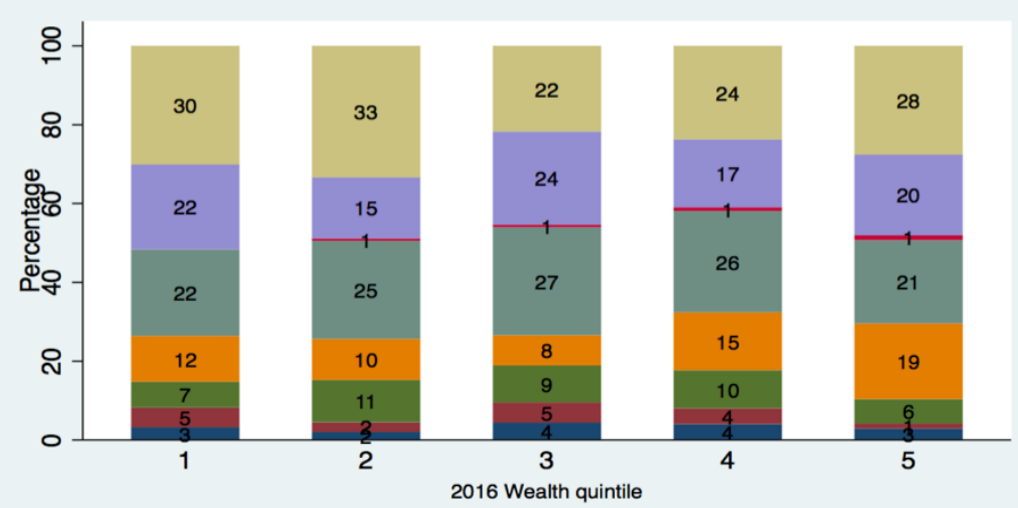

2016 Employment Sector, for 2016 Youth Males

\begin{tabular}{|l|l|l|}
\hline SlfEmpl/Unpaid Fam Wrkr & Irregular Wage Wrkr & Informal Private \\
Formal Private & Formal Public & Employer \\
Unemployed & Out of LF & \\
\hline
\end{tabular}

vi. 2016 Jordan 
Figure 3: Employment sector by father's education, for youth males

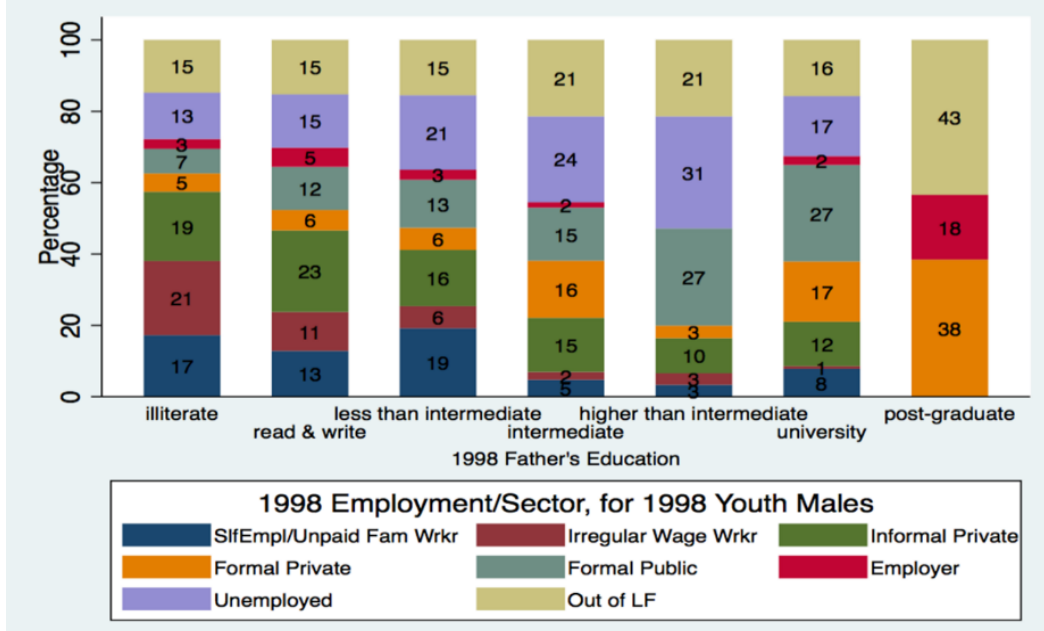

i. 1998 Egypt

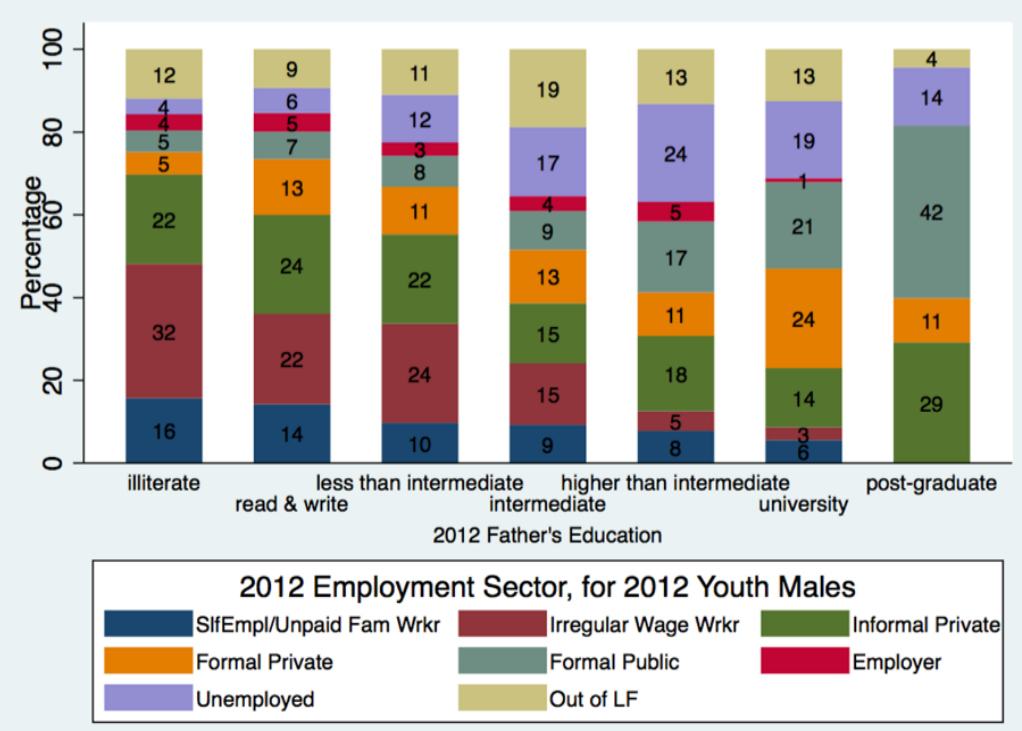

iii. 2012 Egypt

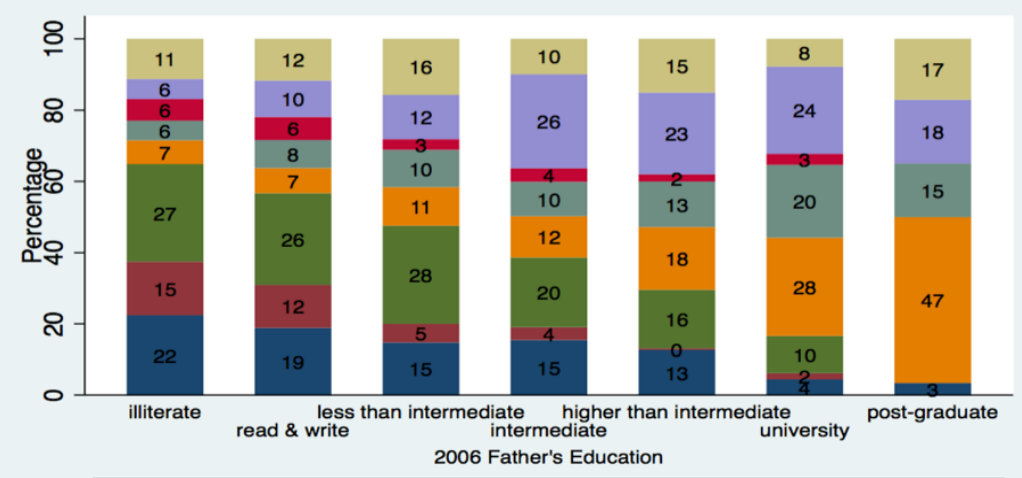

2006 Employment Sector, for 2006 Youth Males

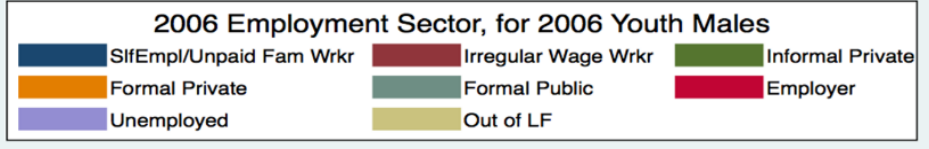

ii. 2006 Egypt

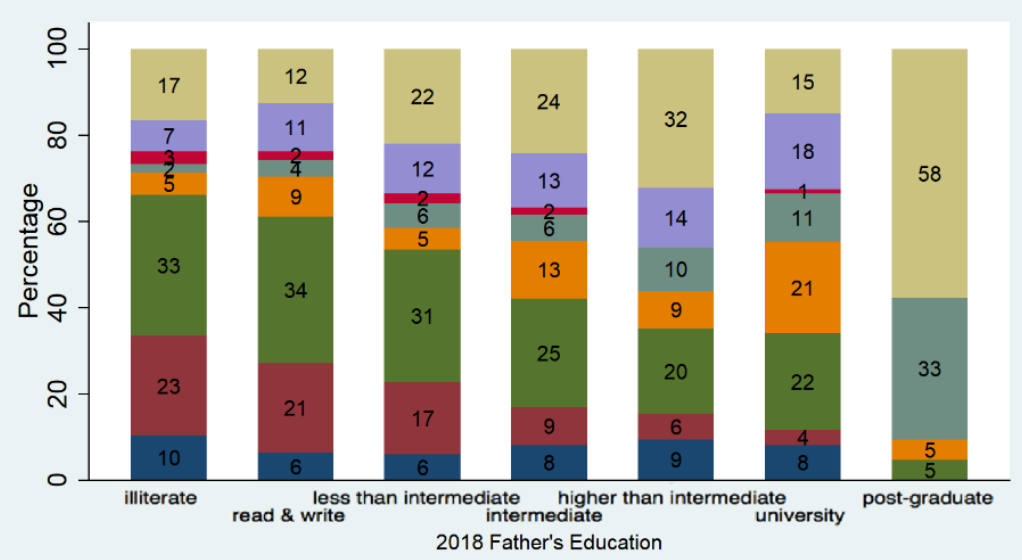

2018 Employment Sector, for 2018 Youth Males

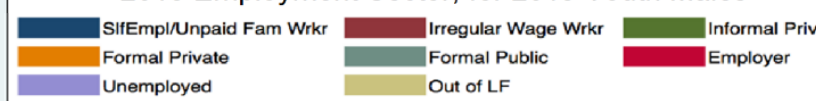

iv. 2018 Egypt 


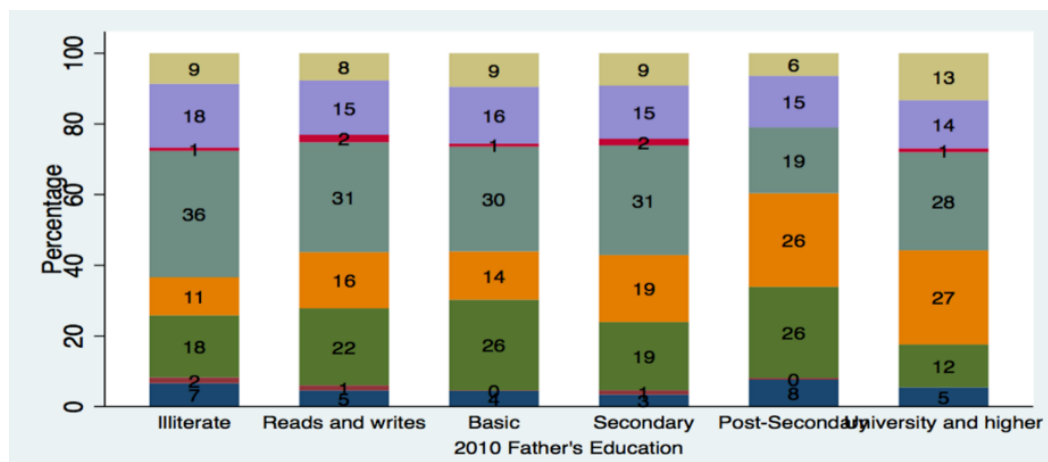

2010 Employment Sector, for 2010 Youth Males

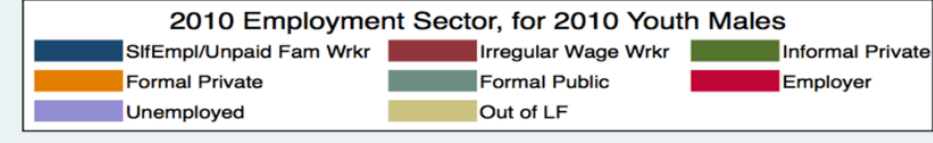

v. 2010 Jordan

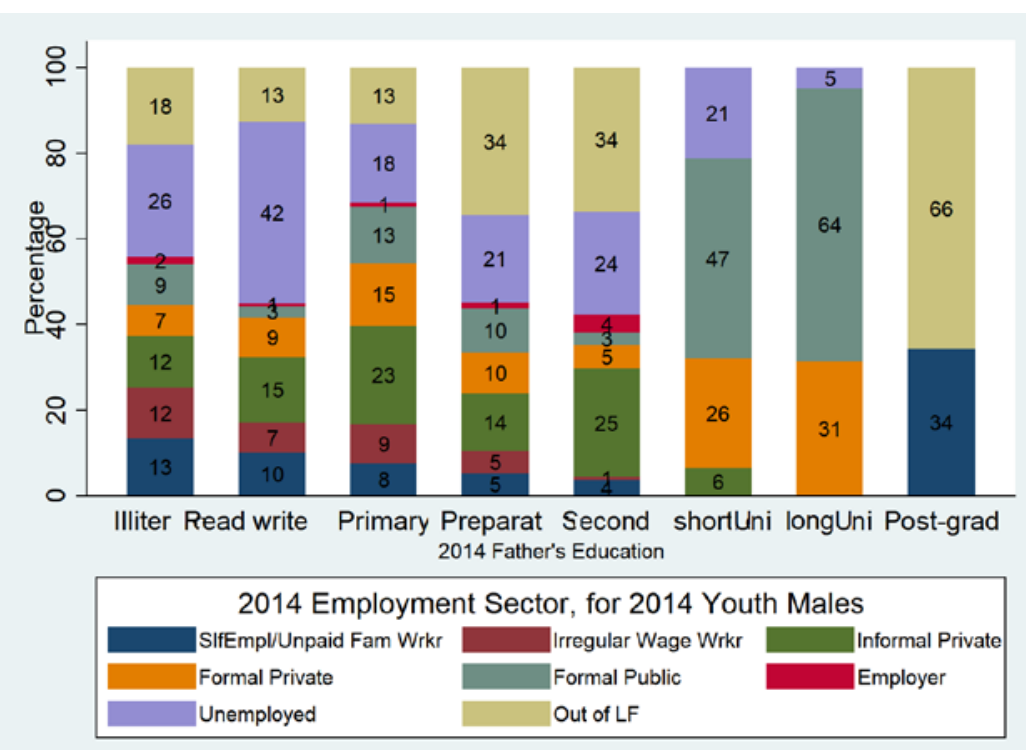

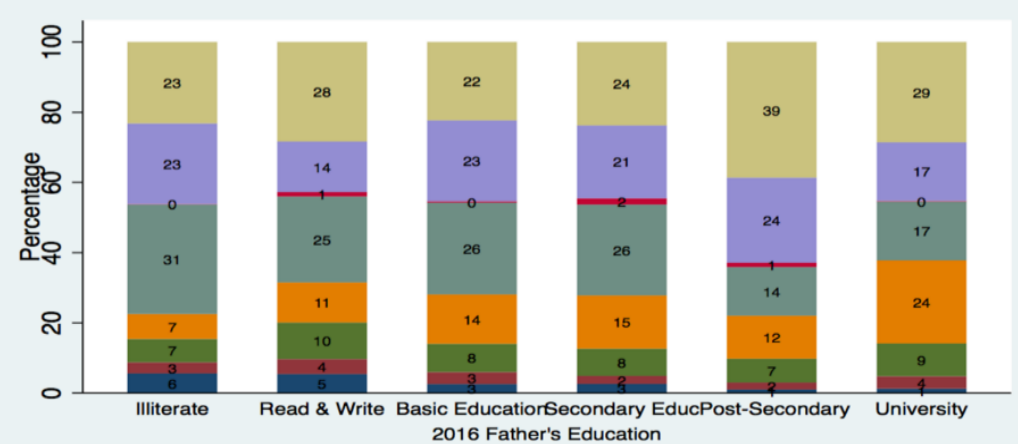

2016 Employment Sector, for 2016 Youth Males

\begin{tabular}{|l|l|l|}
\hline \multicolumn{2}{|c|}{2016 Employment Sector, for 2016 Youth Males } \\
SIfEmpl/Unpaid Fam Wrkr & Irregular Wage Wrkr & Informal Private \\
Formal Private & Formal Public & Employer \\
Unemployed & Out of LF \\
\hline
\end{tabular}

vi. 2016 Jordan

\section{vii. 2014 Tunisia}

Source: authors' illustrations based on ELMPS 1998-2018, JLMPS 2010-2016, TLMPS 2014 (OAMDI 2019). 
Figure 4: Predicted probability of employment type by age and gender

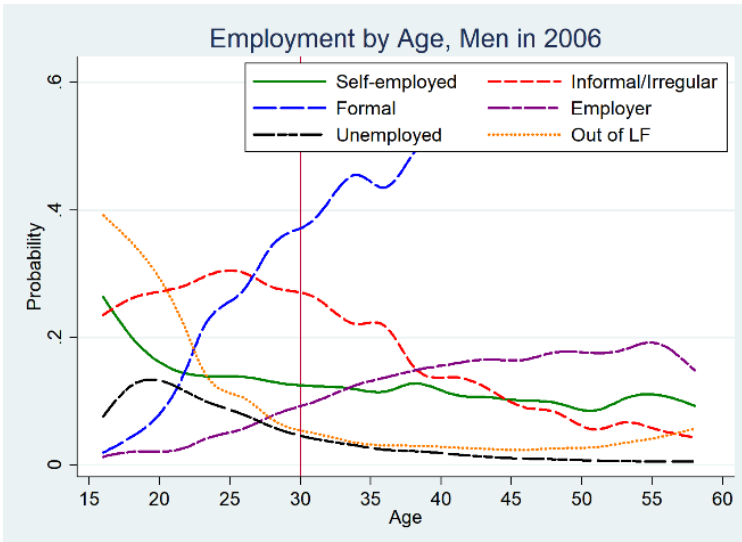

i. ELMPS06 Men

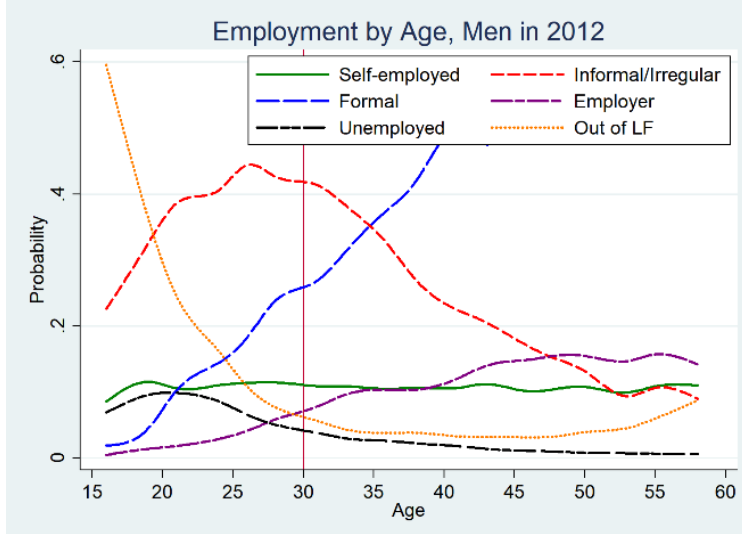

iii. ELMPS12 Men

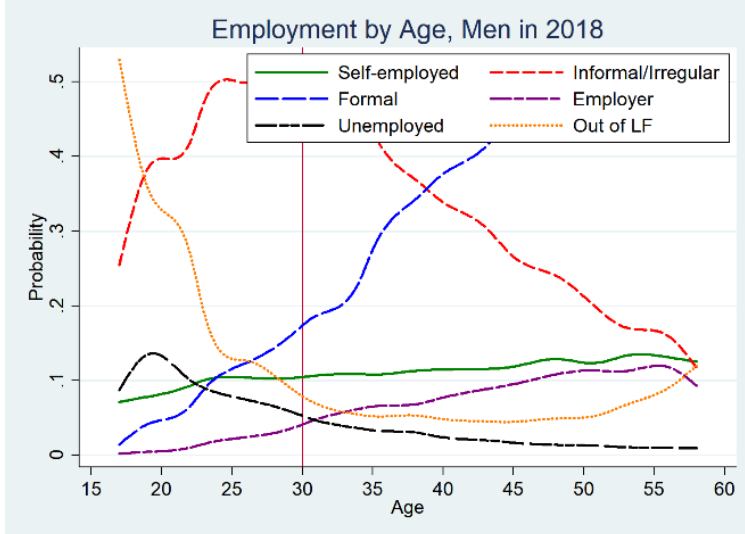

v. ELMPS18 Men

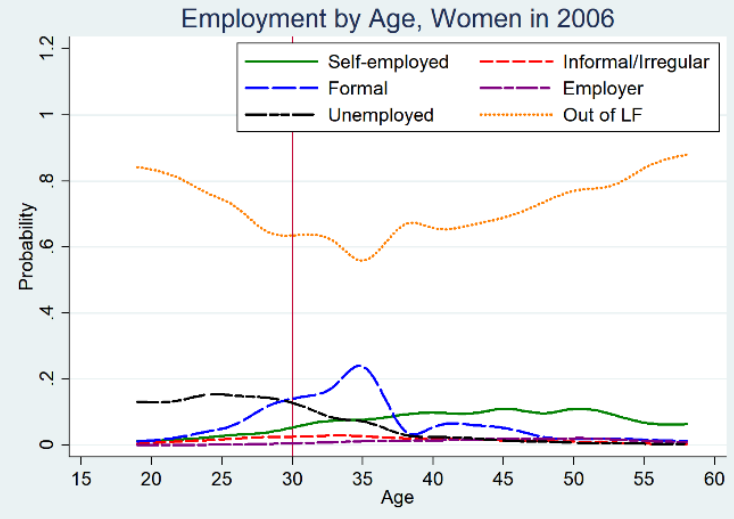

ii. ELMPS06 Women

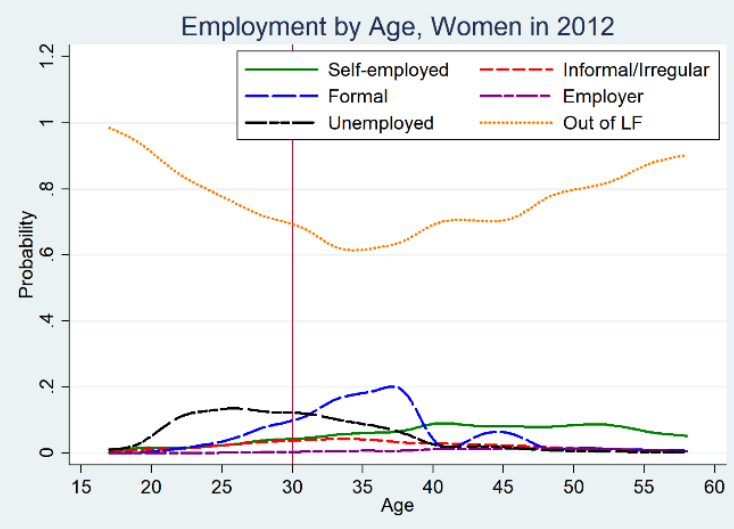

iv. ELMPS12 Women

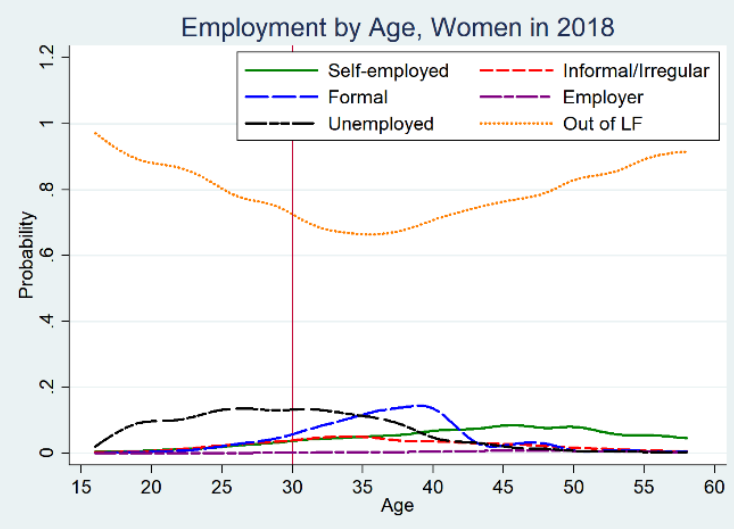

vi. ELMPS18 Women 


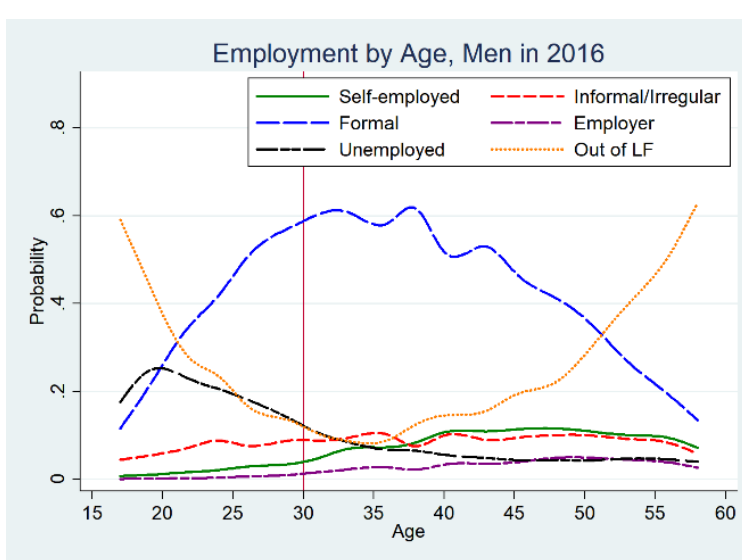

vii. JLMPS16 Men

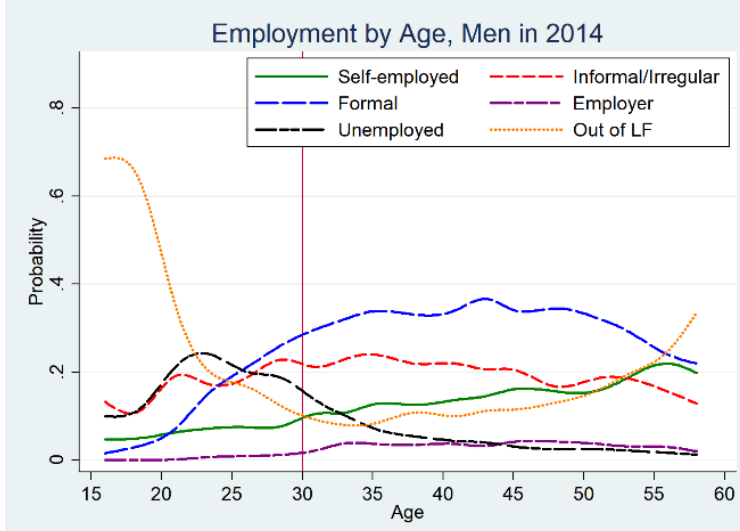

ix. TLMPS14 Men

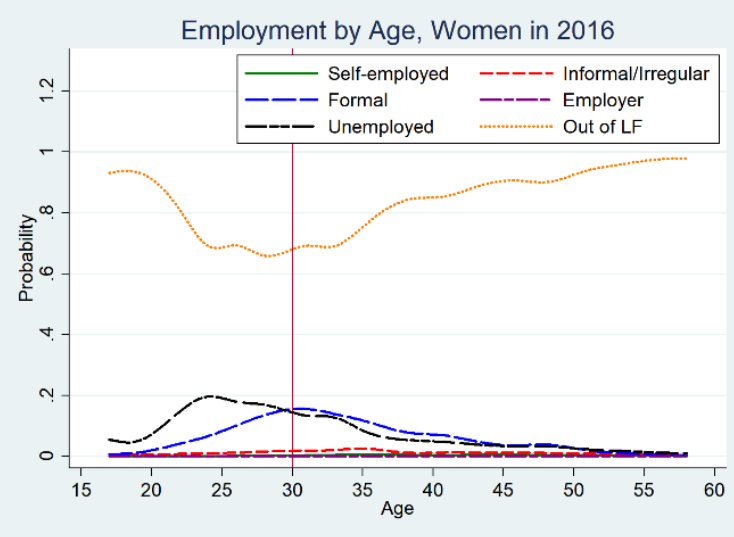

viii. JLMPS16 Women

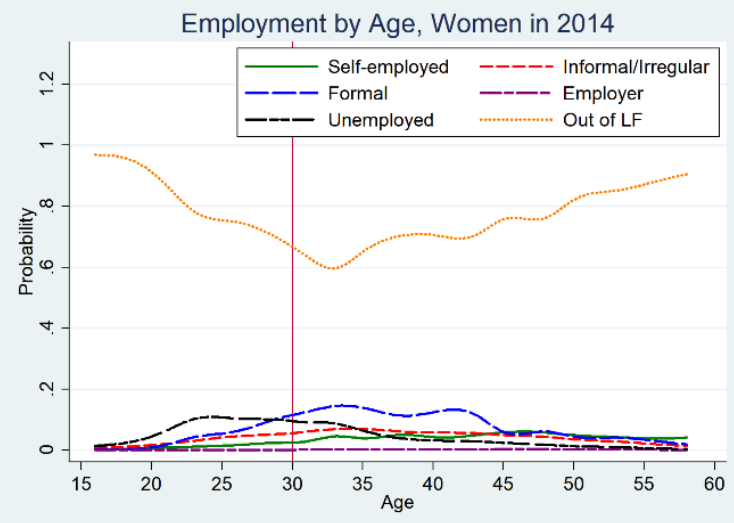

x. TLMPS14 Women

Source: authors' illustrations based on ELMPS 2006-2018, JLMPS 2016, TLMPS 2014 (OAMDI 2019). 
Figure 5: Predicted probability of transition from vulnerability among men, by age

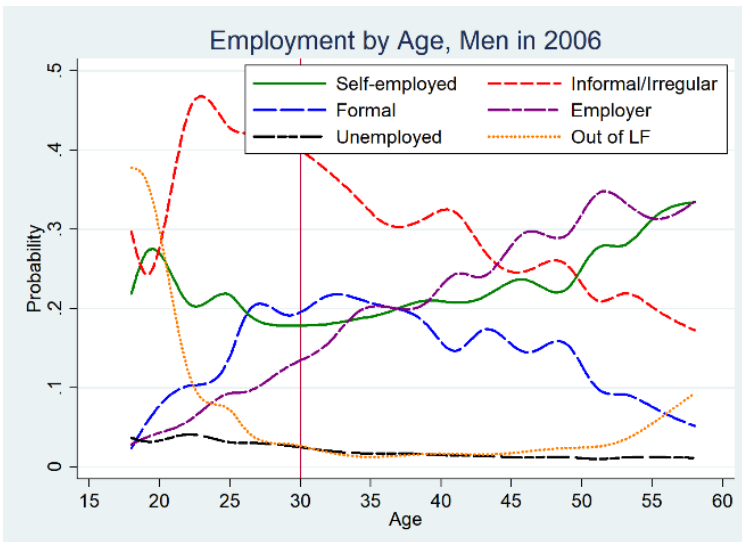

i. ELMPS06 Men

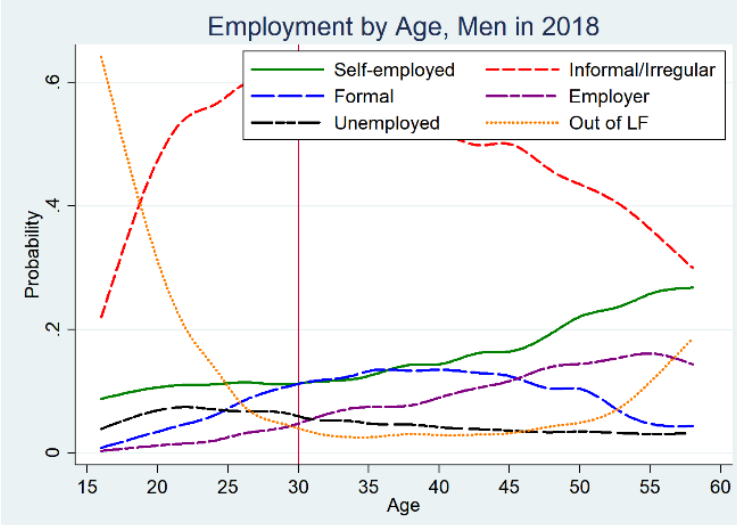

iii. ELMPS18 Men

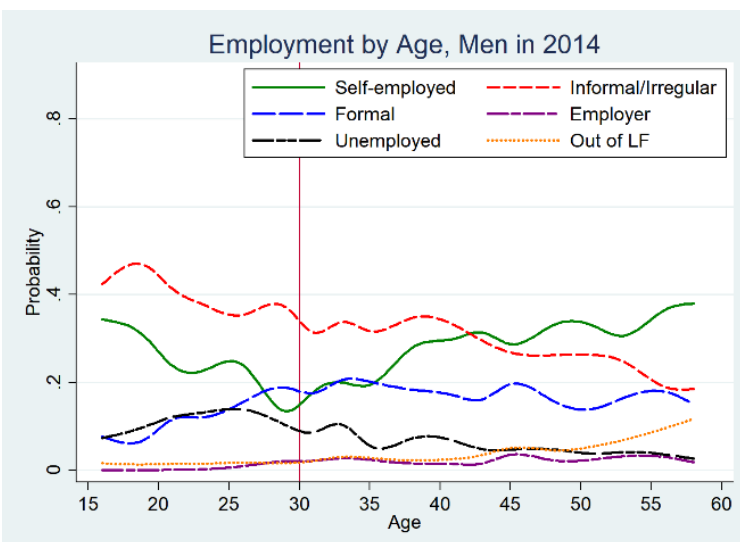

iii. TLMPS14 Men

Source: authors' illustrations based on ELMPS 2006-2018, JLMPS 2016, TLMPS 2014 (OAMDI 2019).
Employment by Age, Men in 2012

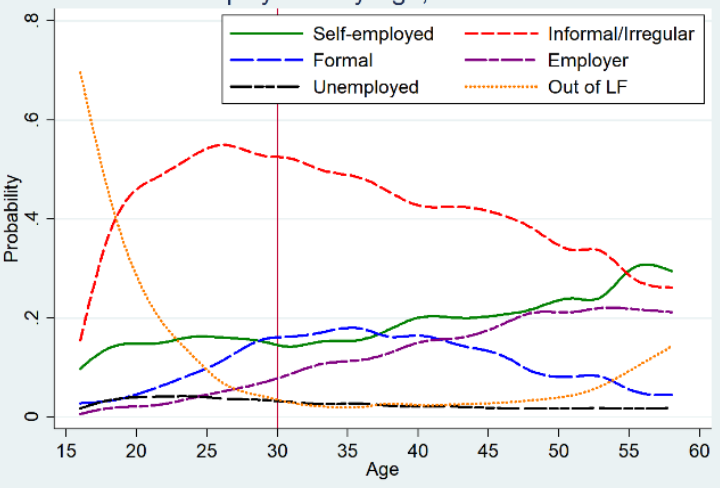

ii. ELMPS12 Men

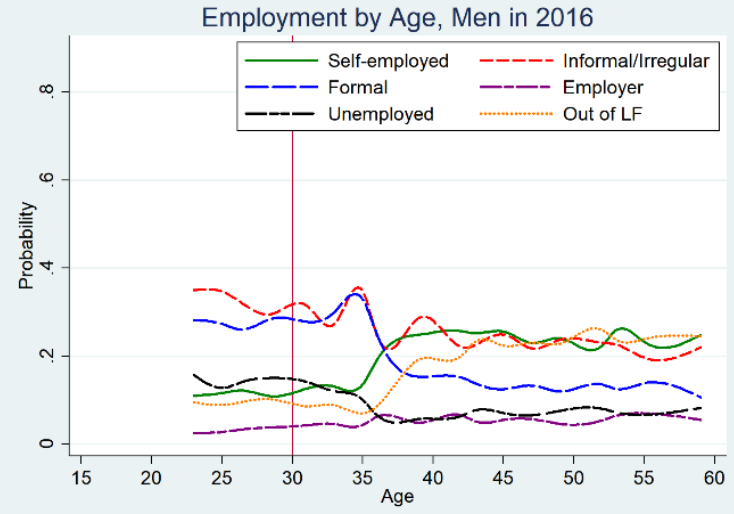

iv. JLMPS16 Men 


\section{Appendix}

\section{A Data descriptive statistics and additional results}

The Labour Market Panel Survey (LMPS) datasets are rich with measures that describe householdlevel socio-economic characteristics that could be responsible for workers' outcomes at future period(s). This includes households' total earnings, their stock of productive and non-productive assets (combined into a wealth index), parents' education and employment status, as well as a variety of other labour market and demographic characteristics. We also explore the role of individual characteristics such as educational attainment and other demographic factors in one period on outcome variables at a future period. Table 1 presents summary statistics for each period, differentiating between youths and those who were 25 to 64 years old. ${ }^{9}$ We also present statistics for those who were youths in 1998, in the years 2006 and 2012; and for those who were youths in 2006 , in the year 2012.

Our outcome variables of interest are individual earnings relative to a low earnings line (henceforth LEL), relative wealth based on an index of wealth that captures the household's stock of productive and non-productive assets, and an index of job quality that captures a number of aspects of non-monetary job characteristics such as the existence of a contract, paid leave (sick or otherwise), job stability, social insurance, and medical insurance.

The labour market outcomes that we will focus on for this study are individual and family labour market earnings (relative to a LEL), educational achievement, wealth, and job quality. These outcomes are closely related, but they measure somewhat different aspects of wellbeing, and form of disparity and vulnerability. They are also subject to various measurement issues. ${ }^{10}$

\section{Monetary measures of vulnerability}

The LMPS have detailed information on earnings and wages for wage workers during all years. We use monthly earnings in the primary job as a measure of individual welfare. ${ }^{11}$ Typically, each worker supports several other family members through their earnings, and their welfare will ultimately depend on how many other earners there are in the family as well as how many dependents are being supported. Comparing individual income to a per capita monthly poverty line can therefore overestimate the overall welfare of the household and, by extension, individuals living within it, as those earnings are not solely spent on the individual worker's needs. We therefore also use total

\footnotetext{
${ }^{9}$ Throughout the paper, we limit all our analysis to the working age population (15-64).

${ }^{10}$ Earnings may be more accurately reported than consumption expenditures since they are easier to recall. Using earnings is also usually the only way we can identify the source of any mobility, whether it is due to demographic or economic events (Woolard and Klasen 2005). Household consumption per adult equivalent may be a better indicator of permanent income, welfare, and long-term mobility when households engage in consumption smoothing (Deaton 1997). To identify individuals falling below the poverty line, poverty thresholds from World Bank (2007), updated using the Consumer Price Index (CPI) were used for Egypt. To compute a LEL based on this poverty line we multiply the per capita poverty threshold by the number of dependents in each household since each earner typically supports more than one household member.

${ }^{11}$ To compare these earnings to an acceptable welfare benchmark, we could construct a Low Earnings Line that is derived from official poverty lines (PLs) in CAPMAS (2018). For LEL, the annual per capita PL should be divided by 12. These poverty lines were originally constructed in collaboration with the World Bank (2007) and are based on the cost-of-basic-needs methodology, accounting for differences in consumption trends and prices across regions in the case of Egypt.
} 
family earnings from all jobs as an additional monetary measure of vulnerability and compare it to a Family LEL. The Family LEL takes into consideration the fact that each working family member supports a number of dependents. The monthly PL is scaled up by each household's dependency ratio (computed as the ratio of total household members to working-age employed members) to obtain the Family LEL (each family will have its own unique LEL based on its dependency ratio). These LELs and corresponding monthly PLs are summarized in Table A2.

Table A3 reports results of static vulnerability by each of our monetary and non-monetary measures, both for youths (age 15 to 24) and those who were 25+ in each of the three years of the data for Egypt and Jordan (Table A4 shows this for Tunisia). The first two panels report the static monetary vulnerability using the individual earnings measure compared to the monthly PL, as well as the total family earnings compared the Family LEL, as explained above. In 1998, about one in four youth workers were earning below the individual LEL, about 2.8 times the average for those above 25 years of age. In 2006, the share of earnings-vulnerable youths fell to 21 per cent, but was still about three times that of non-youths and, in 2012, 13.5 per cent of the youths were earnings vulnerable, about twice as much as for non-youth workers. Nevertheless, these numbers mask the fact that most workers support a number of dependents and we therefore also look at total family earnings compared to the Family LEL described above. The share of vulnerable workers (youths and otherwise) rises in all years once dependents are taken into consideration. The share of vulnerable youths ranges from 57 per cent in 1998 to 42 per cent in 2006 and 2012. 
Table A1a: Summary statistics of 1998 Egyptian youth in 1998, 2006, 2012, and 2018

\begin{tabular}{|c|c|c|c|c|c|c|c|c|c|c|c|c|}
\hline \multirow{3}{*}{$\begin{array}{l}\text { Age Grp in } \\
1998\end{array}$} & \multicolumn{3}{|c|}{1998} & \multicolumn{3}{|c|}{2006} & \multicolumn{3}{|c|}{2012} & \multicolumn{3}{|c|}{2018} \\
\hline & $\begin{array}{l}\text { Age } 30 \\
\text { to } 59\end{array}$ & $\begin{array}{l}\text { Youth: } \\
15 \text { to } 29\end{array}$ & Total & $\begin{array}{l}\text { Age } 30 \\
\text { to } 59\end{array}$ & $\begin{array}{l}\text { Youth: } \\
15 \text { to } 29\end{array}$ & Total & $\begin{array}{l}\text { Age } 30 \\
\text { to } 59\end{array}$ & $\begin{array}{l}\text { Youth: } \\
15 \text { to } 29\end{array}$ & Total & $\begin{array}{l}\text { Age } 30 \\
\text { to } 59\end{array}$ & $\begin{array}{l}\text { Youth: } \\
15 \text { to } 29\end{array}$ & Total \\
\hline & $\%$ & $\%$ & $\%$ & $\%$ & $\%$ & $\%$ & $\%$ & $\%$ & $\%$ & $\%$ & $\%$ & $\%$ \\
\hline \multicolumn{13}{|c|}{ Educational Attainment (7 Categories, age $6+$ ) } \\
\hline Illiterate & 36.7 & 14.7 & 26.1 & 39.7 & 15.1 & 28 & 41.6 & 16.8 & 29.3 & 39.5 & 20.2 & 28.7 \\
\hline Reads\&Writes & 11.1 & 3.8 & 7.6 & 8 & 3.6 & 5.9 & 5.6 & 3.8 & 4.7 & 8.6 & 5.5 & 6.9 \\
\hline Less than Inte & 15.2 & 35.9 & 25.2 & 15 & 14.2 & 14.6 & 15.6 & 15.2 & 15.4 & 12.2 & 12.2 & 12.2 \\
\hline Intermediate & 17.7 & 35 & 26.1 & 19.6 & 39.7 & 29.2 & 20.8 & 38.4 & 29.6 & 23.7 & 39.1 & 32.4 \\
\hline Above Interme & 5.3 & 4.1 & 4.7 & 3.9 & 5.1 & 4.4 & 3 & 4.4 & 3.7 & 3.1 & 3.8 & 3.5 \\
\hline University & 13.2 & 6.4 & 9.9 & 13.1 & 22 & 17.3 & 12.5 & 20.4 & 16.5 & 12.1 & 18 & 15.4 \\
\hline post-graduate & 0.8 & 0.1 & 0.5 & 0.7 & 0.4 & 0.5 & 0.8 & 1 & 0.9 & 0.8 & 1.2 & 1 \\
\hline \multicolumn{13}{|c|}{ Work status during ref. 3 -month, market def. (search is not required) } \\
\hline Employed & 58.1 & 30.1 & 44.6 & 57.9 & 55.3 & 56.6 & 52.9 & 62.6 & 57.8 & 46.8 & 63.1 & 56.2 \\
\hline Unemployed & 1.9 & 11.2 & 6.4 & 0.6 & 9.5 & 4.9 & 0.6 & 5.8 & 3.3 & 0.8 & 4.7 & 3 \\
\hline Out of Labor $F$ & 40.1 & 58.7 & 49.1 & 41.5 & 35.2 & 38.5 & 46.6 & 31.6 & 38.9 & 52.4 & 32.2 & 40.8 \\
\hline & & & & & & & & & & & & \\
\hline \multicolumn{13}{|c|}{ Employment status of prim. Job (ref. 3-month) } \\
\hline wage worker & 62.3 & 58 & 60.8 & 56.6 & 63.1 & 59.6 & 61.9 & 70.5 & 66.6 & 59.2 & 67.7 & 64.6 \\
\hline employer & 9.5 & 2.8 & 7.2 & 15.3 & 7.8 & 11.8 & 14 & 9.5 & 11.5 & 9.5 & 6.3 & 7.5 \\
\hline self employed & 8.4 & 3.5 & 6.7 & 10 & 8.2 & 9.2 & 11.9 & 9.3 & 10.5 & 13.6 & 10.4 & 11.6 \\
\hline unpaid family & 19.8 & 35.7 & 25.2 & 18.1 & 20.8 & 19.3 & 12.1 & 10.7 & 11.4 & 17.7 & 15.6 & 16.3 \\
\hline & & & & & & & & & & & & \\
\hline \multicolumn{13}{|c|}{ Economic sector of prim. Job (ref. 3-month) } \\
\hline government & 35.5 & 13.8 & 28.1 & 36 & 19 & 28.1 & 41.6 & 25.3 & 32.7 & 38.3 & 26.1 & 30.6 \\
\hline public enterpr & 8.1 & 2.7 & 6.3 & 6.4 & 3.9 & 5.2 & 3.7 & 3.6 & 3.6 & 2.1 & 2.2 & 2.1 \\
\hline private & 55.3 & 82.5 & 64.6 & 56.2 & 75.2 & 65.1 & 53.3 & 68.8 & 61.7 & 59.5 & 70.7 & 66.6 \\
\hline jopint-venture & 0.8 & 0.7 & 0.8 & 1.2 & 1.4 & 1.3 & 0.8 & 1.8 & 1.3 & 0 & 0.9 & 0.6 \\
\hline foreign & 0.1 & 0.2 & 0.1 & o & 0.1 & o & o & 0.1 & o & 0 & 0 & 0 \\
\hline other & 0.2 & 0.2 & 0.2 & 0.2 & 0.3 & 0.3 & 0.6 & 0.5 & 0.6 & 0.1 & 0 & 0.1 \\
\hline & & & & & & & & & & & & \\
\hline \multicolumn{13}{|c|}{ Occup. of prim. job (1-digit based on ISCO88, ref. 3-month) } \\
\hline Managers & 12.3 & 2.9 & 9.1 & 14.8 & 5.4 & 10.4 & 15.5 & 8 & 11.4 & 8.3 & 5 & 6.2 \\
\hline Professionals & 17 & 11.4 & 15.1 & 14.8 & 15.4 & 15.1 & 16.2 & 17.1 & 16.7 & 15.9 & 14.3 & 14.9 \\
\hline Technicians ar & 6.3 & 2.7 & 5.1 & 10.4 & 8.1 & 9.3 & 13.3 & 8.6 & 10.7 & 4.4 & 5.6 & 5.2 \\
\hline Clerical suppo & 8.6 & 3.1 & 6.7 & 5.3 & 3.3 & 4.4 & 4.7 & 2.3 & 3.4 & 12.3 & 5.9 & 8.3 \\
\hline Service and sa & 9.5 & 14.1 & 11.1 & 10.1 & 15.1 & 12.4 & 7.1 & 13.4 & 10.5 & 14.4 & 20.1 & 18.1 \\
\hline Skilled agricul & 26.8 & 37.1 & 30.3 & 26.5 & 23.6 & 25.2 & 22.1 & 16.7 & 19.2 & 28.6 & 22.5 & 24.7 \\
\hline Craft and relat & 11.8 & 21.9 & 15.3 & 10.5 & 19 & 14.5 & 8.5 & 16.8 & 13 & 8.7 & 15.9 & 13.3 \\
\hline Plant and mac & 5.3 & 3.8 & 4.8 & 5.7 & 7.2 & 6.4 & 5.7 & 10.8 & 8.5 & 5.3 & 8.4 & 7.3 \\
\hline Elementary $\propto c$ & 2.4 & 3 & 2.6 & 1.9 & 2.8 & 2.3 & 7 & 6.3 & 6.6 & 2 & 2.1 & 2.1 \\
\hline & & & & & & & & & & & & \\
\hline \multicolumn{13}{|c|}{ Usual Job Economic Activity (1-digit, 1986-CODE INDEX, used in $88 / 98$ ) } \\
\hline Agri & 27.8 & 37.3 & 31.1 & 27.6 & 24.3 & 26.1 & 22.2 & 17.1 & 19.5 & & & \\
\hline Mining & 0.4 & 0.2 & 0.3 & 0.3 & 0.4 & 0.3 & 0.1 & 0.2 & 0.2 & & & \\
\hline Manufact & 12.5 & 15.2 & 13.4 & 11.3 & 14.7 & 12.9 & 9.4 & 13.8 & 11.8 & & & \\
\hline Elect & 1.3 & 0.3 & 1 & 1.6 & 0.6 & 1.2 & 2.2 & 1.1 & 1.6 & & & \\
\hline Const & 4.5 & 8.5 & 5.9 & 3.8 & 8.5 & 6 & 4.4 & 9.5 & 7.2 & & & \\
\hline Trade & 11.3 & 15.4 & 12.7 & 12.3 & 17.5 & 14.7 & 12.8 & 16.6 & 14.9 & & & \\
\hline Trans & 6.3 & 4 & 5.5 & 5.6 & 7 & 6.2 & 4.8 & 7.7 & 6.4 & & & \\
\hline Finance & 2.5 & 1.3 & 2.1 & 1.4 & 1 & 1.2 & 1.4 & 1.1 & 1.2 & & & \\
\hline Serv & 33.3 & 17.8 & 28 & 36.1 & 26 & 31.4 & 42.9 & 32.8 & 37.4 & & & \\
\hline & & & & & & & & & & & & \\
\hline \multicolumn{13}{|c|}{ region_HIECS_98 } \\
\hline Metropolitan & 33.8 & 29.9 & 31.9 & 30.8 & 27.2 & 29.1 & 26.7 & 21.4 & 24.1 & 10.9 & 8.3 & 9.5 \\
\hline Urban Lower & 16.7 & 15.7 & 16.2 & 16.9 & 15.1 & 16 & 16.1 & 14.2 & 15.2 & 15.7 & 14.1 & 14.8 \\
\hline Rural Lower & 18.8 & 21.3 & 20 & 19.2 & 22.5 & 20.8 & 21.2 & 25.9 & 23.5 & 20.6 & 19.9 & 20.2 \\
\hline Urban Upper & 17.3 & 17.2 & 17.3 & 18.7 & 18.6 & 18.7 & 19.4 & 19.5 & 19.4 & 23.1 & 27.7 & 25.7 \\
\hline Rural Lower & 13.4 & 15.9 & 14.6 & 14.4 & 16.7 & 15.5 & 16.6 & 19 & 17.8 & 18.4 & 20.7 & 19.7 \\
\hline Total & 100 & 100 & 100 & 100 & 100 & 100 & 100 & 100 & 100 & 100 & 100 & 100 \\
\hline & & & & & & & & & & & & \\
\hline $\begin{array}{l}\text { Vulnerable } \\
\text { Employment } \\
\text { (current) }\end{array}$ & 15.3 & 17.7 & 16.5 & 13.9 & 27.3 & 20.3 & 13.9 & 28 & 21 & 14.2 & 28.4 & 22.1 \\
\hline
\end{tabular}

Source: authors' calculations based on ELMPS 1998, 2006, 2012, 2018 (OAMDI 2019). 
Table A1b: Summary statistics of 2006 Egyptian youth in 2006, 2012, and 2018

\begin{tabular}{|c|c|c|c|c|c|c|c|c|c|}
\hline \multirow{3}{*}{$\begin{array}{l}\text { Age Grp in } \\
2006\end{array}$} & \multicolumn{3}{|c|}{2006} & \multicolumn{3}{|c|}{2012} & \multicolumn{2}{|c|}{\begin{tabular}{|l|l|}
2018 \\
\end{tabular}} & \multirow[b]{3}{*}{ Total } \\
\hline & Age 30 to & Youth: 15 & & Age 30 to & Youth: 15 & & Age 30 to & Youth: 15 & \\
\hline & 59 & to 29 & Total & & to 29 & Total & 59 & to 29 & \\
\hline & $\%$ & $\%$ & $\%$ & $\%$ & $\%$ & $\%$ & $\%$ & $\%$ & $\%$ \\
\hline \multicolumn{10}{|c|}{ Educational Attainment (7 Categories, age $6+$ ) } \\
\hline Illiterate & 35.4 & 13.8 & 24.3 & 39.4 & 14.7 & 26.7 & 37.3 & 18 & 26.9 \\
\hline Reads\&Write & 7.2 & 3.1 & 5.1 & 5.2 & 3 & 4.1 & 7.4 & 6.3 & 6.8 \\
\hline Less than Inte & 14.1 & 30.2 & 22.4 & 15 & 14.4 & 14.7 & 13 & 10.9 & 11.8 \\
\hline Intermediate & 24.2 & 38.6 & 31.6 & 23.7 & 43.6 & 33.9 & 26.1 & 41.2 & 34.2 \\
\hline Above Interm & 4.3 & 2.9 & 3.6 & 3.6 & 3.9 & 3.8 & 3.4 & 3.1 & 3.2 \\
\hline University & 14.2 & 11.3 & 12.7 & 12.3 & 19.6 & 16 & 11.9 & 19.5 & 16 \\
\hline post-graduate & 0.6 & 0.1 & 0.4 & 0.8 & 0.8 & 0.8 & 0.9 & 1.1 & 1 \\
\hline & & & & & & & & & \\
\hline \multicolumn{10}{|c|}{ Work status during ref. 3-month, market def. (search is not required) } \\
\hline Employed & 63.8 & 35.8 & 49.3 & 56.8 & 51.4 & 54 & 53.7 & 57.8 & 56 \\
\hline Unemployed & 1.6 & 8.4 & 5.1 & 1.4 & 9.1 & 5.4 & 1.7 & 6.8 & 4.5 \\
\hline Out of Labor I & 34.6 & 55.8 & 45.6 & 41.8 & 39.5 & 40.6 & 44.6 & 35.4 & 39.6 \\
\hline & & & & & & & & & \\
\hline \multicolumn{10}{|c|}{ Employment status of prim. Job (ref. 3-month) } \\
\hline wage worker & 57.2 & 54.3 & 56.1 & 60.8 & 69.7 & 65.2 & 59 & 66.6 & 63.2 \\
\hline employer & 13.6 & 5.2 & 10.4 & 13.4 & 6.4 & 9.9 & 9.5 & 5.8 & 7.4 \\
\hline self employec & 9.8 & 5.9 & 8.3 & 11.7 & 7 & 9.4 & 12.2 & 9 & 10.4 \\
\hline unpaid family & 19.4 & 34.6 & 25.3 & 14.1 & 17 & 15.5 & 19.4 & 18.6 & 18.9 \\
\hline & & & & & & & & & \\
\hline \multicolumn{10}{|c|}{ Economic sector of prim. Job (ref. 3-month) } \\
\hline government & 31.2 & 9.3 & 22.7 & 35.5 & 16.2 & 26 & 32.6 & 17.3 & 24 \\
\hline public enterpi & 5.5 & 2.3 & 4.2 & 3.4 & 3.1 & 3.3 & 2 & 1.7 & 1.9 \\
\hline private & 62.1 & 87.1 & 71.8 & 59.9 & 78.8 & 69.2 & 64.9 & 79.7 & 73.2 \\
\hline jopint-venture & 0.9 & 1.1 & 1 & 0.8 & 1.6 & 1.2 & 0.4 & 1.1 & 0.8 \\
\hline foreign & 0 & 0.1 & 0 & 0 & 0.1 & 0 & 0 & 0.1 & 0.1 \\
\hline other & 0.3 & 0.1 & 0.2 & 0.4 & 0.3 & 0.3 & 0 & 0 & 0 \\
\hline & & & & & & & & & \\
\hline \multicolumn{10}{|c|}{ Occup. of prim. job (1-digit based on ISCO88, ref. 3-month) } \\
\hline Managers & 10.1 & 2.9 & 7.3 & 11.5 & 4.7 & 8.1 & 6.5 & 3.6 & 4.9 \\
\hline Professionals & 15 & 7.9 & 12.3 & 15.7 & 13.2 & 14.5 & 14.5 & 12.3 & 13.3 \\
\hline Technicians a & 10.1 & 5 & 8.1 & 11.5 & 6.7 & 9.1 & 4.4 & 4.6 & 4.5 \\
\hline Clerical suppc & 4.6 & 2.3 & 3.7 & 3.6 & 2.1 & 2.9 & 9 & 4.9 & 6.7 \\
\hline Service and si & 10.8 & 14.1 & 12.1 & 7.3 & 13.3 & 10.3 & 15.5 & 18.7 & 17.3 \\
\hline Skilled agricu & 29.3 & 37.7 & 32.6 & 26.4 & 24.3 & 25.3 & 32 & 27.7 & 29.6 \\
\hline Craft and rela & 12.1 & 20.5 & 15.4 & 10.2 & 19.6 & 14.8 & 10.1 & 16.6 & 13.7 \\
\hline Plant and ma & 6 & 6.3 & 6.1 & 7.2 & 10.3 & 8.8 & 5.6 & 8.6 & 7.3 \\
\hline Elementaryo & 2 & 3.3 & 2.5 & 6.6 & 5.7 & 6.1 & 2.3 & 3 & 2.7 \\
\hline
\end{tabular}

\begin{tabular}{|c|c|c|c|c|c|c|c|c|c|}
\hline \multicolumn{10}{|c|}{ Usual Job Economic Activity (1-digit, 1986-CODE INDEX, used in 88/98) } \\
\hline Agri & 30.3 & 38 & 33.3 & 26.5 & 24.6 & 25.6 & & & \\
\hline Mining & 0.2 & 0.3 & 0.2 & 0.1 & 0.2 & 0.2 & & & \\
\hline Manufact & 11.1 & 14.2 & 12.3 & 9.4 & 13.1 & 11.2 & & & \\
\hline Elect & 1.3 & 0.4 & 1 & 1.8 & 1.2 & 1.5 & & & \\
\hline Const & 5.5 & 9.1 & 6.9 & 5.9 & 12.4 & 9.1 & & & \\
\hline Trade & 11.4 & 14.9 & 12.8 & 12 & 15.6 & 13.8 & & & \\
\hline Trans & 6.4 & 6.1 & 6.3 & 5.8 & 6.9 & 6.4 & & & \\
\hline Finance & 1.3 & 0.3 & 1 & 1.2 & 0.6 & 0.9 & & & \\
\hline Serv & 32.4 & 16.7 & 26.3 & 37.1 & 25.4 & 31.3 & & & \\
\hline \multirow{2}{*}{\multicolumn{10}{|c|}{ region_HIECS_06 }} \\
\hline & & & & & & & & & \\
\hline Metropolitan & 28.2 & 24 & 26 & 23 & 19.5 & 21.2 & 11 & 7.2 & 9 \\
\hline Urban Lower & 13.5 & 13 & 13.3 & 13.2 & 12.3 & 12.7 & 12.8 & 12.2 & 12.4 \\
\hline Rural Lower & 24.6 & 25.9 & 25.2 & 27.6 & 28.3 & 27.9 & $16 . \overline{0}$ & 15.4 & 10 \\
\hline Urban Upper & 15.4 & 14.8 & 15.1 & 16 & 15.2 & 15.6 & 29.8 & 30.7 & 30.3 \\
\hline Rural Lower & 18.2 & 22.3 & 20.3 & 20.2 & 24.7 & 22.5 & 21.6 & 26.8 & 24.4 \\
\hline & & & & & & & & & \\
\hline \multicolumn{10}{|l|}{ Vulnerable } \\
\hline $\begin{array}{l}\text { Employment } \\
\text { (current) }\end{array}$ & 20.2 & 23.7 & 22 & 18.6 & 29.7 & 24.3 & 18.9 & 31.1 & 25.5 \\
\hline \multicolumn{10}{|l|}{ Vulnerable } \\
\hline $\begin{array}{l}\text { Employment } \\
\text { (usual) }\end{array}$ & 20.6 & 24.2 & 22.5 & 19 & 30.3 & 24.8 & & & \\
\hline
\end{tabular}

Source: authors' calculations based on ELMPS 2006, 2012, 2018 (OAMDI 2019). 
Table A1c: Summary statistics of 2012 Egyptian youth in 2012 and 2018

\begin{tabular}{|c|c|c|c|c|c|c|}
\hline \multirow[b]{2}{*}{$\begin{array}{l}\text { Age Grp in } \\
2012\end{array}$} & \multicolumn{3}{|c|}{2012} & \multicolumn{3}{|c|}{2018} \\
\hline & $\begin{array}{l}\text { Age } 30 \text { to } \\
59\end{array}$ & $\begin{array}{l}\text { Youth: } 15 \\
\text { to } 29\end{array}$ & Total & $\begin{array}{l}\text { Age } 30 \text { to } \\
59\end{array}$ & $\begin{array}{l}\text { Youth: } 15 \\
\text { to } 29\end{array}$ & Total \\
\hline & $\%$ & $\%$ & $\%$ & $\%$ & $\%$ & $\%$ \\
\hline
\end{tabular}

Educational Attainment ( 7 Categories, age $6+$ )

\begin{tabular}{|l|c|c|}
\hline IIliterate & 32 & 11.9 \\
\hline Reads\&Writes & 4.6 & 2.1 \\
\hline Less than Interr & 14.5 & 30.2 \\
\hline Intermediate & 29.3 & 40.2 \\
\hline Above Intermec & 3.6 & 2.4 \\
\hline University & 15.2 & 12.8 \\
\hline post-graduate & 0.9 & 0.5 \\
\hline
\end{tabular}

\begin{tabular}{|l|r|r|r|}
\hline 22 & 33.8 & 14.3 & 24.3 \\
\hline
\end{tabular}

\begin{tabular}{|l|r|r|r|}
\hline 22 & 33.8 & 14.3 & 24.3 \\
\hline 3.3 & 7.1 & 4.7 & 5.9 \\
\hline
\end{tabular}

\begin{tabular}{r|r|r|r|r|r|r|r|r|}
\hline 22.2 & 12 & 13 & 12.5 \\
\hline
\end{tabular}

\begin{tabular}{l|r|r|r|}
\hline 34.7 & 29.4 & 44.9 & 36.9
\end{tabular}

\begin{tabular}{l|r|r|r|r|r|r|r}
\hline 3 & 3.2 & 2.8 & 3 \\
\hline
\end{tabular}

\begin{tabular}{|r|r|r|r|}
\hline 14 & 13.7 & 19.5 & 16.5 \\
\hline
\end{tabular}

Work status during ref. 3 -month, market def. (search is

\begin{tabular}{|l|c|c|c|r|r|r|r|}
\hline Work status during ref. 3-month, market def. (search is & & \\
\hline Employed & 61 & 35.2 & 48.2 & 56.7 & 48.2 & 52.5 \\
\hline Unemployed & 3 & 7.1 & 5 & 2.8 & 8.4 & 5.5 \\
\hline Out of Labor Fo & 36 & 57.7 & 46.7 & 40.5 & 43.4 & 42 \\
\hline
\end{tabular}

Employment status of prim. Job (ref. 3-month)

\begin{tabular}{l|l|l|l|}
\hline & 11.3 & 3.9 & 8.5 \\
\hline
\end{tabular}

\begin{tabular}{|l|l|r|r|r|}
\hline 5.8 & 8.3 & 11.1 & 7.9 & 9.7 \\
\hline
\end{tabular}

\begin{tabular}{|l|l|l|r|r|r|r|}
\hline unpaid family $\mathrm{n}$ & 14 & 24.8 & 18 & 20 & 22 & 20.9 \\
\hline
\end{tabular}

Economic sector of prim. Job (ref. 3-month)

government

public enterpris

private

30.7

\begin{tabular}{|l|l|l|l|}
\hline jopint-venture & 1.2 & 1.3 & 1.2 \\
\hline
\end{tabular}

\begin{tabular}{l|l} 
foreign & 0.1
\end{tabular}

\begin{tabular}{l|l|l|l|}
\hline 0.1 & 0.1 & 0.1 \\
\hline 0.3
\end{tabular}

other

0.3

0.2

0.3

Occup. of prim. job (1-digit based on ISCO88, ref. 3-mot

\begin{tabular}{|l|c|c|c|r|r|r|r|}
\hline Managers & 9.1 & 2.9 & 6.8 & 5.7 & 2.7 & 4.4 \\
\hline Professionals & 15.5 & 10.4 & 13.6 & 13.5 & 10.3 & 12 \\
\hline Technicians anc & 10.5 & 4.9 & 8.4 & 4.6 & 4.1 & 4.4 \\
\hline Clerical support & 3 & 1.6 & 2.5 & 7.2 & 3.7 & 5.6 \\
\hline Service and sale & 8.9 & 12.4 & 10.2 & 16 & 17.3 & 16.6 \\
\hline Skilled agriculti & 25.1 & 33 & 28.1 & 32.6 & 32.3 & 32.5 \\
\hline Craft and relate & 13 & 20.5 & 15.8 & 11.8 & 18.2 & 14.7 \\
\hline Plant and mach & $\mathbf{8 . 2}$ & 9.6 & 8.7 & 6.3 & 8.1 & 7.1 \\
\hline Elementary occ & 6.5 & 4.8 & 5.9 & 2.4 & 3.3 & 2.8 \\
\hline
\end{tabular}

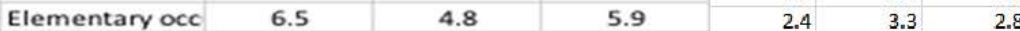

Usual Job Economic Activity (1-digit, 1986-CODE INDEX,

\begin{tabular}{l|l|l|l}
\hline Agri & 25.4 & 33.2 & 28.3
\end{tabular}

\begin{tabular}{l|c|c|c|}
\hline Mining & 0.2 & 0.2 & 0.2
\end{tabular}

\begin{tabular}{l|c|c|c|}
\hline Mining & 0.2 & 0.2 & 0.2 \\
\hline Manufact & 10.7 & 11.4 & 11
\end{tabular}

\begin{tabular}{l|l|l|l|} 
Elect & 1.8 & 1 & 1.5 \\
\hline
\end{tabular}

\begin{tabular}{l|l|l|l|}
\hline Const & 8.1 & 13.9 & 10.2 \\
\hline
\end{tabular}

\begin{tabular}{l|l|l|l}
\hline Trade & 12.3 & 13.5 & 12.7 \\
\hline
\end{tabular}

\begin{tabular}{|l|l|l|l|}
\hline Trans & 6.3 & 6.8 & 6.5 \\
\hline
\end{tabular}

\begin{tabular}{l|l|l|l} 
Finance & 1.1 & 0.5 & 0.8 \\
\hline
\end{tabular}

\begin{tabular}{|l|l|l|l|}
\hline Serv & 34.2 & 19.6 & 28.7 \\
\hline
\end{tabular}

region_HIECS_12

\begin{tabular}{|l|l|l|l|r|r|r|}
\hline Metropolitan Ci & 22.1 & 17.4 & 19.8 & 10.2 & 6.9 & 8.6 \\
\hline
\end{tabular}

\begin{tabular}{|l|r|r|r|r|r|r|}
\hline Urban Lower & 11.9 & 10.5 & 11.2 & 12 & 10.5 & 11.3 \\
\hline
\end{tabular}

\begin{tabular}{|l|l|l|l|l|r|r|}
\hline Rural Lower & 28.1 & 27.9 & 28 & 14.3 & 14.2 & 14.3 \\
\hline
\end{tabular}

\begin{tabular}{|l|l|l|l|l|l|l|}
\hline Urban Upper & 14.2 & 14 & 14.1 & 30.5 & 30.2 & 30.3 \\
\hline
\end{tabular}

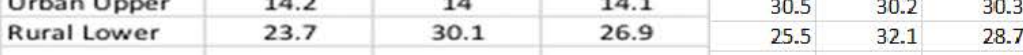

\begin{tabular}{|l|l|l|l|l|l|l|l|l|l|}
\hline Vulnerable & & & \\
Employment & & &
\end{tabular}

Vulnerable

Employment

(usual)

24.3

24.4

24.3

Source: authors' calculations based on ELMPS 2012, 2018 (OAMDI 2019). 
Table A1d: Summary statistics of 2010 Jordanian youth in 2010 and 2016

\begin{tabular}{|c|c|c|c|c|c|c|c|}
\hline \multirow{3}{*}{$\begin{array}{l}\text { Age Grp in } \\
2010\end{array}$} & \multicolumn{3}{|c|}{2010} & \multicolumn{4}{|c|}{2016} \\
\hline & \multirow[b]{2}{*}{ Age 30 to 5 : } & \multirow[b]{2}{*}{9 Youth: 15 to } & \multirow[b]{2}{*}{ Total } & \multirow[b]{2}{*}{ Age 30 to 5} & \multirow[b]{2}{*}{9 Youth: 15 to } & \multirow{2}{*}{\multicolumn{2}{|c|}{ Total }} \\
\hline & & & & & & & \\
\hline & $\%$ & $\%$ & $\%$ & $\%$ & $\%$ & $\%$ & \\
\hline \multicolumn{8}{|c|}{ Education Levels (1-digit) } \\
\hline Illiterate & 7.9 & 2.5 & 5.8 & 10.8 & 6 & 9. & 9.1 \\
\hline Read \& Write & 19.2 & 11.5 & 16.3 & 22.2 & 14.9 & 19. & 9.6 \\
\hline Basic Educatic & 30.2 & 43.6 & 35.3 & 29.9 & 36.6 & 32. & 2.3 \\
\hline Secondary Edu & 16.9 & 15.4 & 16.3 & 14.7 & 17.3 & 15. & 5.7 \\
\hline Post-Seconda & 13.1 & 7.8 & 11.1 & 11.4 & 8 & 10. & 0.2 \\
\hline University & 10.6 & 18.2 & 13.5 & 9.2 & 15.3 & 11. & 1.4 \\
\hline Post-Graduate & 2.1 & 1 & 1.7 & 1.8 & 1.8 & & 1.8 \\
\hline Work status $d u$ & uring ref. $3 \cdot \mathrm{m}$ & onth, market & def. (search is & is not requirec & & & \\
\hline Employed & 48.7 & 47.7 & 48.4 & 34.9 & 50.3 & 40. & 0.4 \\
\hline Unemployed & 3.3 & 13.6 & 7.2 & 4.4 & 11.2 & & 6.9 \\
\hline Out of Labor F & 48 & 38.7 & 44.4 & 60.7 & 38.4 & 52. & 2.7 \\
\hline & & & & & & & \\
\hline employment st & status in prim & job (ref. $3 \mathrm{mo}$ & onths) & & & & \\
\hline Waged emplo & 78.6 & 93.3 & 84.2 & 75.2 & 89.2 & 81. & 1.3 \\
\hline Employer & 7.5 & 1.7 & 5.3 & 6.3 & 2.5 & & 4.6 \\
\hline Self-employed & 13.3 & 3.6 & 9.7 & 13.4 & 6.8 & 10. & 0.5 \\
\hline Unpaid family & 0.5 & 1.4 & 0.9 & 5 & 1.5 & & 3.5 \\
\hline & & & & & & & \\
\hline Economic sect & tor of prim. jo & $b$ (ref. 3-mnth & & & & & \\
\hline government & 42.5 & 47.8 & 44.5 & 44.3 & 57.4 & & 50 \\
\hline public & 2.4 & 0.7 & 1.8 & 0.8 & 0.8 & & 0.8 \\
\hline private & 54 & 51.1 & 52.9 & 53.4 & 40.4 & 47. & 7.7 \\
\hline Other & 0 & 0 & 0 & 0.6 & 0.5 & & 0.5 \\
\hline international & 1.1 & 0.3 & 0.8 & 0.9 & 0.8 & & 0.9 \\
\hline Occup. of prim & n. job (1-digit & based on ISCC & 02008 , ref. $3-1$ & mnths) & & & \\
\hline Managers & 2.1 & 0.2 & 1.4 & 1.3 & 0.3 & & 0.9 \\
\hline Professionals & 18.7 & 18.1 & 18.5 & 19.2 & 19.2 & 19. & 9.2 \\
\hline Technicians ar & 7.9 & 5.8 & 7.1 & 7 & 6.6 & & 6.9 \\
\hline Clerical suppoI & 10.5 & 7.3 & 9.3 & 8.8 & 6.5 & & 7.8 \\
\hline Service and sa & 24.2 & 36.9 & 29 & 22.3 & 33.2 & 27. & 7.1 \\
\hline Skilled agricult & 2.8 & 1.5 & 2.3 & 7.9 & 3 & & 5.8 \\
\hline Craft and relat & 13 & 16 & 14.2 & 13.3 & 12 & 12. & 2.7 \\
\hline Plant and mac & 14 & 6.7 & 11.3 & 13.2 & 11.9 & 12. & 2.6 \\
\hline Elementary oc & 6.7 & 7.3 & 7 & 7 & 7.2 & & 7.1 \\
\hline & & & & & & & \\
\hline Economic activ & vity of prim. jo & ob (Sections (1) & 1 digit), based & on ISICA, ref. & 3-mnths) & & \\
\hline A:Agriculture, & 3.5 & 1.8 & 2.9 & 8.2 & 3.1 & & 5.9 \\
\hline B:Mining and & 1.4 & 0.4 & 1 & 1.7 & 0.6 & & 1.2 \\
\hline C:Manufacturi & 10.1 & 11.5 & 10.6 & 8.2 & 9.6 & & 8.8 \\
\hline D:Electricity,ga & 0.8 & 0.6 & 0.7 & 0.7 & 0.4 & & 0.6 \\
\hline E:Water suppl & 0.4 & 0.3 & 0.3 & 0.3 & 0.1 & & 0.2 \\
\hline $\mathrm{F}$ :Construction & 4.9 & 5.3 & 5 & 5.6 & 3.4 & & 4.7 \\
\hline G:Wholesale a & 12.5 & 13.3 & 12.8 & 15.1 & 10.3 & & 13 \\
\hline $\mathrm{H}$ :Transportati & 10.1 & 4.1 & 7.9 & 8.1 & 5.4 & & 6.9 \\
\hline 1:Accomodatio & 1.8 & 2.4 & 2 & 0.9 & 2.4 & & 1.5 \\
\hline J:Information : & 0.9 & 1.3 & 1.1 & 0.5 & 0.2 & & 0.4 \\
\hline K:Financial an & 1.2 & 1.4 & 1.3 & 1.3 & 0.9 & & 1.1 \\
\hline L:Real estate : & 0.6 & 0.1 & 0.4 & 0.2 & 0.1 & & 0.1 \\
\hline M:Professiona & 1.5 & 1.5 & 1.5 & 1.9 & 1.5 & & 1.7 \\
\hline N:Administrat & 1.1 & 0.8 & 1 & 2.2 & 0.8 & & 1.6 \\
\hline $\mathrm{O}$ :Public admit & 25.1 & 36.4 & 29.3 & 21.2 & 41.5 & 30. & 0.1 \\
\hline P:Education & 16 & 10.9 & 14.1 & 16.4 & 11.8 & 14. & 4.4 \\
\hline Q:Human heal & 4.7 & 4.3 & 4.6 & 4.6 & 5.3 & & 4.9 \\
\hline R:Arts, enterta & 0.5 & 0.2 & 0.4 & 0.6 & 0.6 & & 0.6 \\
\hline S:other service & 2.4 & 2.7 & 2.5 & 1.5 & 1.7 & & 1.6 \\
\hline T:Activities of & 0.2 & 0.1 & 0.2 & 0.1 & 0 & & 0 \\
\hline U:Activities of & 0.3 & 0.1 & 0.2 & 0.7 & 0.3 & & 0.5 \\
\hline & & & & & & & \\
\hline region & & & & & & & \\
\hline middle & 51 & 48 & 49.8 & 48.3 & 43.8 & 46. & 5.7 \\
\hline north & 33.5 & 35 & 34.1 & 33.9 & 36.1 & 34. & 4.7 \\
\hline south & 15.5 & 17 & 16.1 & 17.8 & 20.1 & & 8.6 \\
\hline Vulnerable & & & & & & & \\
\hline $\begin{array}{l}\text { Employment } \\
\text { (current) }\end{array}$ & 12.6 & 12.7 & 12.6 & 8.5 & 9.5 & & 8.9 \\
\hline Vulnerable & & & & & & & \\
\hline $\begin{array}{l}\text { Employment } \\
\text { (usual) }\end{array}$ & 13.1 & 13.2 & 13.2 & 9.5 & 10.8 & & 9.9 \\
\hline
\end{tabular}

Source: authors' calculations based on JLMPS 2010, 2016 (OAMDI 2019). 
Table A1e: Summary statistics of 2016 Jordanian youth

\begin{tabular}{|c|c|c|c|}
\hline \multirow{3}{*}{$\begin{array}{l}\text { Age Grp in } \\
2016\end{array}$} & \multicolumn{3}{|c|}{2016} \\
\hline & & \multirow{2}{*}{9 Youth: 15 to } & \\
\hline & Age 30 to 59 & & $\begin{array}{l}\text { Total } \\
\%\end{array}$ \\
\hline \multicolumn{4}{|c|}{ Education Levels (1-digit) } \\
\hline Illiterate & 8.7 & 5.4 & 7.4 \\
\hline Read \& Write & 18.4 & 13.4 & 16.4 \\
\hline Basic Educatio & 30 & 40.5 & 34.2 \\
\hline Secondary Edu & 15.2 & 13 & 14.3 \\
\hline Post-Secondar & 11.1 & 6.2 & 9.1 \\
\hline University & 14.2 & 21 & 16.9 \\
\hline Post-Graduate & 2.3 & 0.6 & 1.6 \\
\hline \multicolumn{4}{|c|}{ Work status during ref. 3-month, market def. (search i: } \\
\hline Employed & 43 & 37.1 & 40.6 \\
\hline Unemployed & 4.9 & 18.4 & 10.3 \\
\hline Out of Labor $\mathrm{Fa}$ & 52.1 & 44.5 & 49.1 \\
\hline \multicolumn{4}{|c|}{ employment status in prim job (ref. 3 months) } \\
\hline Waged emplo & 81.4 & 92.3 & 85.3 \\
\hline Employer & 5.3 & 1.3 & 3.8 \\
\hline Self-employed & 10.4 & 4.9 & 8.4 \\
\hline Unpaid family & 3 & 1.6 & 2.5 \\
\hline \multicolumn{4}{|c|}{ Economic sector of prim. job (ref. 3-mnths) } \\
\hline government & 49.3 & 50.4 & 49.7 \\
\hline public & 0.7 & 0.9 & 0.8 \\
\hline private & 48.8 & 47.4 & 48.3 \\
\hline Other & 0.4 & 0.4 & 0.4 \\
\hline international & 0.8 & 0.9 & 0.9 \\
\hline \multicolumn{4}{|c|}{ Occup. of prim. job (1-digit based on ISCO 2008, ref. 3 - } \\
\hline Managers & 1 & 0.1 & 0.6 \\
\hline Professionals & 23.9 & 20.1 & 22.5 \\
\hline Technicians an & 7.5 & 5.4 & 6.8 \\
\hline Clerical suppor & 8 & 3.8 & 6.5 \\
\hline Service and sal & 23.5 & 39 & 29.1 \\
\hline Skilled agricult & 5.5 & 2.7 & 4.5 \\
\hline Craft and relat & 12.7 & 13.7 & 13 \\
\hline Plant and macl & 11.4 & 7.8 & 10.1 \\
\hline Elementary oci & 6.6 & 7.4 & 6.9 \\
\hline \multicolumn{4}{|c|}{ Economic activity of prim. job (Sections(1digit), based } \\
\hline A:Agriculture, 1 & 5.7 & 3.1 & 4.8 \\
\hline B:Mining and $c$ & 1.4 & 0.8 & 1.2 \\
\hline C:Manufacturir & 8.4 & 10.4 & 9.1 \\
\hline D:Electricity,ga & 0.6 & 0.3 & 0.5 \\
\hline E:Water supply & 0.4 & 0.2 & 0.3 \\
\hline F:Construction & 5.1 & 5 & 5 \\
\hline G:Wholesale a & 12.6 & 12.8 & 12.7 \\
\hline H:Transportatis & 6.7 & 3.1 & 5.4 \\
\hline I:Accomodatio I & 1.4 & 2.9 & 1.9 \\
\hline J:Information a & 0.6 & 0.8 & 0.7 \\
\hline K:Financial anc & 1.4 & 1.3 & 1.4 \\
\hline L:Real estate a & 0.3 & 0 & 0.2 \\
\hline M:Professional & 1.9 & 2.3 & 2.1 \\
\hline $\mathrm{N}$ :Administrati & 1.6 & 1.1 & 1.4 \\
\hline O:Public admir & 27.8 & 39.4 & 32 \\
\hline P:Education & 15.3 & 8.2 & 12.7 \\
\hline Q:Human healt & 5.3 & 5.4 & 5.4 \\
\hline R:Arts, enterta & 0.6 & 0.3 & 0.5 \\
\hline S:other service & 2 & 2.1 & 2 \\
\hline $\mathrm{T}$ :Activities of $\mathrm{I}$ & 0.2 & 0.2 & 0.2 \\
\hline U:Activities of & 0.7 & 0.4 & 0.6 \\
\hline \multicolumn{4}{|l|}{ Region } \\
\hline Middle & 49 & 47.6 & 48.4 \\
\hline North & 33.9 & 33.5 & 33.8 \\
\hline South & 17 & 19 & 17.8 \\
\hline Vulnerable & & & \\
\hline $\begin{array}{l}\text { Employment } \\
\text { (current) }\end{array}$ & 9 & 8.1 & 8.6 \\
\hline $\begin{array}{l}\text { Vulnerable } \\
\text { Employment } \\
\text { (usual) }\end{array}$ & 10.2 & 9 & 9.7 \\
\hline
\end{tabular}

Source: authors' calculations based on JLMPS 2016 (OAMDI 2019). 
Table A1f: Summary statistics of 2014 Tunisian youth

\begin{tabular}{|l|r|r|r|}
\hline & \multicolumn{3}{c|}{2014} \\
\hline Age Grp in 2008 & Age 30 to 59 & Youth: 15 to 29 & Total \\
\hline & $\%$ & $\%$ & $\%$ \\
\hline Educational attainment (6 categories age 6+) & & & \\
\hline Illiterate & 41.6 & 12.9 & 31.8 \\
\hline Read and write & 20.7 & 13.3 & 18.2 \\
\hline Less than Int. & 25 & 42.9 & 31.1 \\
\hline Intermediate & 8 & 14.4 & 10.2 \\
\hline Above Intermediate & 1.8 & 7.9 & 3.8 \\
\hline University \& Above & 2.9 & 8.6 & 4.8 \\
\hline
\end{tabular}

Work status during ref. 3 -month, market def. (search is not required)

$\begin{array}{lll}\text { Employed } & 48.3 & 46.9\end{array}$

$\begin{array}{llll}\text { Unemployed } & 2 & 14.8 & 6.5\end{array}$

\begin{tabular}{|l|r|r|r|}
\hline Out of Labor Force & 49.8 & 38.3 & 45.7 \\
\hline
\end{tabular}

Employment status in prim job (ref. 3 months)

Waged employee

Employer

Self-employed

Unpaid family worker

\begin{tabular}{r|r|r|}
\hline 57.2 & 69.9 & 61.5 \\
\hline
\end{tabular}

$\begin{array}{lrr}5.4 & 2.9 & 4.6\end{array}$

\begin{tabular}{r|r|r}
5.4 & 11.7 & 17.4 \\
\hline
\end{tabular}

(1)

Economic sector of prim. job (ref. 3-mnths)

government

public enterprise 15.7

$75.6-77.2-76.1$

\begin{tabular}{l|l|l|l|} 
foreign & 1.3 & 3.9 & 2.1
\end{tabular}

\begin{tabular}{|l|r|r|r|}
\hline NGO & 0 & 0.2 & 0.1 \\
\hline
\end{tabular}

\begin{tabular}{|l|l|l|l|}
\hline Other & 1.7 & 1.1 & 1.5 \\
\hline
\end{tabular}

Occup. of prim. job (1-digit ref. 3-mnths)

Managers

Professionals

Technicians and associate professir

Clerical support workers

Service and sales workers

Skilled agricultural, forestry and fis

Craft and related trades work

Plant and machine operators, and $\hat{\mathrm{c}}$

Elementary occupations $\quad 18$

\begin{tabular}{l|l|}
\hline 0.8 & 1.6 \\
\hline
\end{tabular}

\begin{tabular}{r|r|r|}
\hline 2 & 0.8 & 1.6 \\
\hline 6.3 & 6.6 & 6.4 \\
\hline
\end{tabular}

$2.8-4.5-3.4$

\begin{tabular}{r|r|r|r|}
2.6 & 4.3 & 3.2
\end{tabular}

\begin{tabular}{|r|r|r}
\hline 17.8 & 15.2 \\
\hline
\end{tabular}

$28 \quad 17.3 \quad 24.5$

\begin{tabular}{rr}
21.8 & 20.5 \\
\hline & -3.3
\end{tabular}

\begin{tabular}{r|r|r|r|r|}
\hline 18.5 & 18.5 \\
\hline
\end{tabular}

Economic activity of prim. job (Sections (1digit) ref. 3-mnths)

\begin{tabular}{|l|l|l|l|}
\hline A:Agriculture, forestry and fishing & 40.7 & 29.4 & 37 \\
\hline
\end{tabular}

\begin{tabular}{|l|r|r|}
\hline B:Mining and quarrying & 1 & 1.2
\end{tabular}

$\begin{array}{lrrr}\text { C:Manufacturing } & 8.5 & 16.6 & 11.1\end{array}$

D:Electricity,gas,steam and air conc $\quad 00.1 \quad 0.1$

\begin{tabular}{rr|r|r|r}
\hline E:Water supply;sewage, waste man & 0.2 & 0 & 0.1
\end{tabular}

\begin{tabular}{|l|r|r|r|}
\hline F:Construction & 16.4 & 16.3 & 16.4 \\
\hline
\end{tabular}

$\begin{array}{llll}\text { G:Wholesale and retail trade; repa } & 7.9 & 9.6 & 8.5\end{array}$

\begin{tabular}{|l|l|l|l|}
\hline $\mathrm{H}:$ Transportation and storage & 3.5 & 4.1 & 3.7 \\
\hline
\end{tabular}

\begin{tabular}{|l|l|l|l|}
\hline I:Accomodation and food service a & 2.3 & 3.3 & 2.7 \\
\hline
\end{tabular}

\begin{tabular}{ll|l|l|l|}
\hline J:Information and communication & 0.5 & 0.5 & 0.5 \\
\hline
\end{tabular}

K:Financial and insurance activities $\quad 0.6 \quad 0.3 \quad 0.5$

\begin{tabular}{|l|l|l|l|}
\hline L:Real estate activities & 0.1 & 0 & 0.1
\end{tabular}

\begin{tabular}{rr|r|r|}
\hline M:Professional, scientific and tech & 0 & 0.2 & 0.1
\end{tabular}

$\begin{array}{llll}\mathrm{N} \text { :Administrative and support serv } & 0.3 & 0.4 & 0.4\end{array}$

$\begin{array}{llll}\mathrm{O}: \text { Public administration and defen } & 8 & 6.2 & 7.5\end{array}$

\begin{tabular}{|l|l|l|l|}
\hline P:Education & 6.7 & 5.3 & 6.3 \\
\hline
\end{tabular}

\begin{tabular}{llll|l|l|}
\hline Q:Human health and social work ac & 1.3 & 2.9 & 1.8 \\
\hline
\end{tabular}

$\begin{array}{lrrr}\text { R:Arts, entertainment and recreati } & 0.2 & 0.9 & 0.4\end{array}$

\begin{tabular}{l|l|l|l|}
\hline S:other service activities & 1 & 2.6 & 1.5 \\
\hline
\end{tabular}

\begin{tabular}{lllll}
\hline T:Activities of households as empli & 0.6 & 0.1 & 0.4
\end{tabular}

\begin{tabular}{|l|l|l|l|}
\hline Region (six regions) & \\
\hline
\end{tabular}

\begin{tabular}{|l|l|l|l|}
\hline North & 32.6 & 31.9 & 32.3 \\
\hline
\end{tabular}

\begin{tabular}{|l|l|l|l|}
\hline North West & 15.5 & 11.8 & 14.2 \\
\hline
\end{tabular}

\begin{tabular}{|l|r|r|r|}
\hline Center East & 22.4 & 23.4 & 22.8 \\
\hline
\end{tabular}

\begin{tabular}{|l|r|r|r|}
\hline Center West & 15 & 15.6 & 15.3 \\
\hline
\end{tabular}

$\begin{array}{rrr}9.2 & 11.5 & 10\end{array}$

\begin{tabular}{|l|r|r|r|}
\hline South West & 5.2 & 5.7 & 5.4 \\
\hline
\end{tabular}

\begin{tabular}{|l|r|r|r|}
\hline Vulnerable Employment (current) & 18.5 & 16.9 & 17.9 \\
\hline Vulnerable Employment (usual) & 19.6 & 18.3 & 19.2 \\
\hline
\end{tabular}

Source: authors' calculations based on TLMPS 2014 (OAMDI 2019). 
Table A2a: Monetary vulnerability benchmarks for Egypt, 2018 prices

\begin{tabular}{lcccccc}
\hline & PL (annual) & PL (monthly) & LEL 1998 & LEL 2006 & LEL 2012 & LEL 2018 \\
Metropolitan cities & 9280.1 & 773.3 & 2857.1 & 2676.5 & 2757.6 & 2873.3 \\
Urban lower & 8536.9 & 711.4 & 2837.0 & 2514.2 & 2595.8 & 2654.4 \\
Rural lower & 8673.0 & 722.8 & 3040.0 & 2666.1 & 2748.0 & 2819.8 \\
Urban upper & 8728.5 & 727.4 & 3158.1 & 2734.9 & 2693.9 & 2749.2 \\
Rural lower & 8865.6 & 738.8 & 3794.5 & 2759.5 & 3139.4 & 3135.3 \\
Total & 8876.4 & 739.7 & 3133.2 & 2687.7 & 2825.7 & 2899.9 \\
\hline
\end{tabular}

Note: all values are in 2018 prices. Real wage values available in the surveys were used to determine earnings status. LELs vary by year due to differences in dependency ratios over time.

Source: authors' calculations based on poverty lines from CAPMAS (2018).

Table A2b: Monetary vulnerability benchmarks for Jordan

\begin{tabular}{lcccc} 
Region & PL (annual, 2010 prices) & PL (monthly, 2010 prices) & LEL (2010 prices) & LEL (2016 prices) \\
Middle & 814 & 67.8 & 323.1 & 375.5 \\
North & 814 & 67.8 & 337.3 & 376.4 \\
South & 814 & 67.8 & 327.9 & 376.7 \\
Total & 814 & 67.8 & 328.6 & 376.0 \\
\hline
\end{tabular}

Note: the poverty line for 2010 was inflated using the CPI to 2016 prices and used to calculate the LEL for 2016 along with the year-specific and region-specific dependency ratios. Nominal wage values were then used to determine earnings status.

Source: authors' calculations based on poverty lines from DOS (2010).

Table A2c: Monetary vulnerability benchmarks for Tunisia

\begin{tabular}{lccc}
\hline Region & PL (annual) & PL (monthly) & LEL \\
Greater Tunis & 1706 & 142.2 & 518.8 \\
North East & 1706 & 142.2 & 508.7 \\
North West & 1706 & 142.2 & 504.6 \\
Centre East & 1706 & 142.2 & 513.3 \\
Centre West & 1706 & 142.2 & 617.2 \\
South East & 1706 & 142.2 & 571.2 \\
South West & 1706 & 142.2 & 476.5 \\
Total & 1706 & 142.2 & 530.8 \\
\hline
\end{tabular}

Note: the LELs reflect region-specific dependency ratios.

Source: authors' calculations based on poverty lines from World Bank (2016). 
Table A3: Multinomial logit of employment type: pooled Egyptian and Jordanian surveys, youth and non-youth jointly

\begin{tabular}{|c|c|c|c|c|c|c|c|c|c|c|}
\hline & \multicolumn{5}{|c|}{ Egypt 2006, 2012 \& 2018} & \multicolumn{5}{|c|}{ Jordan 2016} \\
\hline & $\begin{array}{c}\text { Self- } \\
\text { empl./Unpaid } \\
\text { family wrkr. }\end{array}$ & $\begin{array}{l}\text { Informal+ } \\
\text { irregular }\end{array}$ & $\begin{array}{l}\text { Public + } \\
\text { formal } \\
\text { private }\end{array}$ & Employer & Unemployed & $\begin{array}{c}\text { Self- } \\
\text { empl./Unpaid } \\
\text { family wrkr. }\end{array}$ & $\begin{array}{c}\text { Informal+ } \\
\text { irregular }\end{array}$ & $\begin{array}{l}\text { Public + } \\
\text { formal } \\
\text { private }\end{array}$ & Employer & Unemployed \\
\hline Youth $=1$ & $\begin{array}{c}0.252^{* * *} \\
(0.087)\end{array}$ & $\begin{array}{c}0.467^{* * *} \\
(0.085)\end{array}$ & $\begin{array}{l}0.186^{* *} \\
(0.082)\end{array}$ & $\begin{array}{c}0.557^{* * *} \\
(0.120)\end{array}$ & $\begin{array}{c}0.113 \\
(0.103)\end{array}$ & $\begin{array}{l}0.685^{* *} \\
(0.348)\end{array}$ & $\begin{array}{c}0.921^{* * *} \\
(0.277)\end{array}$ & $\begin{array}{l}0.291^{*} \\
(0.173)\end{array}$ & $\begin{array}{c}1.216^{* * *} \\
(0.472)\end{array}$ & $\begin{array}{c}0.386 \\
(0.236)\end{array}$ \\
\hline Age - min(age) & $\begin{array}{c}0.242^{* * *} \\
(0.013)\end{array}$ & $\begin{array}{c}0.273^{* * *} \\
(0.013)\end{array}$ & $\begin{array}{c}0.368^{* * *} \\
(0.012)\end{array}$ & $\begin{array}{c}0.458^{* * *} \\
(0.020)\end{array}$ & $\begin{array}{c}0.104^{* * *} \\
(0.014)\end{array}$ & $\begin{array}{c}0.598^{* * *} \\
(0.086)\end{array}$ & $\begin{array}{c}0.403^{* * *} \\
(0.071)\end{array}$ & $\begin{array}{c}0.517^{* * *} \\
(0.043)\end{array}$ & $\begin{array}{c}0.830^{* * *} \\
(0.127)\end{array}$ & $\begin{array}{c}0.155^{* * *} \\
(0.049)\end{array}$ \\
\hline Age - $\min ($ age) squared & $\begin{array}{c}-0.004^{* * *} \\
(0.000)\end{array}$ & $\begin{array}{c}-0.006^{* * *} \\
(0.000)\end{array}$ & $\begin{array}{c}-0.006^{* * *} \\
(0.000)\end{array}$ & $\begin{array}{c}-0.007^{* * *} \\
(0.000)\end{array}$ & $\begin{array}{c}-0.003^{* * *} \\
(0.000)\end{array}$ & $\begin{array}{c}-0.007^{* * *} \\
(0.001)\end{array}$ & $\begin{array}{c}-0.005^{* * *} \\
(0.001)\end{array}$ & $\begin{array}{c}-0.007^{* * *} \\
(0.001)\end{array}$ & $\begin{array}{c}-0.009^{* * *} \\
(0.001)\end{array}$ & $\begin{array}{c}-0.003^{* * *} \\
(0.001)\end{array}$ \\
\hline Female $=1$ & $\begin{array}{c}-2.914^{* * *} \\
(0.108)\end{array}$ & $\begin{array}{c}-5.471^{* * *} \\
(0.133)\end{array}$ & $\begin{array}{c}-5.849^{* * *} \\
(0.209)\end{array}$ & $\begin{array}{c}-5.520^{* * *} \\
(0.160)\end{array}$ & $\begin{array}{c}-3.487^{* * *} \\
(0.219)\end{array}$ & $\begin{array}{c}-4.811^{* * *} \\
(0.546)\end{array}$ & $\begin{array}{c}-3.823^{* * *} \\
(0.507)\end{array}$ & $\begin{array}{c}-4.022^{* * *} \\
(0.274)\end{array}$ & $\begin{array}{c}-5.759^{* * *} \\
(1.032)\end{array}$ & $\begin{array}{c}-2.344^{* * *} \\
(0.373)\end{array}$ \\
\hline Reads \& writes & $\begin{array}{c}0.266 \\
(0.177)\end{array}$ & $\begin{array}{c}0.071 \\
(0.159)\end{array}$ & $\begin{array}{c}0.898^{* * *} \\
(0.176)\end{array}$ & $\begin{array}{c}0.178 \\
(0.175)\end{array}$ & $\begin{array}{l}0.556^{* *} \\
(0.255)\end{array}$ & $\begin{array}{c}0.511 \\
(0.412)\end{array}$ & $\begin{array}{l}-0.270 \\
(0.391)\end{array}$ & $\begin{array}{l}0.595^{*} \\
(0.335)\end{array}$ & $\begin{array}{c}0.152 \\
(0.629)\end{array}$ & $\begin{array}{l}-0.632^{*} \\
(0.368)\end{array}$ \\
\hline Less than intermediate & $\begin{array}{c}0.152 \\
(0.144)\end{array}$ & $\begin{array}{l}-0.119 \\
(0.129)\end{array}$ & $\begin{array}{c}0.900^{* * *} \\
(0.146)\end{array}$ & $\begin{array}{l}-0.207 \\
(0.146)\end{array}$ & $\begin{array}{c}0.133 \\
(0.232)\end{array}$ & $\begin{array}{c}0.357 \\
(0.426)\end{array}$ & $\begin{array}{c}0.258 \\
(0.376)\end{array}$ & $\begin{array}{c}1.319^{* * *} \\
(0.330)\end{array}$ & $\begin{array}{l}-0.226 \\
(0.636)\end{array}$ & $\begin{array}{c}-0.353 \\
(0.370)\end{array}$ \\
\hline Intermediate & $\begin{array}{c}0.020 \\
(0.124)\end{array}$ & $\begin{array}{l}-0.154 \\
(0.112)\end{array}$ & $\begin{array}{c}1.462^{* * *} \\
(0.133)\end{array}$ & $\begin{array}{c}-0.389^{* * *} \\
(0.131)\end{array}$ & $\begin{array}{c}0.320 \\
(0.199)\end{array}$ & & & & & \\
\hline Above intermediate & $\begin{array}{c}1.265^{* * *} \\
(0.272)\end{array}$ & $\begin{array}{l}0.535^{* *} \\
(0.258)\end{array}$ & $\begin{array}{c}2.698^{* * *} \\
(0.263)\end{array}$ & $\begin{array}{c}0.408 \\
(0.299)\end{array}$ & $\begin{array}{c}1.811^{* * *} \\
(0.346)\end{array}$ & $\begin{array}{l}-0.194 \\
(0.461)\end{array}$ & $\begin{array}{l}-0.415 \\
(0.405)\end{array}$ & $\begin{array}{c}1.130^{* * *} \\
(0.338)\end{array}$ & $\begin{array}{l}-0.685 \\
(0.656)\end{array}$ & $\begin{array}{c}-0.801^{* *} \\
(0.370)\end{array}$ \\
\hline University+ & $\begin{array}{l}0.390^{* *} \\
(0.161)\end{array}$ & $\begin{array}{c}0.007 \\
(0.142)\end{array}$ & $\begin{array}{c}2.578^{* * *} \\
(0.159)\end{array}$ & $\begin{array}{c}0.196 \\
(0.170)\end{array}$ & $\begin{array}{c}1.721^{* * *} \\
(0.215)\end{array}$ & $\begin{array}{c}0.026 \\
(0.544)\end{array}$ & $\begin{array}{c}-0.994^{* *} \\
(0.499)\end{array}$ & $\begin{array}{c}1.628^{* * *} \\
(0.381)\end{array}$ & $\begin{array}{l}-1.427^{*} \\
(0.775)\end{array}$ & $\begin{array}{l}-0.147 \\
(0.404)\end{array}$ \\
\hline Reads \& writes $\times$ Female & $\begin{array}{c}-0.601^{* *} \\
(0.242)\end{array}$ & $\begin{array}{l}0.499^{*} \\
(0.296)\end{array}$ & $\begin{array}{l}0.735^{*} \\
(0.395)\end{array}$ & $\begin{array}{l}-0.393 \\
(0.614)\end{array}$ & $\begin{array}{c}0.508 \\
(0.365)\end{array}$ & & & & & \\
\hline Less than interm. $\times$ Female & $\begin{array}{c}-0.411^{* *} \\
(0.183)\end{array}$ & $\begin{array}{c}0.354 \\
(0.218)\end{array}$ & $\begin{array}{c}0.884^{* * *} \\
(0.288)\end{array}$ & $\begin{array}{l}-0.153 \\
(0.349)\end{array}$ & $\begin{array}{c}1.050^{* * *} \\
(0.297)\end{array}$ & $\begin{array}{c}0.343 \\
(0.695)\end{array}$ & $\begin{array}{l}-0.214 \\
(0.631)\end{array}$ & $\begin{array}{c}-0.463 \\
(0.338)\end{array}$ & $\begin{array}{c}-18.278^{* * *} \\
(1.055)\end{array}$ & $\begin{array}{l}-0.117 \\
(0.451)\end{array}$ \\
\hline Intermediate $\times$ Female & $\begin{array}{l}-0.279^{*} \\
(0.146)\end{array}$ & $\begin{array}{c}0.803^{* * *} \\
(0.171)\end{array}$ & $\begin{array}{c}2.725^{* * *} \\
(0.222)\end{array}$ & $\begin{array}{c}0.164 \\
(0.268)\end{array}$ & $\begin{array}{c}2.542^{* * *} \\
(0.240)\end{array}$ & & & & & \\
\hline Above interm. $\times$ Female & $\begin{array}{c}-2.400^{* * *} \\
(0.512)\end{array}$ & $\begin{array}{l}0.724^{*} \\
(0.377)\end{array}$ & $\begin{array}{c}2.299^{* * *} \\
(0.337)\end{array}$ & $\begin{array}{c}0.031 \\
(0.657)\end{array}$ & $\begin{array}{c}1.672^{* * *} \\
(0.382)\end{array}$ & $\begin{array}{c}0.025 \\
(0.848)\end{array}$ & $\begin{array}{c}0.597 \\
(0.608)\end{array}$ & $\begin{array}{c}0.978^{* * *} \\
(0.323)\end{array}$ & $\begin{array}{c}0.697 \\
(1.273)\end{array}$ & $\begin{array}{l}1.126^{* *} \\
(0.441)\end{array}$ \\
\hline University $\times$ Female & $\begin{array}{c}-0.750^{* * *} \\
(0.274)\end{array}$ & $\begin{array}{c}2.283^{* * *} \\
(0.202)\end{array}$ & $\begin{array}{c}3.627^{* * *} \\
(0.233)\end{array}$ & $\begin{array}{l}0.711^{*} \\
(0.394)\end{array}$ & $\begin{array}{c}2.327^{* * *} \\
(0.246)\end{array}$ & $\begin{array}{c}1.057 \\
(0.997)\end{array}$ & $\begin{array}{c}2.097^{* * *} \\
(0.715)\end{array}$ & $\begin{array}{c}2.616^{* * *} \\
(0.337)\end{array}$ & $\begin{array}{c}2.186 \\
(1.518)\end{array}$ & $\begin{array}{c}1.880^{* * * *} \\
(0.450)\end{array}$ \\
\hline Household wealth & $\begin{array}{c}-0.185^{* * *} \\
(0.039)\end{array}$ & $\begin{array}{c}-0.388^{* * *} \\
(0.038)\end{array}$ & $\begin{array}{c}-0.118^{* * *} \\
(0.041)\end{array}$ & $\begin{array}{c}0.053 \\
(0.054)\end{array}$ & $\begin{array}{c}-0.198^{* * *} \\
(0.045)\end{array}$ & $\begin{array}{c}0.143 \\
(0.119)\end{array}$ & $\begin{array}{l}-0.104 \\
(0.107)\end{array}$ & $\begin{array}{l}-0.106 \\
(0.068)\end{array}$ & $\begin{array}{c}0.673^{* * *} \\
(0.209)\end{array}$ & $\begin{array}{c}-0.183^{* *} \\
(0.085)\end{array}$ \\
\hline Household size & $\begin{array}{c}0.043^{* * *} \\
(0.012)\end{array}$ & $\begin{array}{c}0.030^{* * *} \\
(0.011)\end{array}$ & $\begin{array}{l}-0.021^{*} \\
(0.012)\end{array}$ & $\begin{array}{c}0.006 \\
(0.016)\end{array}$ & $\begin{array}{l}-0.013 \\
(0.012)\end{array}$ & $\begin{array}{c}-0.034 \\
(0.042)\end{array}$ & $\begin{array}{l}-0.014 \\
(0.033)\end{array}$ & $\begin{array}{c}-0.008 \\
(0.021)\end{array}$ & $\begin{array}{c}0.056 \\
(0.054)\end{array}$ & $\begin{array}{c}0.038 \\
(0.028)\end{array}$ \\
\hline Female-headed hhd & $\begin{array}{l}-0.070 \\
(0.082)\end{array}$ & $\begin{array}{c}0.242^{* * *} \\
(0.075)\end{array}$ & $\begin{array}{l}0.130^{*} \\
(0.074)\end{array}$ & $\begin{array}{c}0.354^{* * *} \\
(0.114)\end{array}$ & $\begin{array}{l}0.134^{*} \\
(0.080)\end{array}$ & $\begin{array}{l}-0.637 \\
(0.488)\end{array}$ & $\begin{array}{c}0.167 \\
(0.335)\end{array}$ & $\begin{array}{l}0.376^{*} \\
(0.218)\end{array}$ & $\begin{array}{c}0.413 \\
(0.840)\end{array}$ & $\begin{array}{l}0.540^{*} \\
(0.295)\end{array}$ \\
\hline Highest yrs. of ed. in hhd. & $\begin{array}{c}-0.042^{* * *} \\
(0.010)\end{array}$ & $\begin{array}{c}-0.058^{* * *} \\
(0.009)\end{array}$ & $\begin{array}{l}-0.010 \\
(0.012)\end{array}$ & $\begin{array}{c}-0.034^{* * *} \\
(0.013)\end{array}$ & $\begin{array}{c}-0.058^{* * *} \\
(0.013)\end{array}$ & $\begin{array}{c}-0.052 \\
(0.040)\end{array}$ & $\begin{array}{c}-0.031 \\
(0.036)\end{array}$ & $\begin{array}{c}0.076^{* * *} \\
(0.025)\end{array}$ & $\begin{array}{l}-0.017 \\
(0.059)\end{array}$ & $\begin{array}{l}0.078^{* *} \\
(0.033)\end{array}$ \\
\hline Father reads \& writes & $\begin{array}{l}-0.078 \\
(0.064)\end{array}$ & $\begin{array}{l}-0.117^{*} \\
(0.065)\end{array}$ & $\begin{array}{c}0.039 \\
(0.066)\end{array}$ & $\begin{array}{l}-0.029 \\
(0.083)\end{array}$ & $\begin{array}{l}-0.058 \\
(0.079)\end{array}$ & $\begin{array}{c}0.232 \\
(0.214)\end{array}$ & $\begin{array}{c}0.163 \\
(0.196)\end{array}$ & $\begin{array}{c}0.168 \\
(0.124)\end{array}$ & $\begin{array}{l}0.562^{* *} \\
(0.286)\end{array}$ & $\begin{array}{c}0.075 \\
(0.164)\end{array}$ \\
\hline Father <intermediate & $\begin{array}{l}-0.151^{*} \\
(0.091)\end{array}$ & $\begin{array}{c}-0.175^{* *} \\
(0.082)\end{array}$ & $\begin{array}{c}0.039 \\
(0.079)\end{array}$ & $\begin{array}{l}-0.018 \\
(0.117)\end{array}$ & $\begin{array}{c}0.026 \\
(0.090)\end{array}$ & $\begin{array}{l}-0.122 \\
(0.476)\end{array}$ & $\begin{array}{l}0.773^{* *} \\
(0.306)\end{array}$ & $\begin{array}{l}0.370^{*} \\
(0.198)\end{array}$ & $\begin{array}{l}-0.156 \\
(0.770)\end{array}$ & $\begin{array}{l}0.476^{* *} \\
(0.218)\end{array}$ \\
\hline Father intermediate+ & $\begin{array}{c}-0.361^{* * *} \\
(0.115)\end{array}$ & $\begin{array}{c}-0.511^{* * *} \\
(0.096)\end{array}$ & $\begin{array}{l}-0.044 \\
(0.084)\end{array}$ & $\begin{array}{l}-0.108 \\
(0.143)\end{array}$ & $\begin{array}{l}-0.010 \\
(0.095)\end{array}$ & $\begin{array}{c}0.541 \\
(0.330)\end{array}$ & $\begin{array}{c}0.361 \\
(0.262)\end{array}$ & $\begin{array}{c}0.075 \\
(0.164)\end{array}$ & $\begin{array}{l}0.932^{*} \\
(0.488)\end{array}$ & $\begin{array}{c}0.095 \\
(0.200)\end{array}$ \\
\hline Father university+ & $\begin{array}{c}-0.624^{* * *} \\
(0.177)\end{array}$ & $\begin{array}{c}-0.757^{* * *} \\
(0.133)\end{array}$ & $\begin{array}{l}-0.137 \\
(0.111)\end{array}$ & $\begin{array}{c}0.004 \\
(0.199)\end{array}$ & $\begin{array}{l}-0.177 \\
(0.128)\end{array}$ & $\begin{array}{l}0.800^{*} \\
(0.417)\end{array}$ & $\begin{array}{c}0.597 \\
(0.370)\end{array}$ & $\begin{array}{c}0.006 \\
(0.216)\end{array}$ & $\begin{array}{l}1.323^{* *} \\
(0.665)\end{array}$ & $\begin{array}{c}0.311 \\
(0.261)\end{array}$ \\
\hline Father employer & $\begin{array}{c}0.470^{* * *} \\
(0.058)\end{array}$ & $\begin{array}{c}-0.171^{* * *} \\
(0.058)\end{array}$ & $\begin{array}{c}-0.169^{* * *} \\
(0.056)\end{array}$ & $\begin{array}{c}0.691^{* * *} \\
(0.076)\end{array}$ & $\begin{array}{c}-0.219^{* * *} \\
(0.075)\end{array}$ & $\begin{array}{c}0.332 \\
(0.302)\end{array}$ & $\begin{array}{c}0.308 \\
(0.283)\end{array}$ & $\begin{array}{l}-0.305 \\
(0.189)\end{array}$ & $\begin{array}{l}0.724^{*} \\
(0.434)\end{array}$ & $\begin{array}{c}-0.199 \\
(0.265)\end{array}$ \\
\hline Father self-employed & $\begin{array}{c}0.204^{* * *} \\
(0.073)\end{array}$ & $\begin{array}{c}-0.148^{* *} \\
(0.075)\end{array}$ & $\begin{array}{c}-0.330^{* * *} \\
(0.074)\end{array}$ & $\begin{array}{l}0.198^{* *} \\
(0.099)\end{array}$ & $\begin{array}{l}-0.143 \\
(0.091)\end{array}$ & $\begin{array}{c}0.526^{* * *} \\
(0.200)\end{array}$ & $\begin{array}{c}0.204 \\
(0.175)\end{array}$ & $\begin{array}{l}-0.195 \\
(0.126)\end{array}$ & $\begin{array}{c}0.888^{* * *} \\
(0.274)\end{array}$ & $\begin{array}{l}-0.185 \\
(0.167)\end{array}$ \\
\hline Father unpaid fam. wrkr./non-employed & $\begin{array}{l}-0.130 \\
(0.146)\end{array}$ & $\begin{array}{l}0.289^{* *} \\
(0.117)\end{array}$ & $\begin{array}{c}0.188 \\
(0.121)\end{array}$ & $\begin{array}{c}0.045 \\
(0.199)\end{array}$ & $\begin{array}{l}0.203^{*} \\
(0.123)\end{array}$ & $\begin{array}{c}0.024 \\
(0.390)\end{array}$ & $\begin{array}{l}-0.110 \\
(0.364)\end{array}$ & $\begin{array}{l}-0.082 \\
(0.210)\end{array}$ & $\begin{array}{c}0.496 \\
(0.638)\end{array}$ & $\begin{array}{l}-0.252 \\
(0.321)\end{array}$ \\
\hline Rural residence & $\begin{array}{c}-0.003 \\
(0.078)\end{array}$ & $\begin{array}{c}0.038 \\
(0.075)\end{array}$ & $\begin{array}{c}0.045 \\
(0.076)\end{array}$ & $\begin{array}{c}0.013 \\
(0.105)\end{array}$ & $\begin{array}{l}0.150^{*} \\
(0.083)\end{array}$ & $\begin{array}{c}-0.494^{* * *} \\
(0.184)\end{array}$ & $\begin{array}{c}-0.793^{* * *} \\
(0.171)\end{array}$ & $\begin{array}{c}0.053 \\
(0.095)\end{array}$ & $\begin{array}{c}-1.011^{* * *} \\
(0.330)\end{array}$ & $\begin{array}{l}-0.191 \\
(0.126)\end{array}$ \\
\hline Region indicators & Y & Y & $\mathrm{Y}$ & Y & $\mathrm{Y}$ & $\mathrm{Y}$ & $\mathrm{Y}$ & $\mathrm{Y}$ & $\mathrm{Y}$ & $\mathrm{Y}$ \\
\hline Round 2012 & $\begin{array}{c}-0.321^{* * *} \\
(0.060)\end{array}$ & $\begin{array}{c}0.263^{* * *} \\
(0.065)\end{array}$ & $\begin{array}{c}-0.433^{* * *} \\
(0.050)\end{array}$ & $\begin{array}{c}-0.508^{* * *} \\
(0.074)\end{array}$ & $\begin{array}{c}-0.198^{* * *} \\
(0.075)\end{array}$ & & & & & \\
\hline Round 2018 & $\begin{array}{c}-0.522^{* * *} \\
(0.069)\end{array}$ & $\begin{array}{c}0.255^{* * *} \\
(0.071)\end{array}$ & $\begin{array}{c}-1.045^{* * *} \\
(0.062)\end{array}$ & $\begin{array}{c}-1.233^{* * *} \\
(0.088)\end{array}$ & $\begin{array}{c}-0.248^{* * *} \\
(0.079)\end{array}$ & & & & & \\
\hline Constant & $\begin{array}{c}-2.527^{* * *} \\
(0.262)\end{array}$ & $\begin{array}{c}-1.008^{* * *} \\
(0.262)\end{array}$ & $\begin{array}{c}-4.137^{* * *} \\
(0.262)\end{array}$ & $\begin{array}{c}-5.444^{* * *} \\
(0.374)\end{array}$ & $\begin{array}{c}-1.292^{* * *} \\
(0.300)\end{array}$ & $\begin{array}{c}-3.508^{* * *} \\
(0.880)\end{array}$ & $\begin{array}{c}-1.760^{* *} \\
(0.736)\end{array}$ & $\begin{array}{c}-2.955^{* * *} \\
(0.517)\end{array}$ & $\begin{array}{c}-7.547^{* * *} \\
(1.362)\end{array}$ & $\begin{array}{c}-1.908^{* * *} \\
(0.609)\end{array}$ \\
\hline $\begin{array}{l}\text { Observations } \\
\text { Clusters }\end{array}$ & $\begin{array}{l}45,719 \\
11311\end{array}$ & $\begin{array}{l}45,719 \\
11311\end{array}$ & $\begin{array}{l}45,719 \\
11311\end{array}$ & $\begin{array}{l}45,719 \\
11311\end{array}$ & $\begin{array}{l}45,719 \\
11311\end{array}$ & 7,026 & 7,026 & 7,026 & 7,026 & 7,026 \\
\hline Chi-squared & 13480 & 13480 & 13480 & 13480 & 13480 & 30012 & 30012 & 30012 & 30012 & 30012 \\
\hline Pseudo R-squared & 0.312 & 0.312 & 0.312 & 0.312 & 0.312 & 0.267 & 0.267 & 0.267 & 0.267 & 0.267 \\
\hline
\end{tabular}

Note: robust standard errors clustered at individual level are in parentheses; ${ }^{\star * *} p<0.01,{ }^{* *} p<0.05,{ }^{*} p<0.1$.

Workers' status as 'youth' and all household-level variables are lagged by one survey wave to estimate the effect of workers' circumstances in their youth on their subsequent outcomes.

Source: authors' calculations based on ELMPS 1998-2018, JLMPS 2010-16 (OAMDI 2019). 
Table A4: Multinomial logit regressions of employment type: Tunisia, youth and non-youth jointly

\begin{tabular}{|c|c|c|c|c|c|}
\hline & \multirow{2}{*}{\multicolumn{5}{|c|}{ Tunisia 2014}} \\
\hline & & & & & \\
\hline & $\begin{array}{c}\text { Self- } \\
\text { empl./Unpaid } \\
\text { family wrkr. }\end{array}$ & $\begin{array}{l}\text { Informalt } \\
\text { irregular }\end{array}$ & $\begin{array}{l}\text { Public }+ \\
\text { formal } \\
\text { private }\end{array}$ & Employer & Unemployed \\
\hline \multirow[t]{2}{*}{ Youth $=1$} & $0.527^{* * *}$ & $0.427^{* * *}$ & $0.719^{* * *}$ & $0.859^{* *}$ & $0.886^{* * *}$ \\
\hline & $(0.180)$ & $(0.157)$ & (0.149) & $(0.384)$ & (0.189) \\
\hline \multirow[t]{2}{*}{ Age - $\min ($ age $)$} & $0.359^{* * *}$ & $0.348^{* * *}$ & $0.587^{* * *}$ & $0.738^{* * *}$ & $0.314^{* * *}$ \\
\hline & $(0.041)$ & $(0.038)$ & $(0.037)$ & $(0.093)$ & $(0.052)$ \\
\hline \multirow[t]{2}{*}{ Age - min(age) squared } & $-0.004^{* * *}$ & $-0.004^{* * *}$ & $-0.007^{* * *}$ & $-0.009^{* * *}$ & $-0.005^{* * *}$ \\
\hline & $(0.001)$ & $(0.001)$ & $(0.000)$ & $(0.001)$ & $(0.001)$ \\
\hline \multirow[t]{2}{*}{ Female $=1$} & $-2.590 * * *$ & $-3.006^{* * *}$ & $-2.737^{* * *}$ & $-3.720^{* * *}$ & $-1.943^{* * *}$ \\
\hline & (0.193) & $(0.208)$ & (0.182) & $(0.562)$ & $(0.230)$ \\
\hline \multirow[t]{2}{*}{ Reads \& writes } & $0.329^{*}$ & $0.532^{* * *}$ & $1.090^{* * *}$ & 0.450 & $0.412^{*}$ \\
\hline & $(0.183)$ & $(0.181)$ & $(0.198)$ & $(0.478)$ & $(0.249)$ \\
\hline \multirow[t]{2}{*}{ Primary } & $1.255^{* * *}$ & $1.073^{* * *}$ & $1.756^{* * *}$ & $1.718^{* * *}$ & $1.095^{* * *}$ \\
\hline & $(0.260)$ & $(0.237)$ & $(0.266)$ & $(0.512)$ & (0.308) \\
\hline \multirow[t]{2}{*}{ Preparatory } & $0.538^{*}$ & 0.117 & $1.525^{* * *}$ & 0.847 & 0.327 \\
\hline & $(0.295)$ & $(0.272)$ & $(0.282)$ & $(0.618)$ & $(0.358)$ \\
\hline \multirow[t]{2}{*}{ Secondary } & -0.527 & $-0.974^{* * *}$ & $1.676^{* * *}$ & 0.308 & -0.002 \\
\hline & $(0.334)$ & (0.335) & $(0.282)$ & $(0.585)$ & $(0.351)$ \\
\hline University short cycle & -0.420 & -0.707 & $2.505^{* * *}$ & -0.367 & $1.011^{* * *}$ \\
\hline & (0.589) & $(0.488)$ & $(0.332)$ & $(0.962)$ & $(0.364)$ \\
\hline University long cycle+ & $-2.003^{*}$ & -0.212 & $3.078^{* * *}$ & 0.061 & $1.605^{* * *}$ \\
\hline & $(1.072)$ & $(0.517)$ & $(0.343)$ & $(0.925)$ & $(0.378)$ \\
\hline Less than interm. $\times$ Female & $-1.191^{* * *}$ & $-0.864^{* * *}$ & -0.282 & $-2.833^{* *}$ & $-1.093^{* * *}$ \\
\hline & $(0.349)$ & $(0.334)$ & $(0.318)$ & $(1.227)$ & $(0.389)$ \\
\hline Intermediate $\times$ Female & -0.276 & 0.099 & 0.216 & -0.283 & -0.242 \\
\hline & $(0.418)$ & $(0.490)$ & $(0.332)$ & $(0.908)$ & $(0.389)$ \\
\hline University $\times$ Female & 0.193 & $1.148^{* *}$ & $0.577^{*}$ & $-22.202^{* * *}$ & $1.009^{* * *}$ \\
\hline & $(0.491)$ & $(0.488)$ & $(0.301)$ & $(0.681)$ & $(0.375)$ \\
\hline Household wealth & $-0.266^{* *}$ & $-0.667^{* * *}$ & 0.013 & $0.612^{* * *}$ & $-0.465^{* * *}$ \\
\hline & $(0.113)$ & $(0.118)$ & $(0.075)$ & $(0.175)$ & $(0.114)$ \\
\hline Household size & 0.036 & -0.033 & -0.043 & $-0.145^{*}$ & 0.038 \\
\hline & $(0.041)$ & $(0.041)$ & $(0.038)$ & $(0.079)$ & $(0.040)$ \\
\hline Female-headed hhd & 0.175 & 0.052 & 0.139 & -0.757 & 0.010 \\
\hline & $(0.336)$ & $(0.277)$ & $(0.269)$ & $(0.808)$ & $(0.275)$ \\
\hline Highest yrs. of ed. in hhd. & 0.011 & 0.007 & -0.018 & $0.054^{*}$ & $0.046^{* *}$ \\
\hline & $(0.020)$ & $(0.017)$ & $(0.017)$ & $(0.030)$ & $(0.021)$ \\
\hline Father reads \& writes & 0.108 & 0.206 & 0.102 & $-23.171^{* * *}$ & $0.749^{* * *}$ \\
\hline & (0.296) & (0.239) & (0.293) & $(0.522)$ & $(0.223)$ \\
\hline Father primary & -0.126 & 0.033 & 0.109 & 0.089 & -0.180 \\
\hline & $(0.186)$ & $(0.156)$ & $(0.135)$ & $(0.325)$ & $(0.192)$ \\
\hline Father preparatory & 0.066 & 0.048 & -0.038 & 0.223 & -0.111 \\
\hline & $(0.364)$ & $(0.291)$ & $(0.208)$ & $(0.482)$ & $(0.233)$ \\
\hline Father university short cycle & 0.225 & -0.128 & 0.297 & 1.295 & -0.328 \\
\hline & $(0.885)$ & $(0.829)$ & $(0.622)$ & $(1.610)$ & $(0.755)$ \\
\hline Father university long cycle & $-23.285^{* * *}$ & -0.864 & -0.064 & $-23.350^{* * *}$ & -0.914 \\
\hline & (0.449) & $(1.082)$ & $(0.506)$ & $(0.571)$ & $(0.736)$ \\
\hline Father post-graduate & $2.890^{*}$ & 3.067 & -0.623 & $-23.561^{* * *}$ & $-24.554^{* * *}$ \\
\hline & $(1.556)$ & (1.923) & $(0.851)$ & $(1.293)$ & (1.059) \\
\hline Father employer & $0.941^{* * *}$ & -0.410 & $-0.525^{* *}$ & $1.423^{* * *}$ & $-0.918^{* * *}$ \\
\hline & $(0.247)$ & $(0.282)$ & $(0.223)$ & $(0.347)$ & $(0.328)$ \\
\hline Father self-employed & $0.887^{* * *}$ & -0.191 & $-0.232^{*}$ & -0.261 & -0.187 \\
\hline & $(0.144)$ & $(0.142)$ & $(0.141)$ & (0.333) & $(0.177)$ \\
\hline Father unpaid fam. wrkr./non-employed & 0.110 & $-0.700^{* * *}$ & $-0.759 * * *$ & $-1.389^{* *}$ & -0.329 \\
\hline & $(0.275)$ & $(0.236)$ & $(0.247)$ & $(0.611)$ & $(0.206)$ \\
\hline Rural residence & $0.287^{*}$ & -0.139 & -0.027 & 0.182 & $-0.246^{*}$ \\
\hline & $(0.150)$ & (0.139) & $(0.126)$ & $(0.246)$ & $(0.138)$ \\
\hline Region indicators & 0.497 & 0.062 & $0.448^{* * *}$ & 0.397 & 0.386 \\
\hline Constant & $-4.278^{* * *}$ & $-1.200^{* * *}$ & $-3.700^{* * *}$ & $-6.610^{* * *}$ & $-2.601^{* * *}$ \\
\hline & $(0.486)$ & $(0.386)$ & $(0.415)$ & $(0.959)$ & $(0.442)$ \\
\hline Observations & 6,914 & 6,914 & 6,914 & 6,914 & 6,914 \\
\hline Chi-squared & 31903 & 31903 & 31903 & 31903 & 31903 \\
\hline Pseudo R-squared & 0.269 & 0.269 & 0.269 & 0.269 & 0.269 \\
\hline
\end{tabular}

Note: robust standard errors in parentheses; $* \star * p<0.01,{ }^{* *} p<0.05,{ }^{*} p<0.1$. Workers' status as 'youth' is lagged by six years (i.e. 'youth' are 21-35 years old in 2014) and region and rural/urban residence are from workers' birthplace to estimate the effect of workers' circumstances in their youth on their subsequent outcomes.

Source: authors' calculations based on TLMPS 2014 (OAMDI 2019). 
Figure A1a: Employment sector by age and gender, Egypt 1998

\section{Employment Status and Sector by age group in 1998}

\section{Males}

(non students)

Age 30 to 59

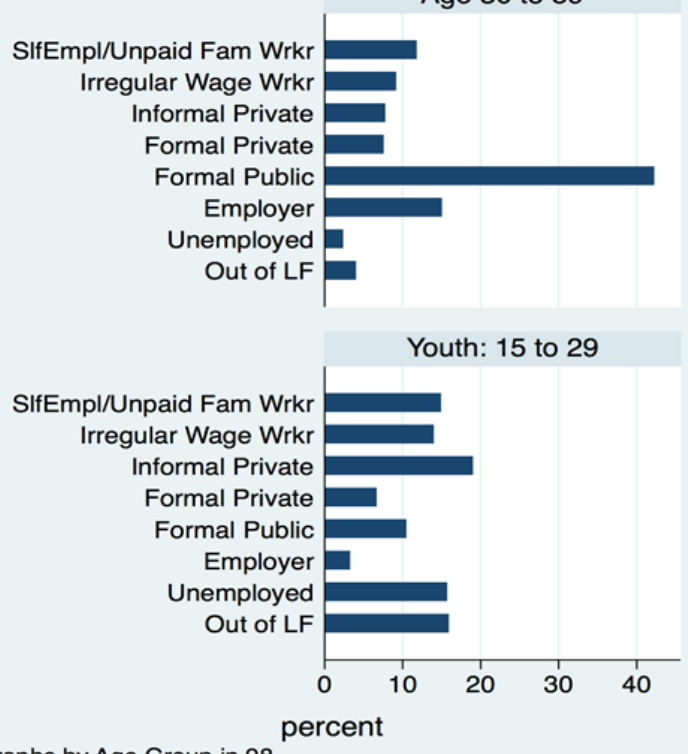

Females

(non students)

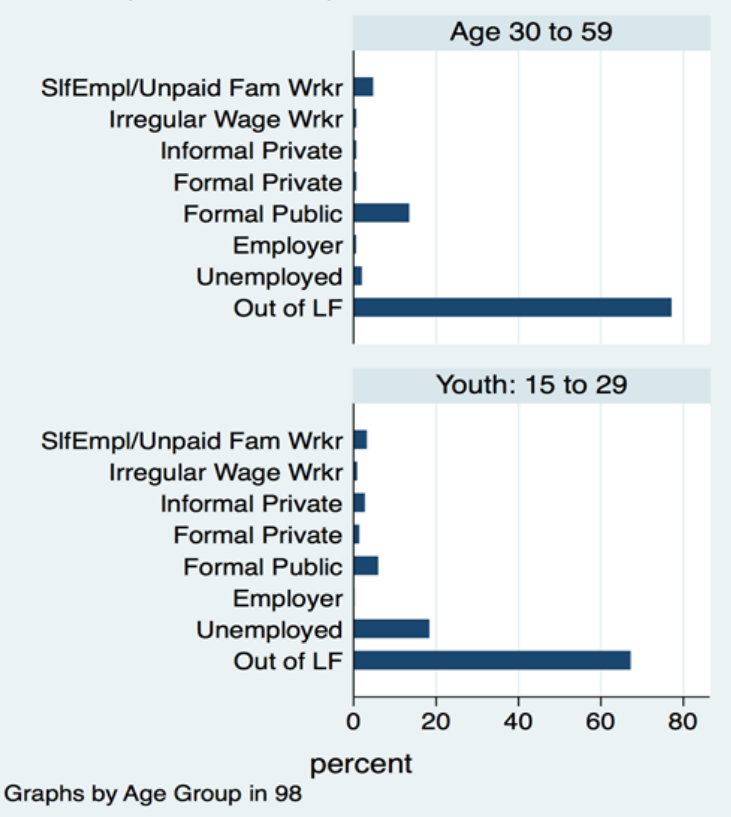

Source: authors' calculations based on ELMPS 1998 (OAMDI 2019). 
Figure A1b: Employment sector by age and gender, Egypt 2006

\section{Employment Status and Sector by age group in 2006}

Males

(non students)

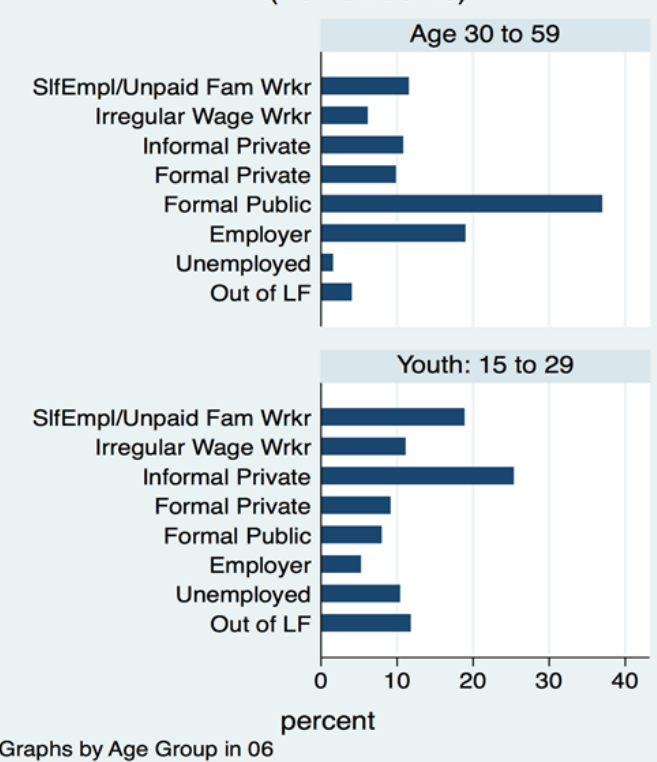

Females

(non students)

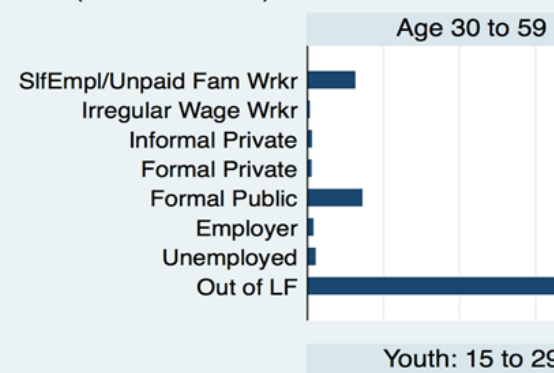

SlfEmpl/Unpaid Fam Wrkr Irregular Wage Wrkr Informal Private

Formal Private

Formal Public Employer Unemployed

Out of LF

Youth: 15 to 29

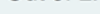

$\begin{array}{lllll}0 & 20 & 40 & 60 & 80 \\ \text { percent } & & & & \end{array}$

Source: authors' calculations based on ELMPS 2006 (OAMDI 2019). 
Figure A1c: Employment sector by age and gender, Egypt 2012

\section{Employment Status and Sector by age group in 2012}

Males

(non students)

Age 30 to 59

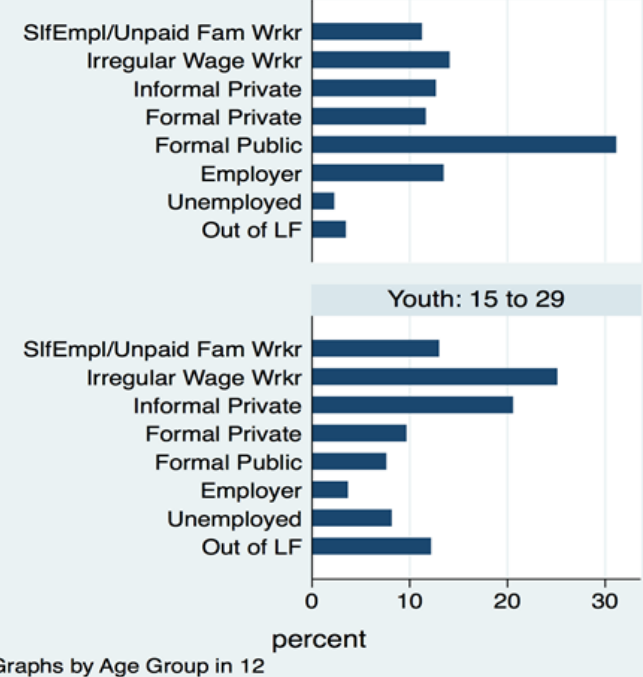

Females

(non students)

Age 30 to 59

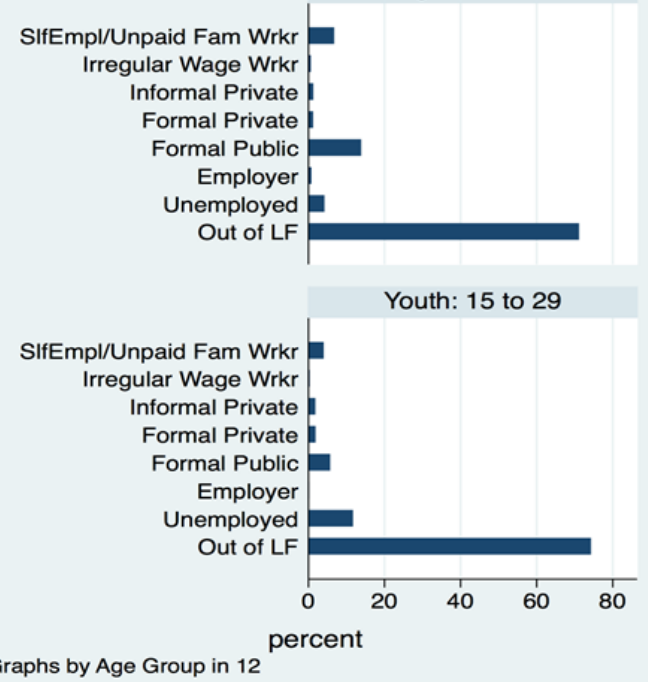

Source: authors' calculations based on ELMPS 2012 (OAMDI 2019). 
Figure A1d: Employment sector by age and gender, Egypt 2018

\section{Employment Status and Sector by age group in 2018}

Males (non students)

Age 30 to 59

SlfEmpl/Unpaid Fam Wrkr Irregular Wage Wrkr

Informal Private

Formal Private

Formal Public

Employer

Unemployed

Out of LF

Youth: 15 to 29

SlfEmpl/Unpaid Fam Wrkr Irregular Wage Wrkr Informal Private Formal Private Formal Public Employer

Unemployed Out of LF

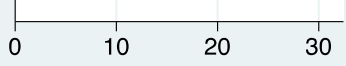

percent
Females (non students)

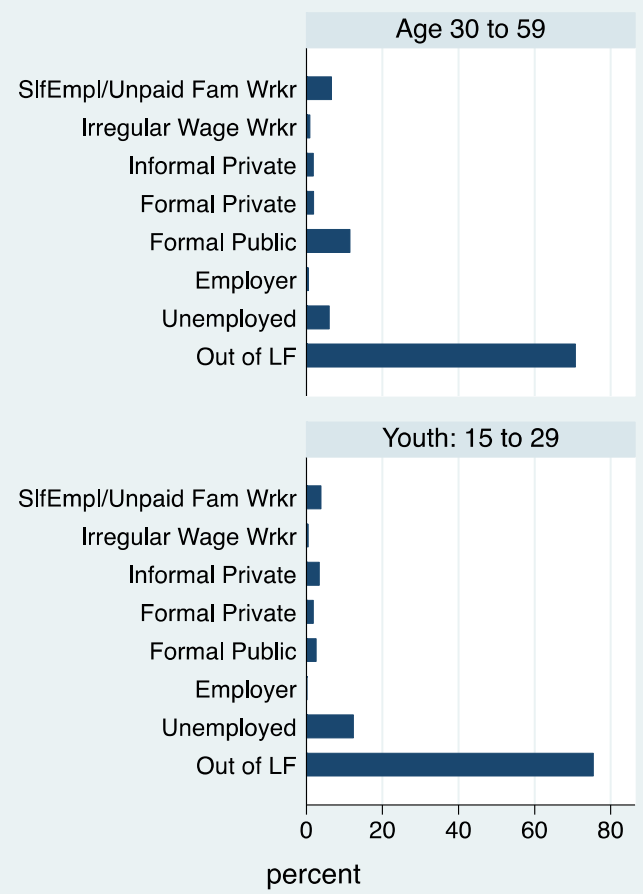

Source: authors' calculations based on ELMPS 2018 (OAMDI 2019). 
Figure A2a: Employment sector by age and gender, Jordan 2010

\section{Employment Status and Sector by age group in 2010}

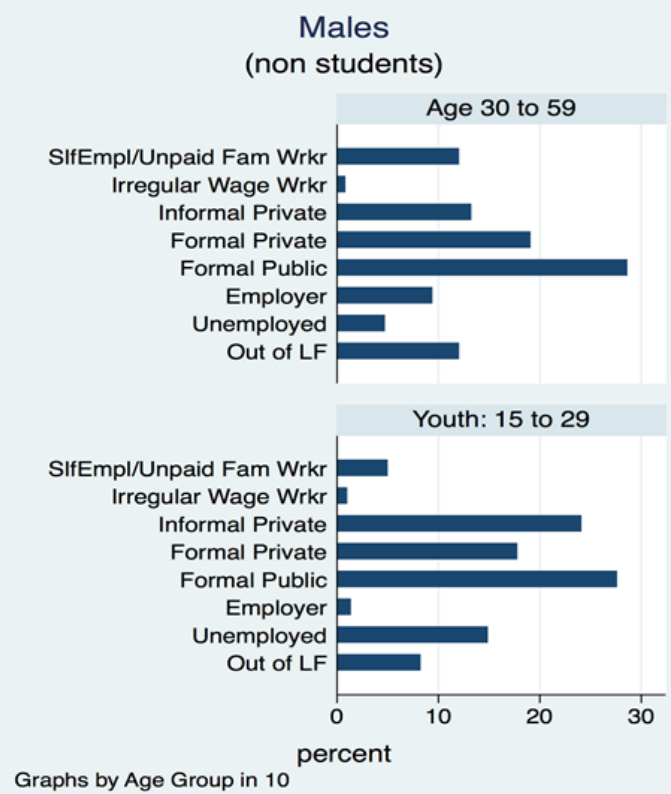

Females

(non students)

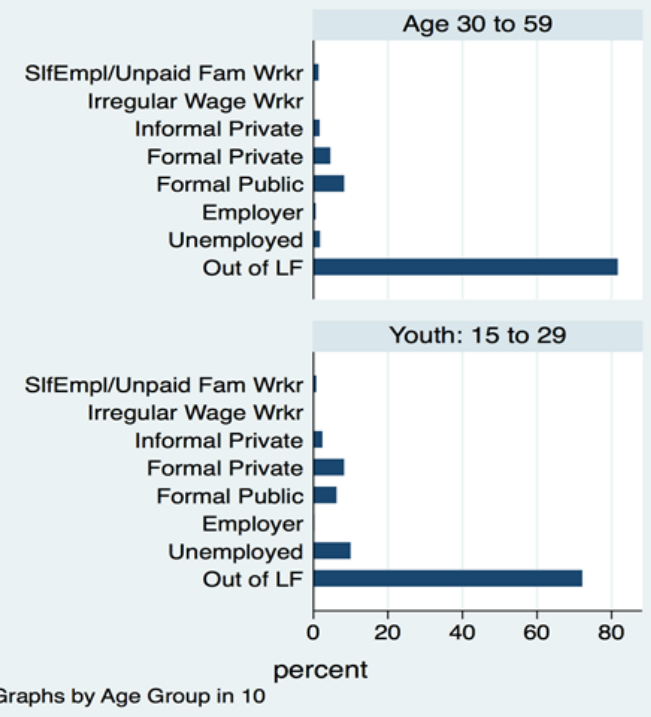

Source: authors' calculations based on JLMPS 2010 (OAMDI 2019). 
Figure A2b: Employment sector by age and gender, Jordan 2016

\section{Employment Status and Sector by age group in 2016}

Males

(non students)

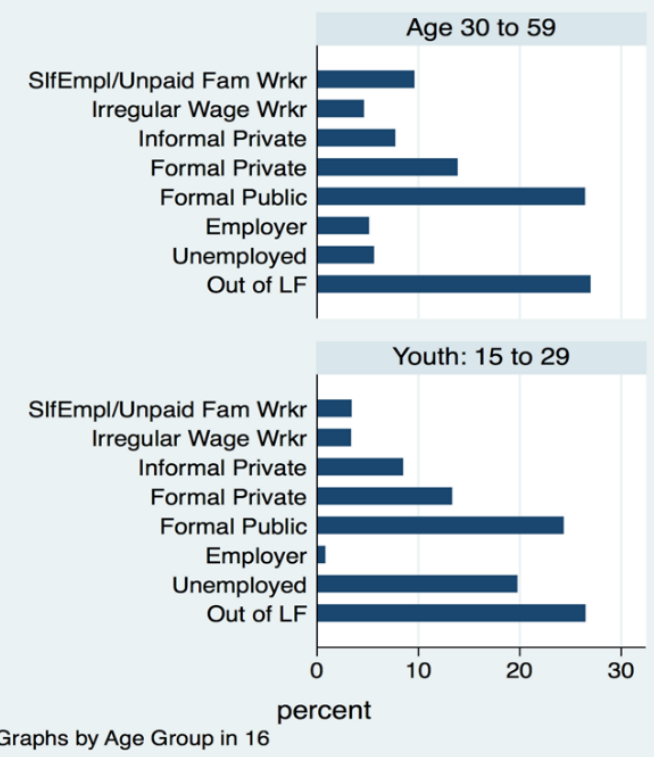

Females

(non students)

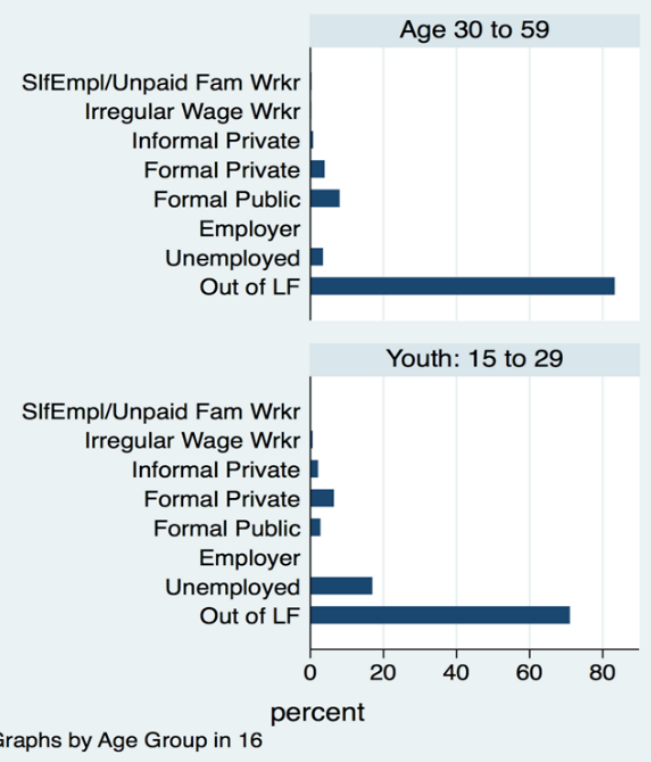

Source: authors' calculations based on JLMPS 2016 (OAMDI 2019). 
Figure A2c: Employment sector by age and gender, Tunisia 2014

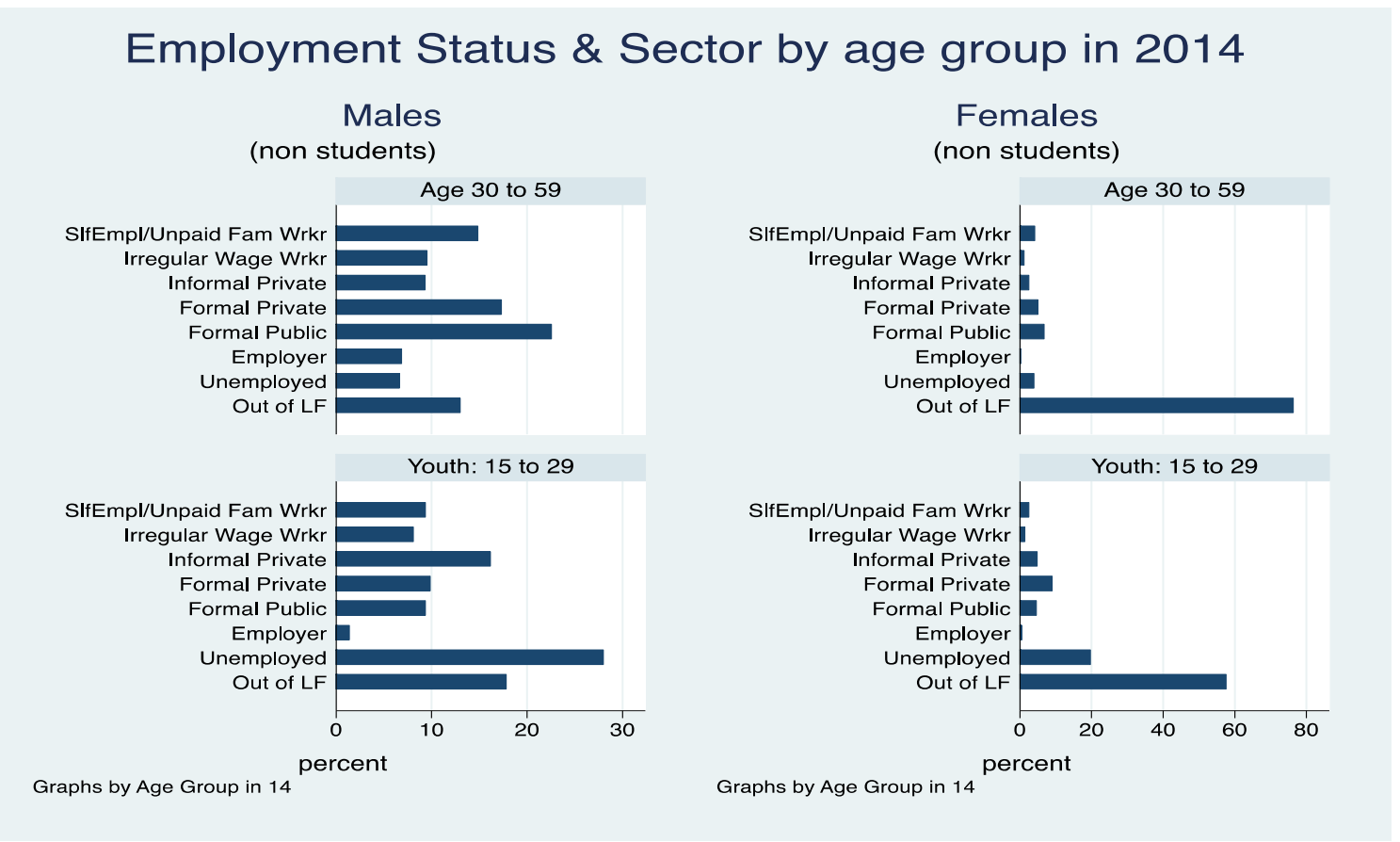

Source: authors' calculations based on TLMPS 2014 (OAMDI 2019). 
Figure A3: Longer employment transitions, male non-student youth, Egypt
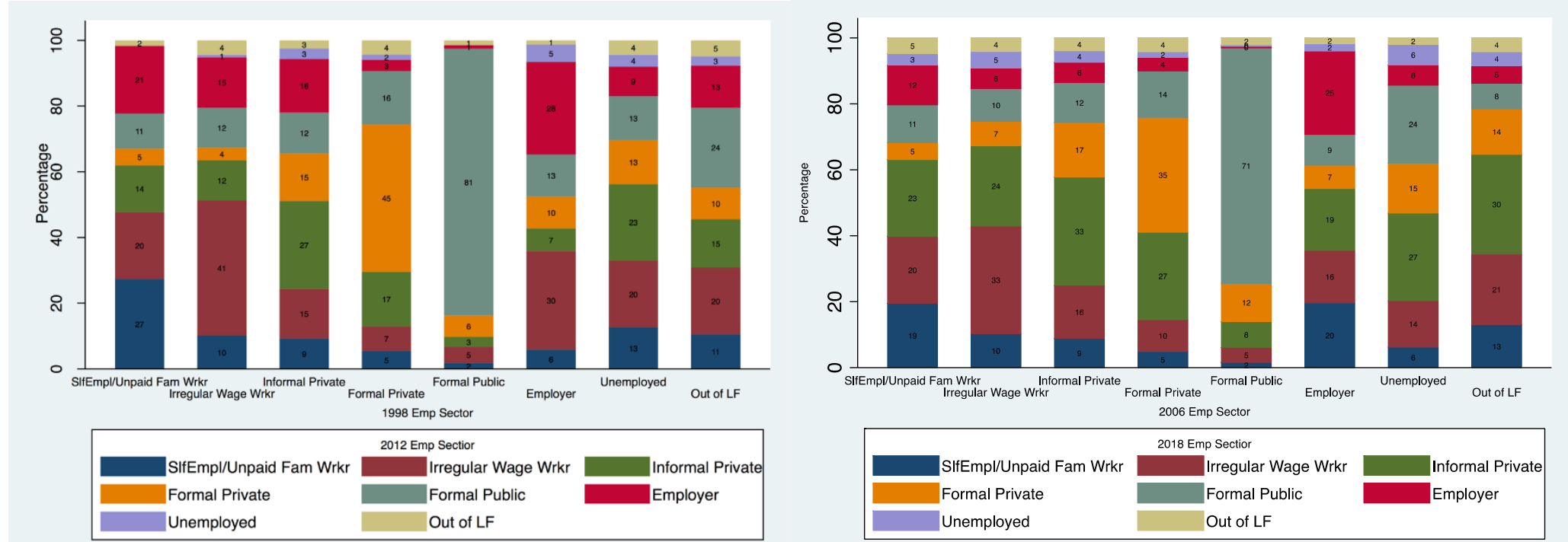

i. 1998-2012 Egypt

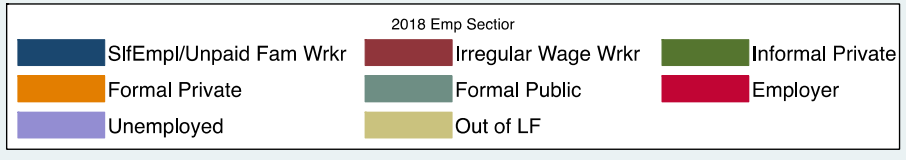

ii. 2006-18 Egypt

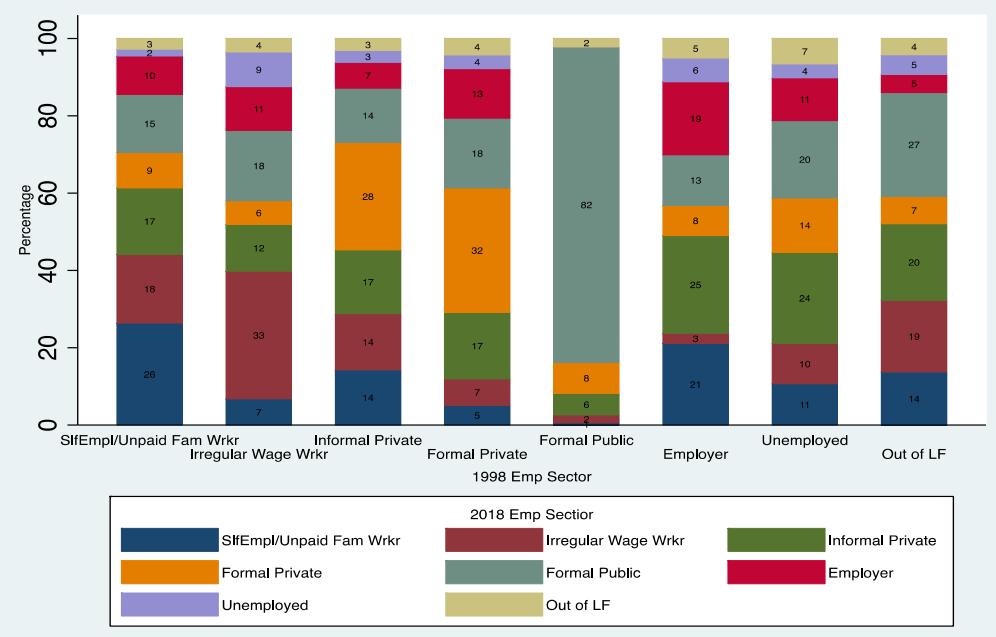

iii. 1998-2018 Egypt

Source: authors' calculations based on ELMPS 1998-2018 (OAMDI 2019). 
Figure A4: Employment sector by household wealth quintiles in prior years, for youth males

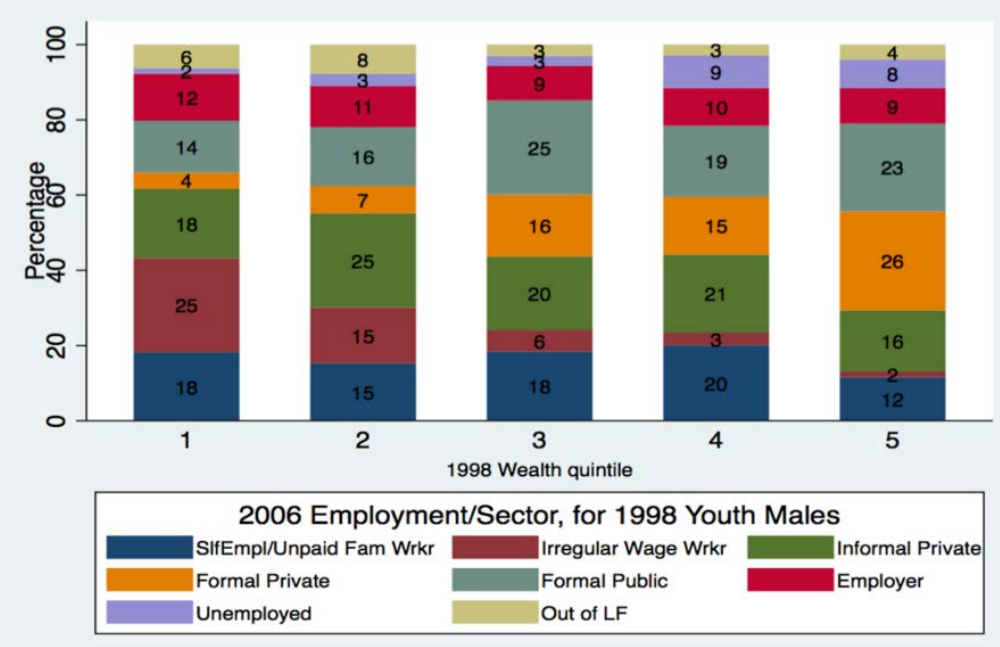

i. 2006 employment by 1998 wealth quintile, 1998 Egypt youth

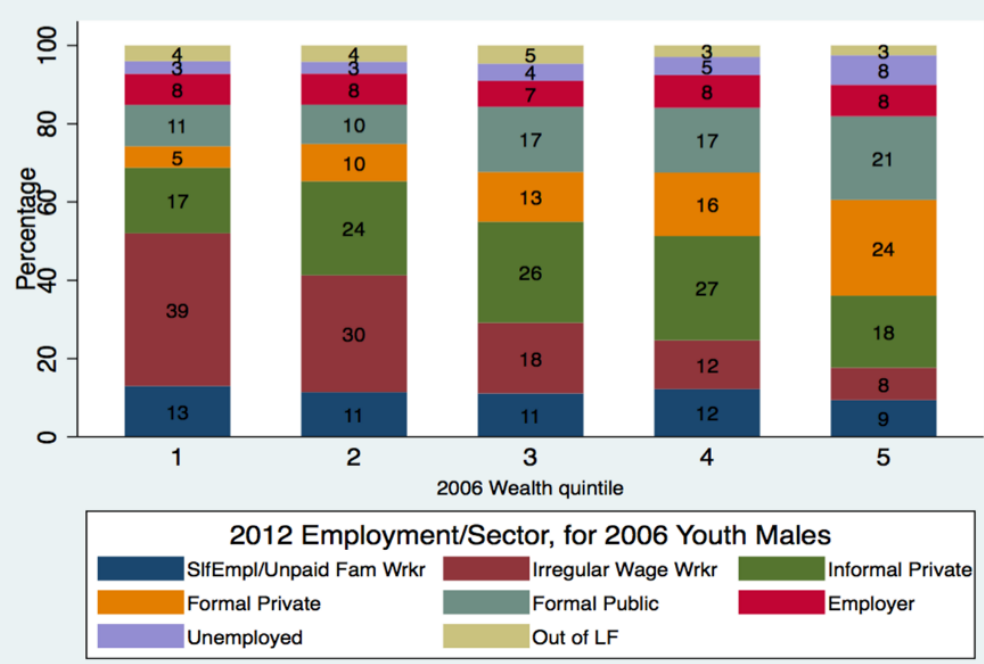

iii. 2012 employment by 2006 wealth quintile, 2006 Egypt youth

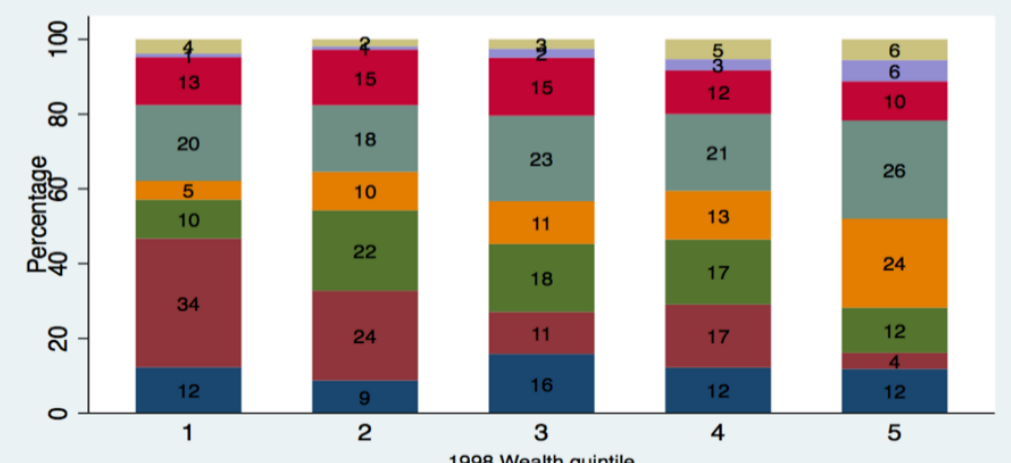

2012 Employment/Sector, for 1998 Youth Males SlifEmpl/Unpaid Fam Wrkr $\quad$ Irregular Wage Wrkr Informal Private Unemployed $\quad$ Formal Pub

ii. 2012 employment by 1998 wealth quintile, 1998 Egypt youth

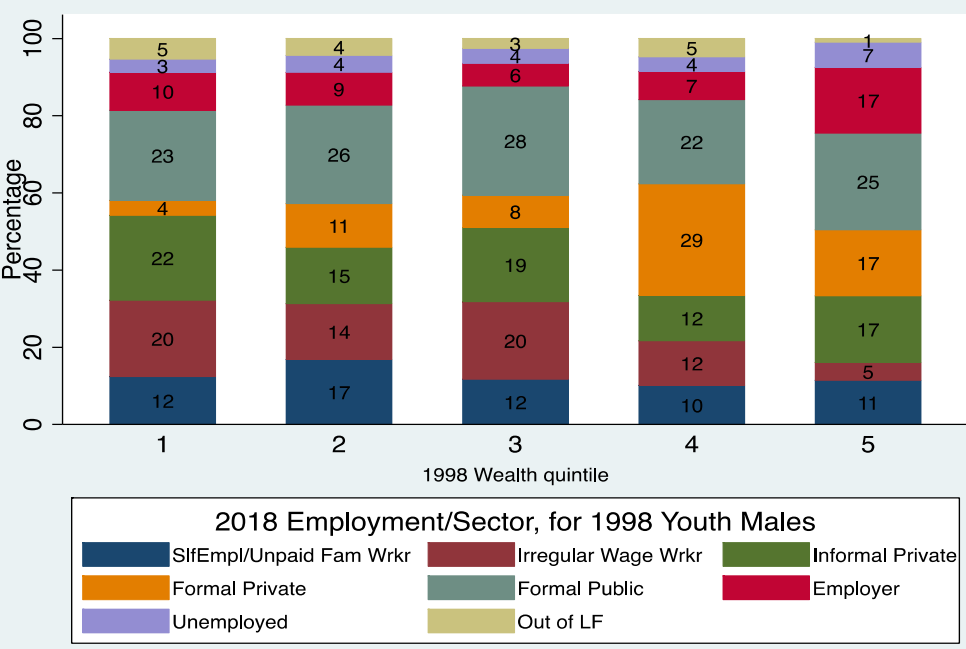

iv. 2018 employment by 1998 wealth quintile, 1998 Egypt youth 


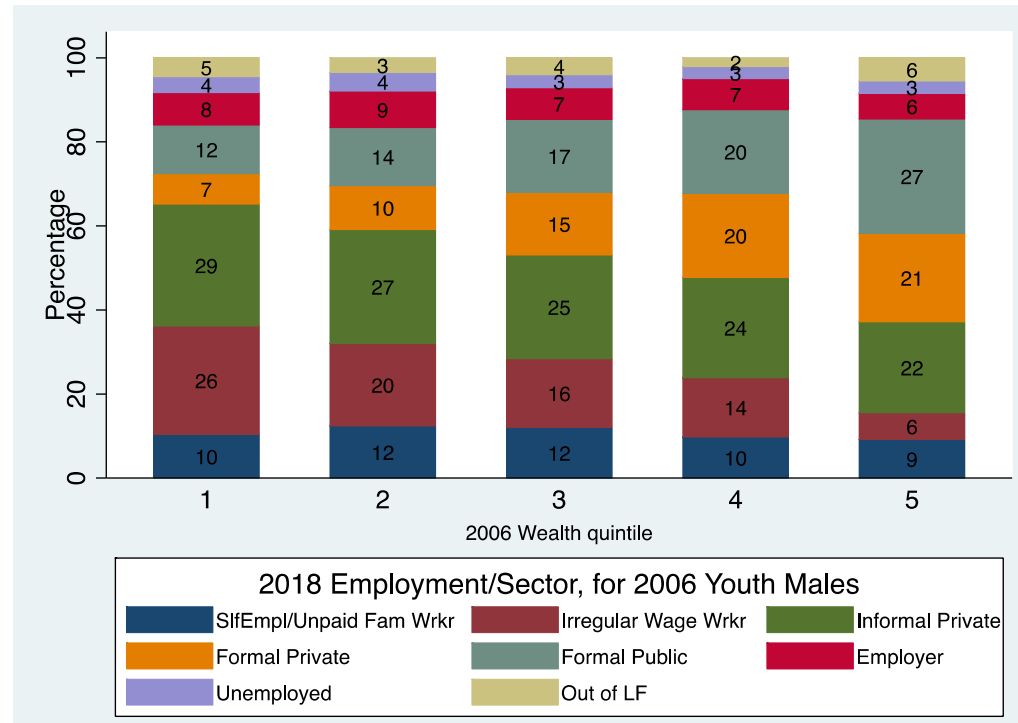

v. 2018 employment by 2006 wealth quintile, 2006 Egypt youth

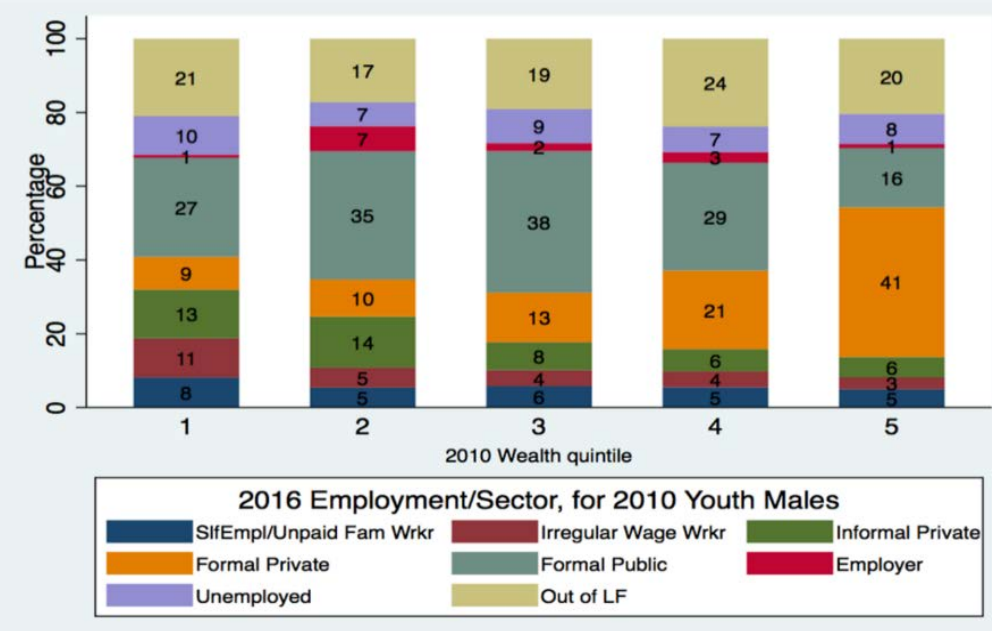

vii. 2016 employment by 2010 wealth quintile, 2010 Jordan youth

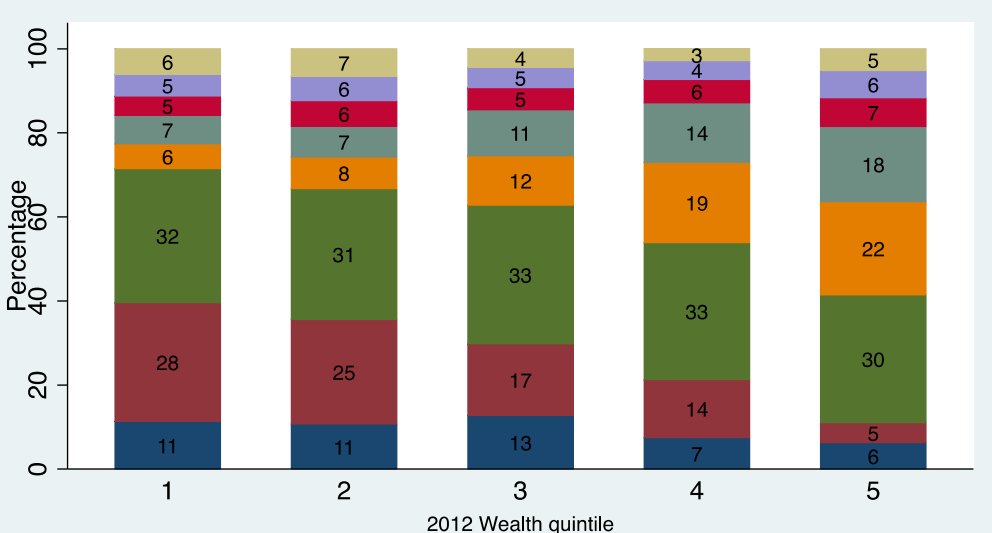

2012 Wealth quintile

2018 Employment/Sector, for 2012 Youth Males

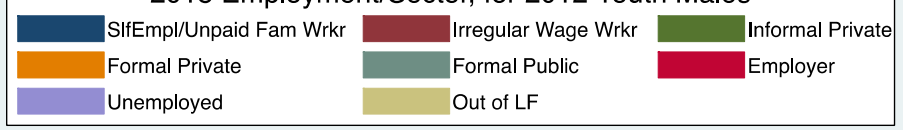

vi. 2018 employment by 2012 wealth quintile, for 2012 Egypt youth

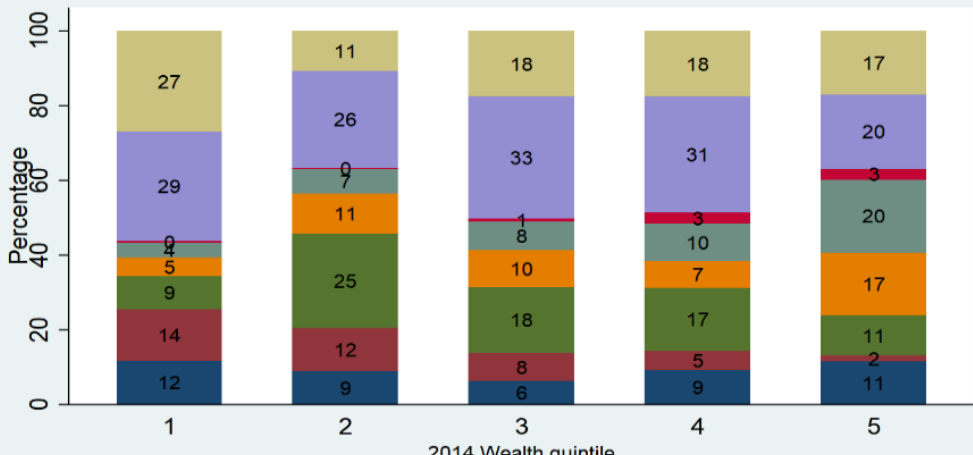

2014 Wealth quintile

2014 Employment Sector, for 2014 Youth Males

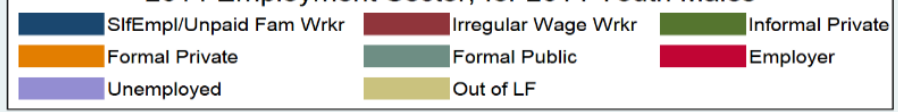

viii. 2014 employment by 2014 wealth quintile, 2014 Tunisia youth Source: authors' calculations based on ELMPS 1998-2018, JLMPS 2010-16, TLMPS 2014 (OAMDI 2019). 
Figure A5: Employment sector by fathers' education in prior years, for youth males

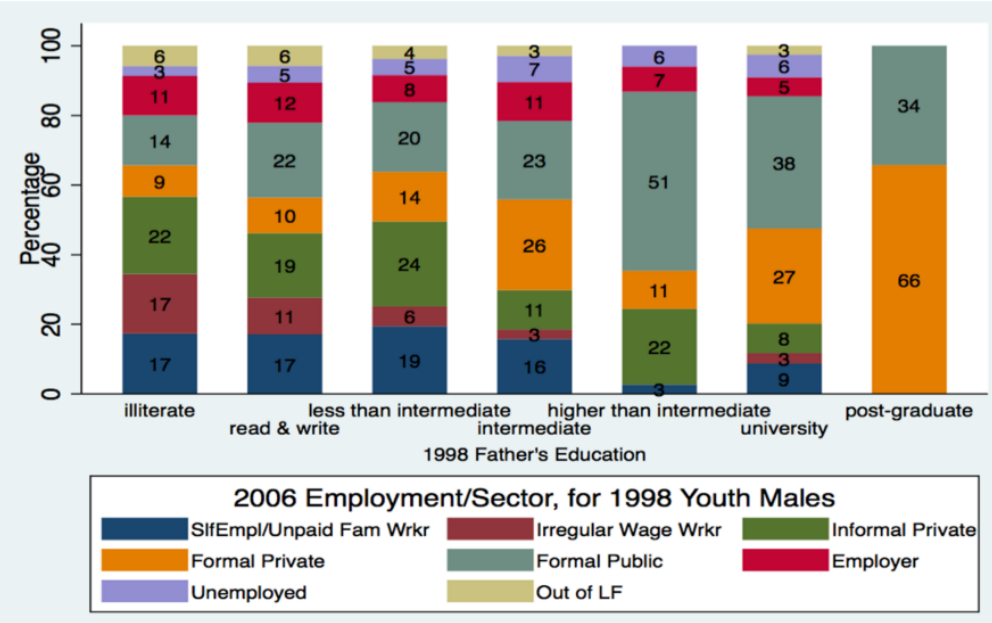

i. 2006 employment by father's education in 1998, 1998 Egypt youth

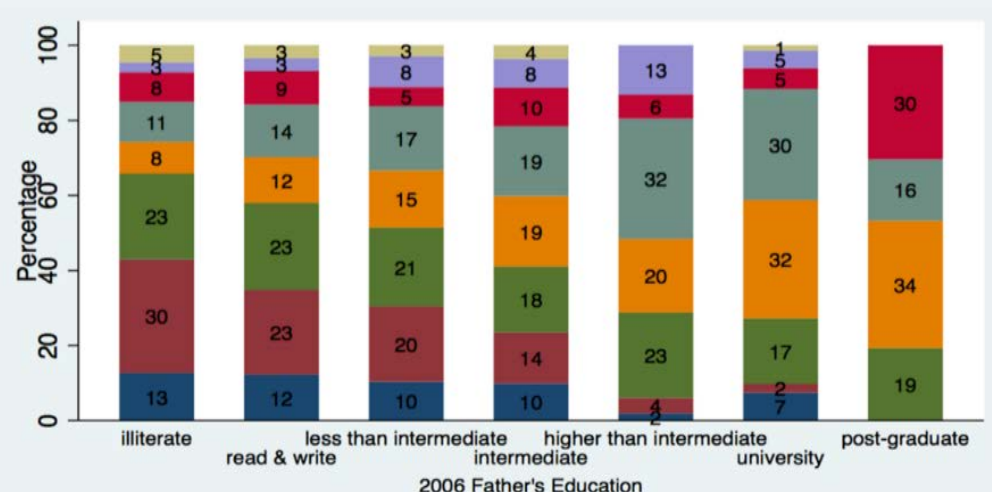

2012 Employment Sector, for 2006 Youth Males

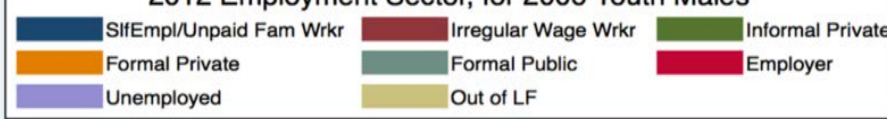

iii. 2012 employment by father's education in 2006, 2006 Egypt youth

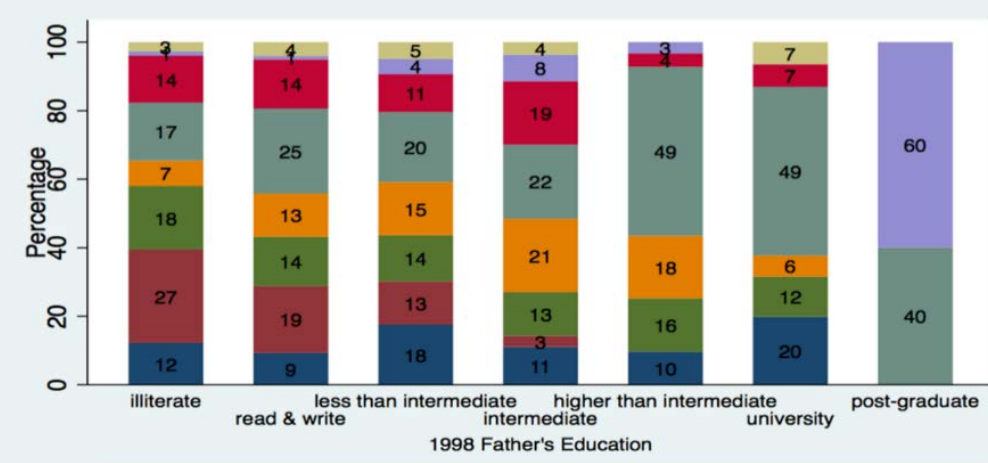

2012 Employment/Sector, for 1998 Youth Males

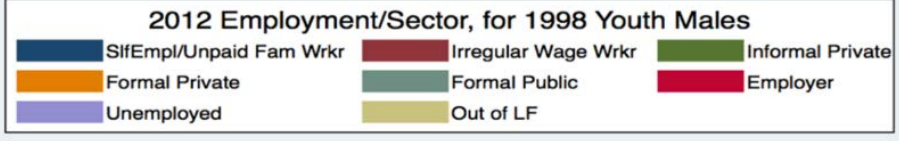

ii. 2012 employment by father's education in 1998, 1998 Egypt youth

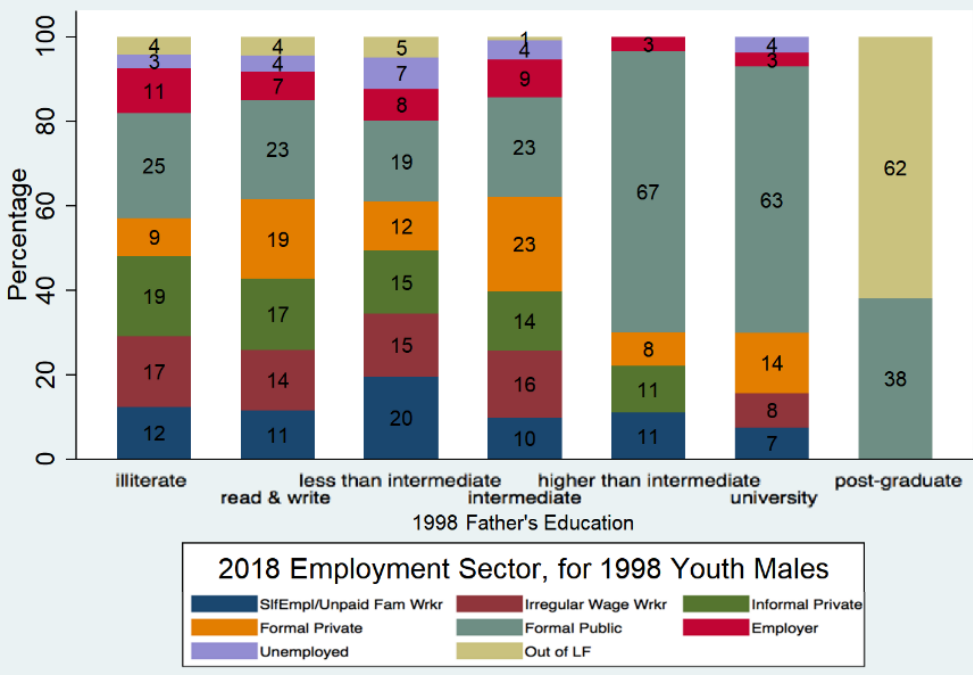

iv. 2018 employment by father's education in 1998, 1998 Egypt youth 


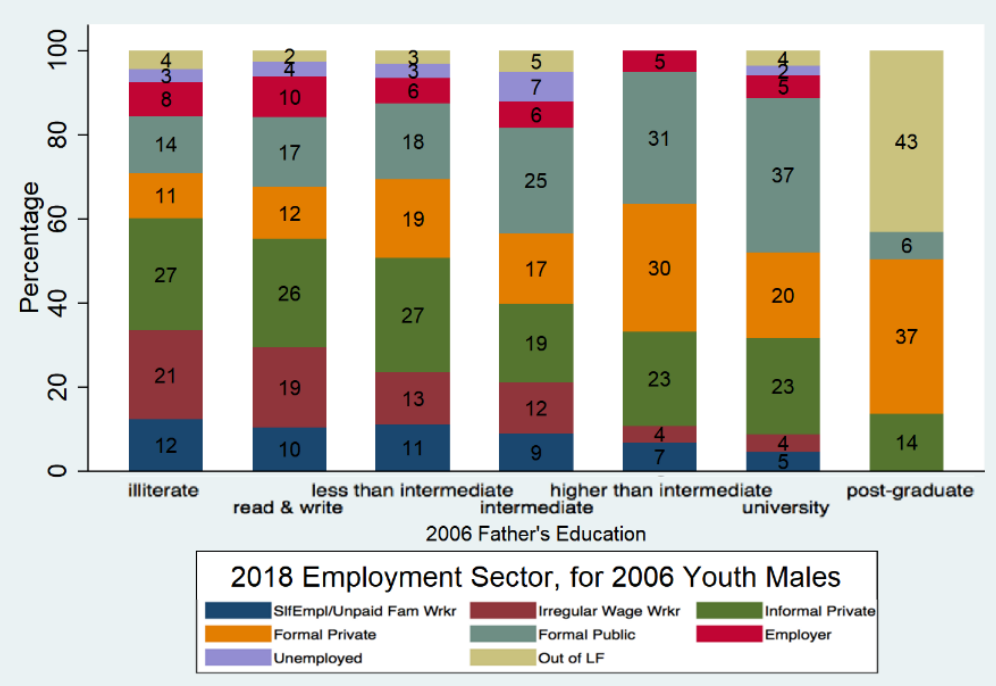

v. 2018 employment by father's education in 2006, 2006 Egypt youth

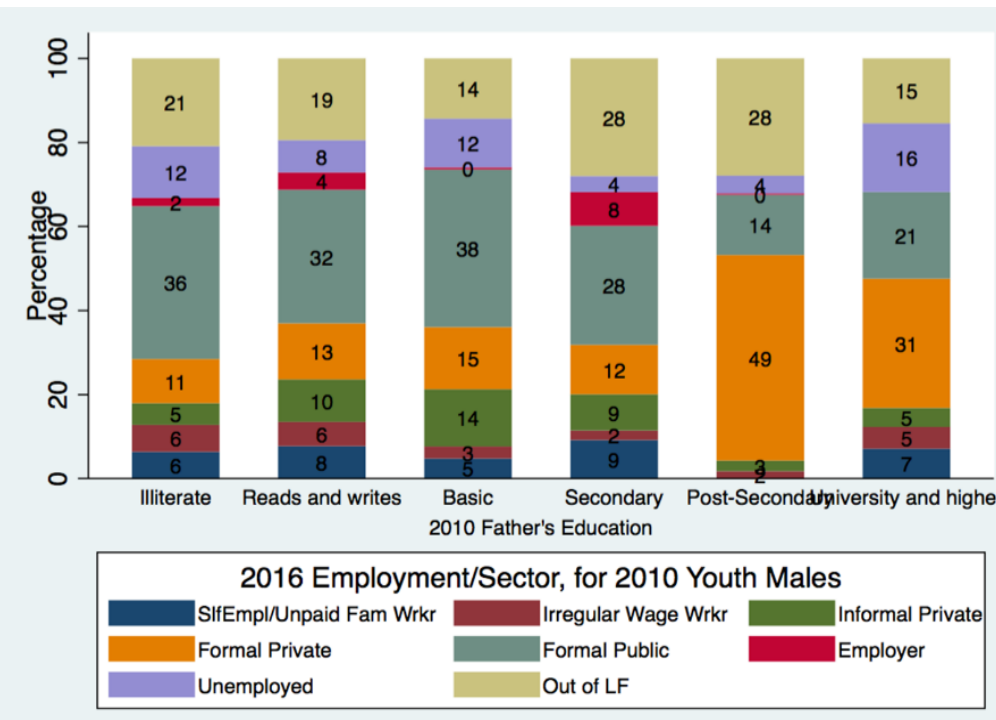

vii. 2016 employment by father's education in 2010, 2010 Jordan youth

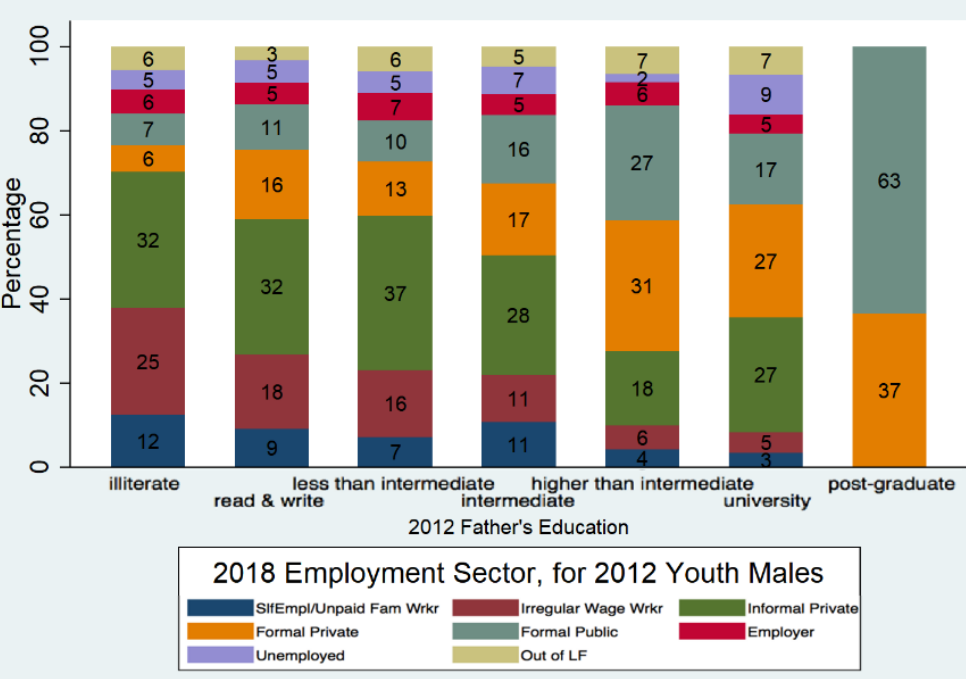

vi. 2018 employment by father's education in 2012, 2012 Egypt youth

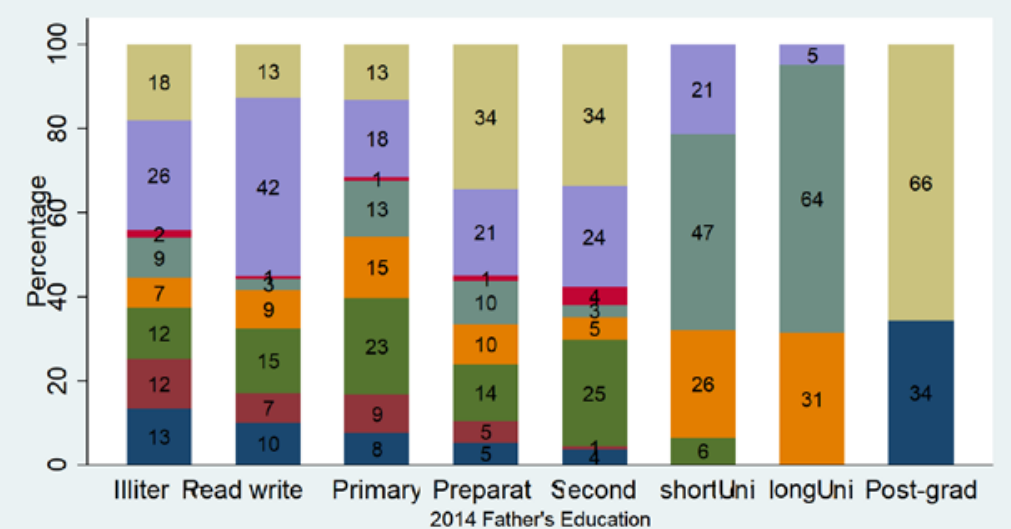

2014 Employment Sector, for 2014 Youth Males

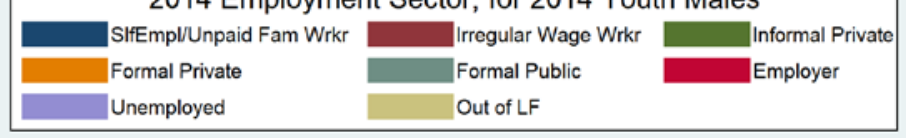

viii. 2014 employment by father's education in 2014, 2014 Tunisia youth

Source: authors' calculations based on ELMPS 1998-2018, JLMPS 2010-16, TLMPS 2014 (OAMDI 2019). 
Figure A6: Predicted probability of employment type by select demographic groups, Egypt 2006-18 (pooled)
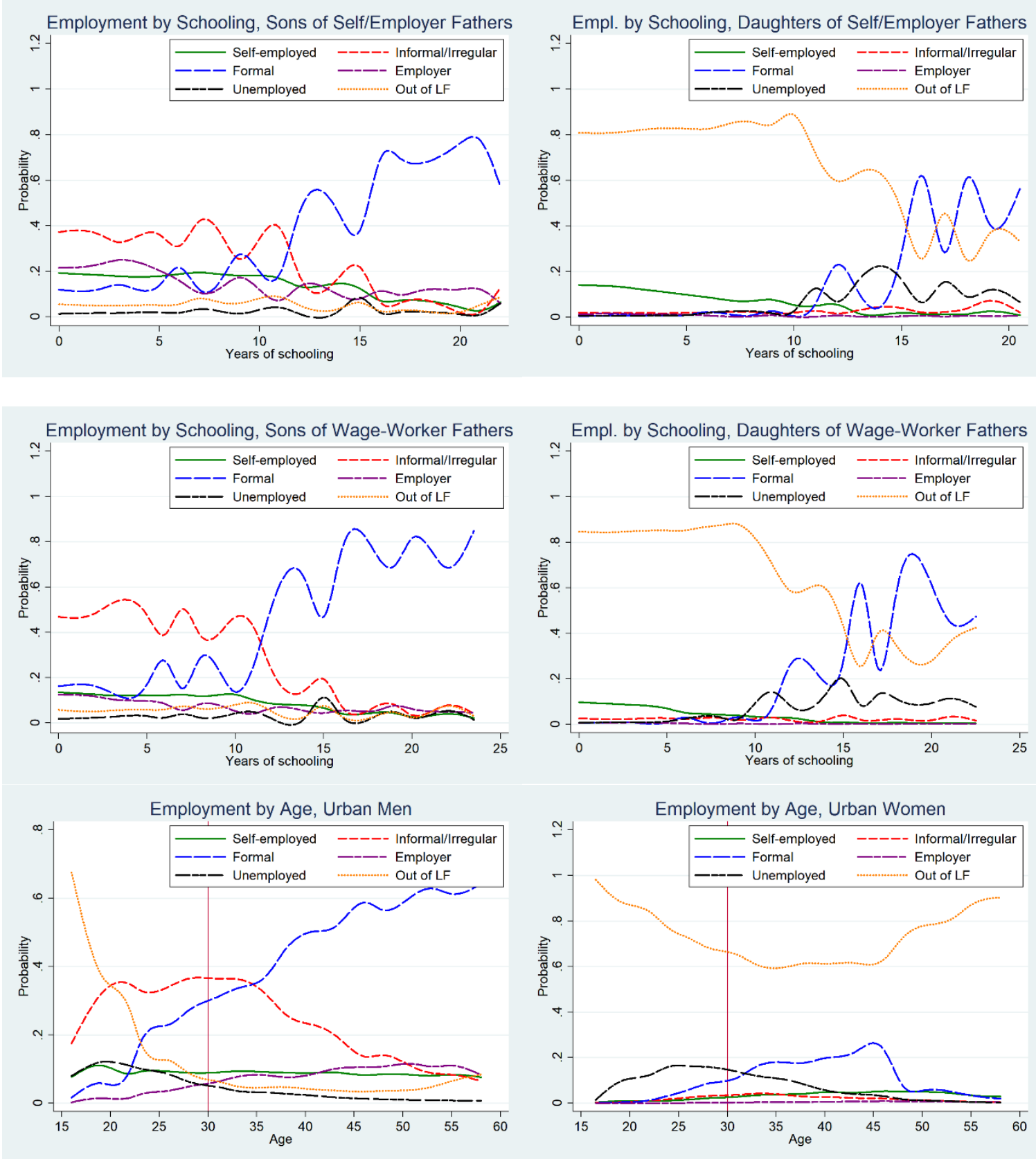

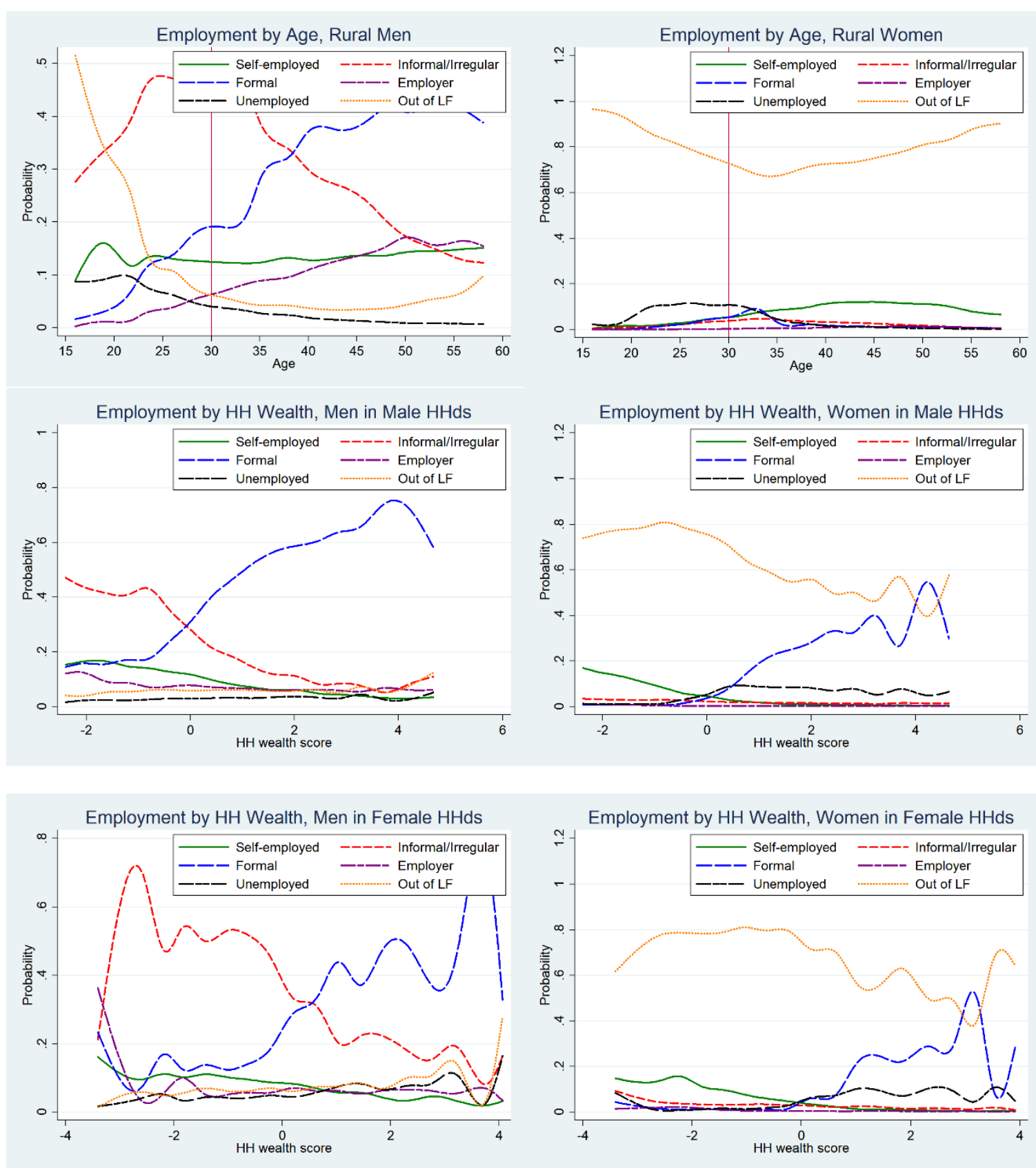

Source: authors' calculations based on ELMPS 1998-2018 (OAMDI 2019). 
Figure A7: Predicted probability of employment type by select demographic groups, Jordan 2016
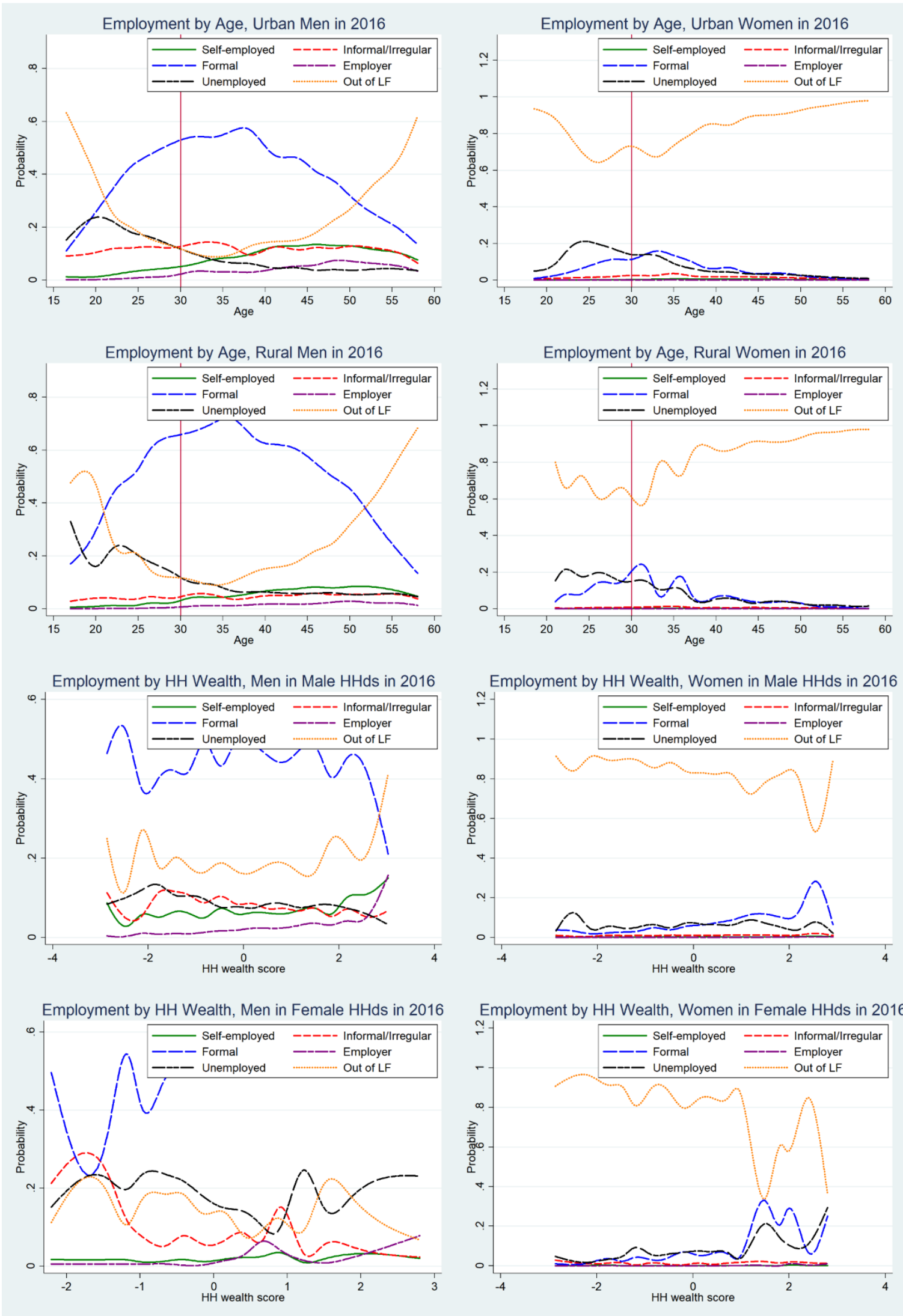

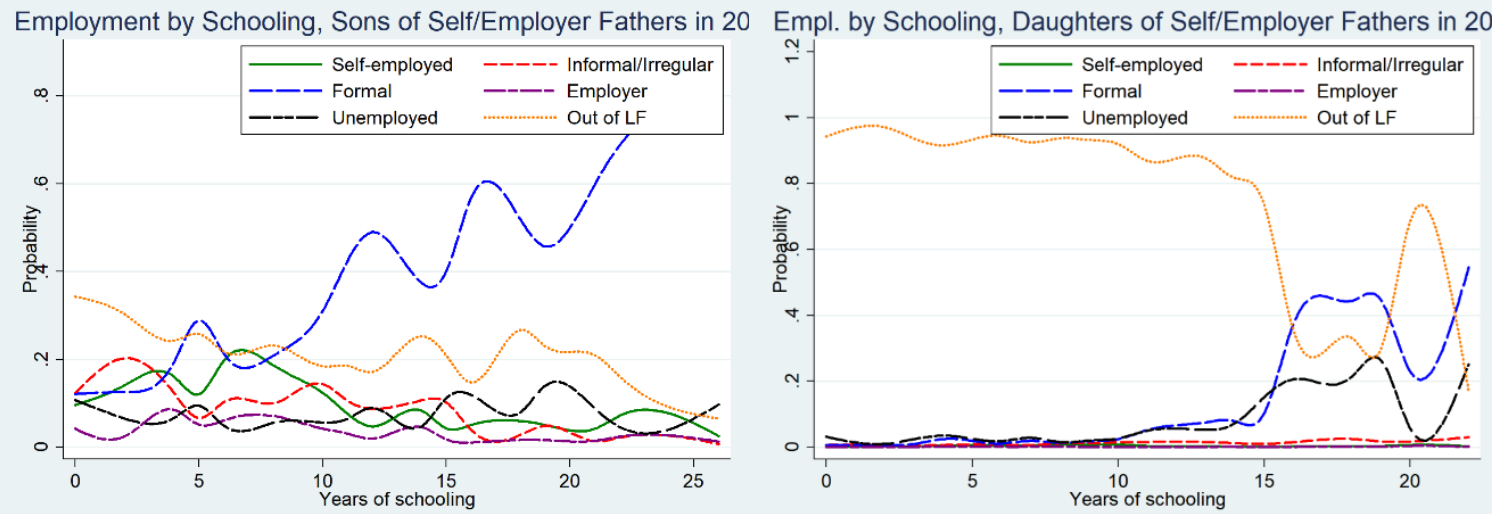

Employment by Schooling, Sons of Wage-Worker Fathers in 20 Empl. by Schooling, Daughters of Wage-Worker Fathers in 20.
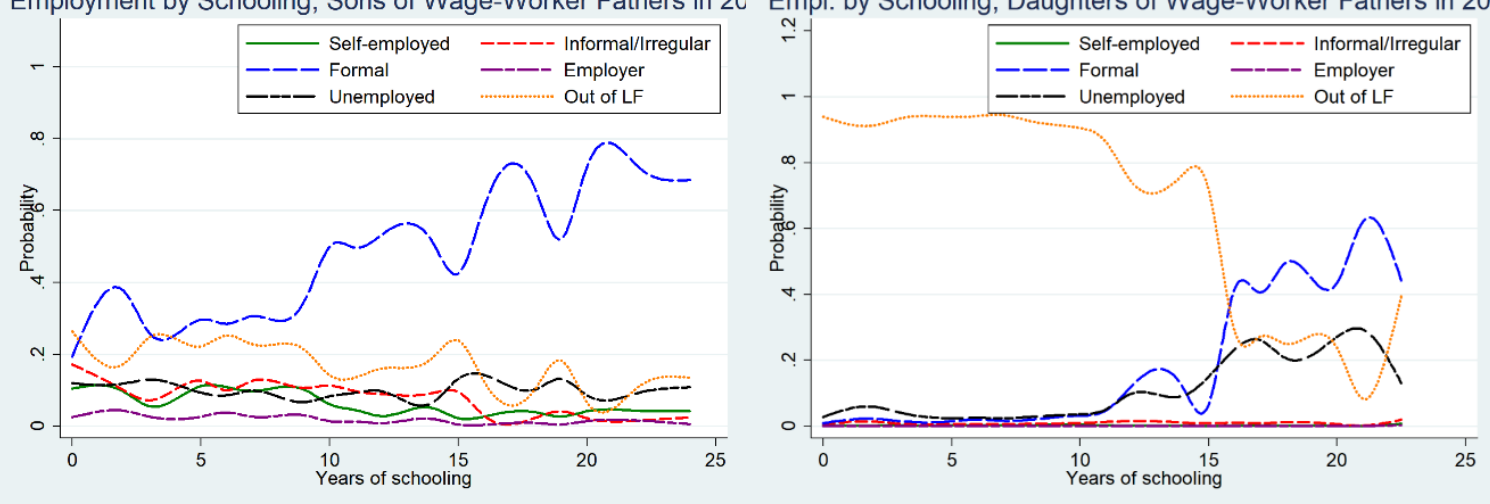

Source: authors' calculations based on JLMPS 2010-16 (OAMDI 2019). 
Figure A8: Predicted probability of employment type by select demographic groups, Tunisia 2014
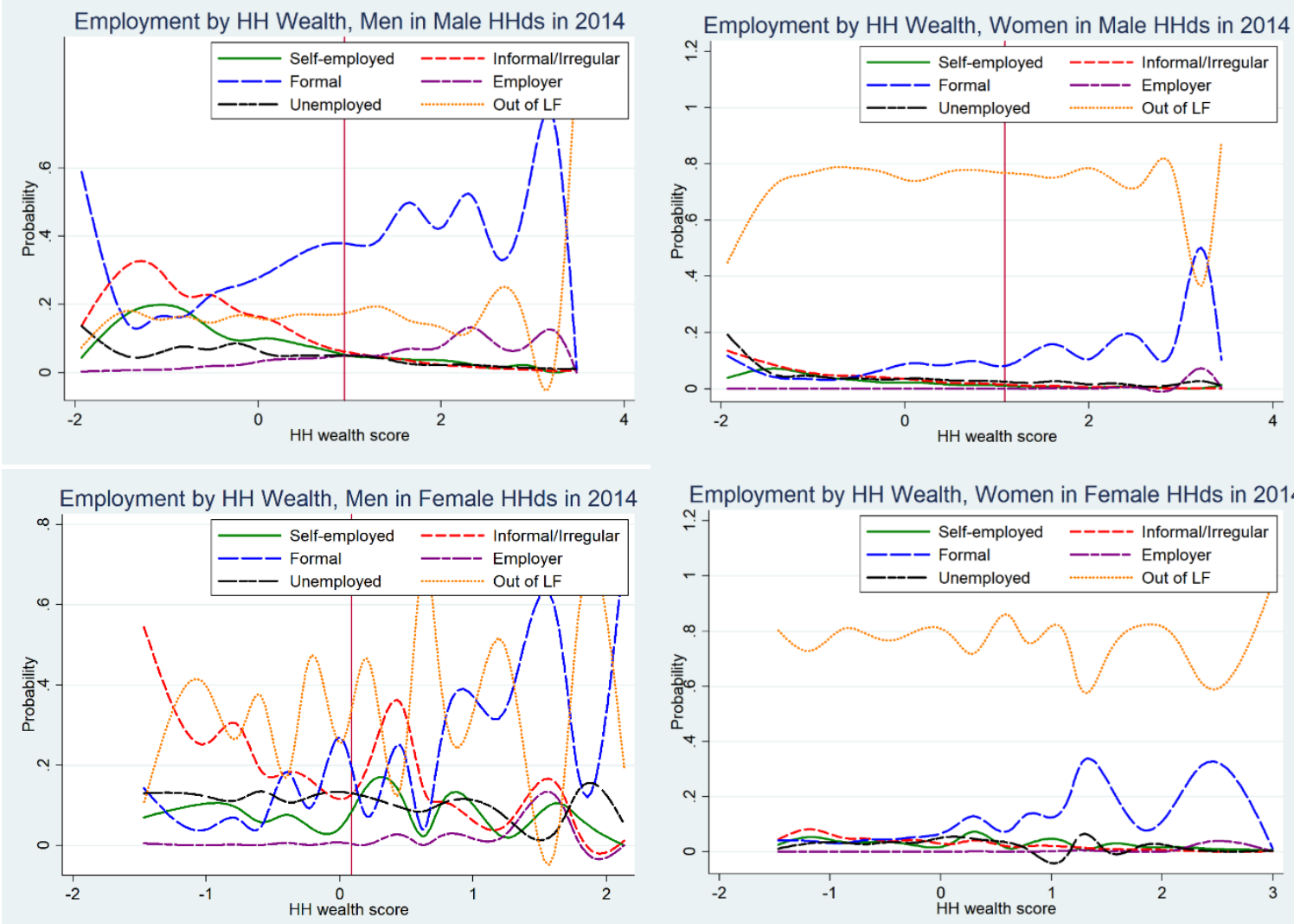

Employment by Age, Urban Men in 2014
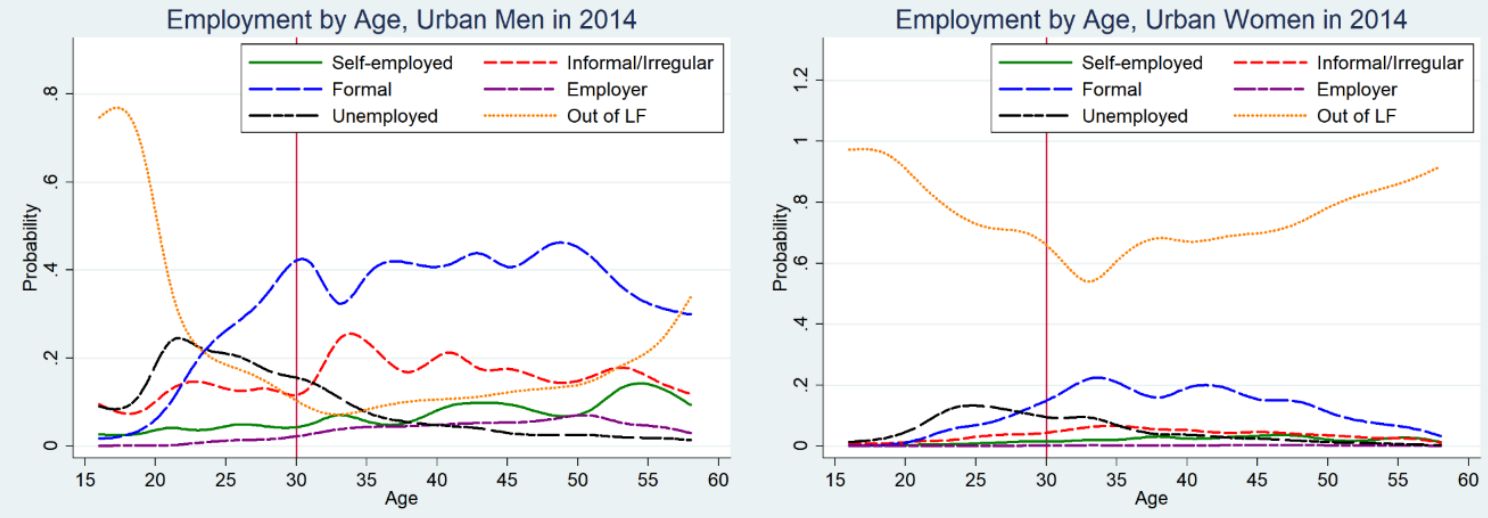

Employment by Age, Rural Men in 2014
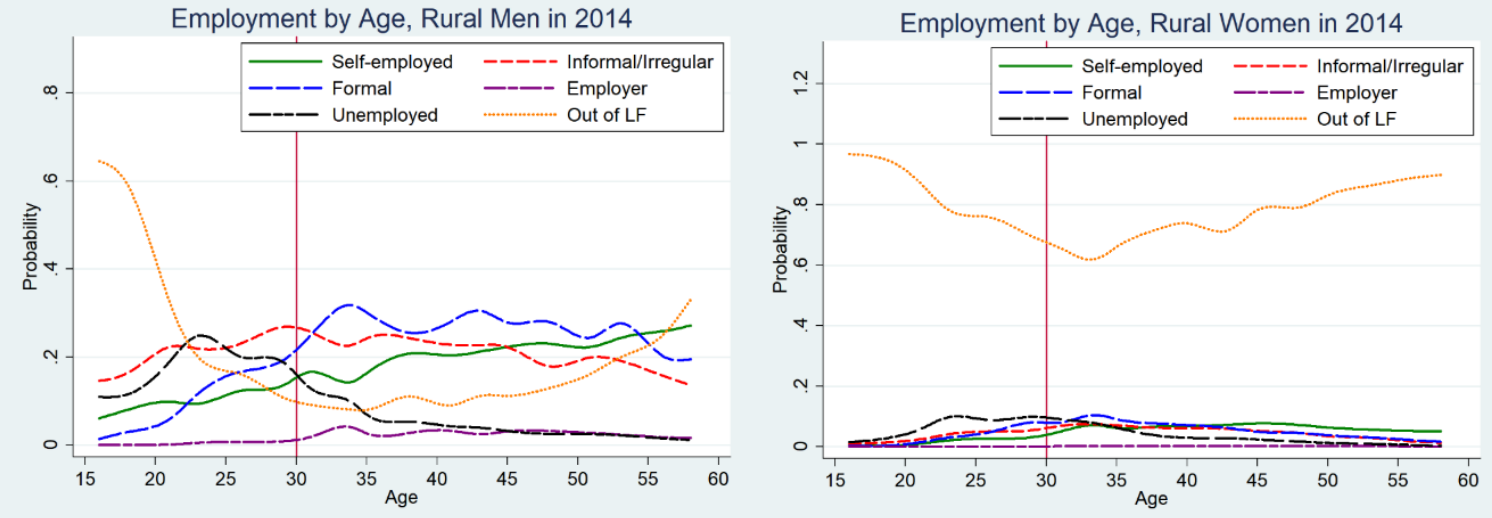

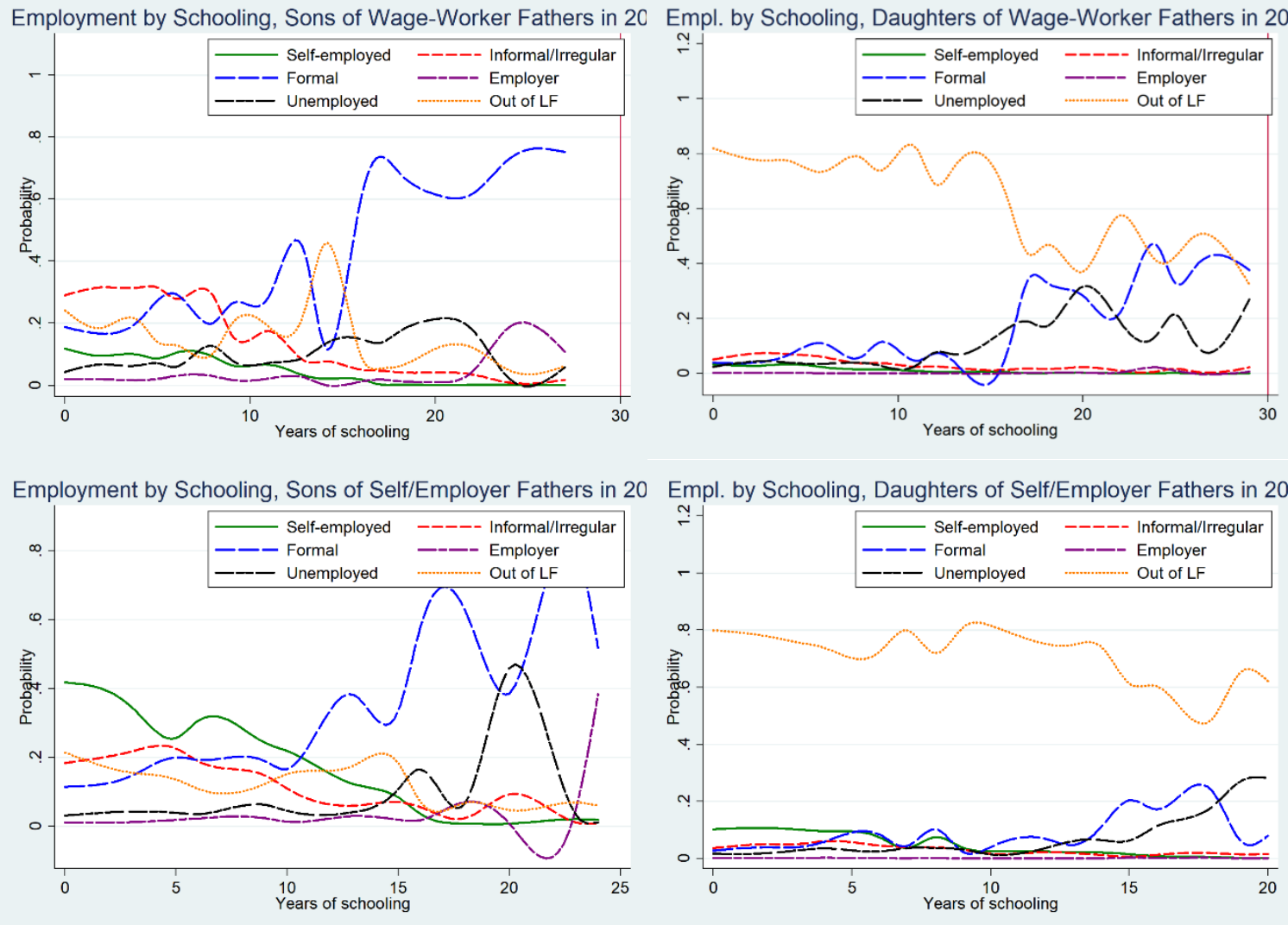

Source: authors' calculations based on TLMPS 2014 (OAMDI 2019). 